\title{
腎孟間接撮影法の研究
}

新潟大学医学部泌尿器科教室

(指導: 高安久雄教授)

新潟大学医学部放射線科教室

大学院学生 平田輝 夫

（指導：野崎秀英教授）

\section{STUDIES ON PHOTOFLUOROGRAPHY OF THE UPPER URINARY TRACT}

\author{
Teruo Hirata \\ From the Departments of Urology and Radiology, Niigata University \\ School of Medicine, Niigata \\ (Directors: Prof. H. Takayasu and Prof. S. Nozaki)
}

To detect the abnormal shadows of renal pelves and calyces in detail, the author applied a high-voltage photofluorographic technique to the upper urinary tract.

The photograms were taken by $60 \times 60 \mathrm{~mm}$ serial films using Toshiba X-Ray Apparatus KCD-12F type with rotating anode tube and indirect X-Ray Canon Camera. Some 10 serial films in a patient were taken at $120 \mathrm{KV}$ and $70 \mathrm{~cm}$ distance.

Films of 63 cases were examined, which consisted of plain films of the abdomen (10 cases), intravenous urograms (17 cases) and retrograde pyelograms (36 cases). And the results are follows:

1) Owing to the high-voltage photofluorography, bony shadows and intestinal masses became faint without any enema, evacuant or diet restriction.

2) Because of serial photography, stereographic observation was possible when the position was changed gradually.

3 ) On the intravenous urograms, if the kidney function normally, the calyces and pelvis were visualized within 2-3 minutes after the injection in the supine position. When the patient took upright position, the media were excreted from the pelvis immediately.

4) On the retrograde pyelograms, so-called "emptying times" of the each calyces and the pelvis in the normal kidney were studied. The times of the upper, middle and lower calyces and the renal pelvis were less than 5 minutes, 4 minutes, 5 minutes and 3 minutes in supine position and 2 minutes, 4 minutes, 4 minutes and 3 minutes in upright position, respectively.

5) Photofluorographic changes in 16 cases of essential renal hematuria were dilatation of renal pelvi-calyceal system $(68.7 \%)$, reflux of media from renal pelvis to calyces (43.7\%), Narath's symptom (43.7\%), movable kidney (31.2\%), flexion of ureter $(31.2 \%)$ and sustaind small shadow in one calyx $(18.7 \%)$.

6) Photofluorographic changes in 14 kidneys of nephroptosis were flexion of ureter (100\%), dilatation of renal pelvi-calyceal system (71.4\%), Narath's symptom (64.2\%), rotation of the kidney (50\%) and reflux of media from renal pelvis to calyces $(21.4 \%)$.

\section{I 緒 論}

泌尿器科領域に於けるレントゲン検查法は尿検查法, 䧛胱鏡検査法己並んで日常の診察から1日こして久かす 事の出来ない大切な検查法である.

レントゲン検查法が泌尿器科領域正り入れられたの は歴史的にみて比較的早く, 1895年レントゲン線発見の 翌年, Guyon によつて尿路結石症の診断に始めて用い られている. 次で1906年 Voelcker and Lichtenbergは
尿管カテーテルを用いて逆行性腎孟撮影法に成功し, 泌 尿器科的検查の新分野を開いた。 それ以後約 17 年間, 排

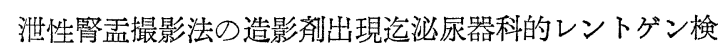
查法には大きな進歩が見られず，1923年 Mayo Clinic の Rowntree 等は 大量のヨードナトリウムを静脈注射 及び経口投与して, 尿路のレントゲン撮影に成功してい る.これが排泄性书盖撮影法の始めこされている。次で 1924年 Rosenstein and Lichtenberg, 又同年 Volkmann, 
1927年 Lenardouzzi and Pecco はこの方法に追試を行

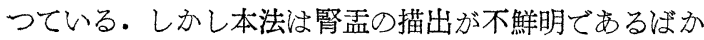
りか, 大量の造影剤であるョード郕の副作用のため実用 的でない事が分り，その後多くの研究者により造影唷の 改良がなされ, Binz and Räth により比較的毒性の弱 い，尿路の描出の良い造影剂が合成され，1929年これに よる尿路撮影のかなり良い成績が報告されている。そし て Lichtenberg and Swick が各種腎疾患の診断にこれ を用いて尿路撮影を試み，かなり優れている事を述べて いる11. 以来, こ>30年間に科学惊めざましい発展学已 げ, その結果, 光学器械の改善, レントゲン裝置, フイ ルム, 造影抄等が改良されて, 腹部単純撮影法, 静注 性腎孟撮影法 (以後 IVP 上略す.) , 逆行性腎孟撮影法

（以後 RP と略す））以勿論の事, 乙の外, 腹膜後腔 気体撮影法, 断層撮影法, 拡大撮影法, 動態撮影法, 尿 路血管撮影法, レ線佒畫撮影法等の新しい撮影法が行わ れるようになつた。更に最近に至つては，レ線をテレビ に応用した方法等全くめざましい発展をとげて来た。特 そレ線映畫撮影法やテレビを用いた撮影法注常に運動し ている上部尿路の観察に注最む適して括り，目的にかな つた方法と云えるが，とれらの裝置はいずれも高価であ り，でこでもすぐこれを利用出来ると云う訳には行か ず，ごく限られた所で利用されているにすぎない。

腎杯, 腎孟及び尿管の如く運動性を有する臟器の状態 をレントゲン学的に，てれら立体的に観察するために 致ごうしても撮影枚数にあまり制限の無い事が要求さ れ, しかも枚数が増加しても経済的に高価でない事, 更 飞被曝線量が撮影枚数に比して少い事等が要求されて来 る. 著者はこれらの条件を满す高圧間接撮影法を上部沓 路撮影法に試みてみ充。

\section{II 交献的考察}

間接撮影法は1895年 Röntgen がレントゲン線を発見 した年に彼自身がこれを試みたと云われている. 1896 年 Batelli-Garbasso の間接撮影に関する記載があり, Bleyer もとれ学 Photo-fluoroscope と名付けている2). 以来, 間接撮影法恀諸家により研究され発達をして来た のであるが, 主に間接撮影の性質上, 肺の集団検診とし て利用開発がなされ，1937年古賀33發，1938年 De Abreu $\mathrm{u}^{4)}$ が始めて肺の集団検診に用いて以来主に胸部撮影に 応用されて来たが，最近胃の集団検診，螢光倍增管を利 用したレ線映畫撮影法に応用されるようになり, 間接撮 影法も各分野に渡つて利用範囲が広くなつて来たのであ る.

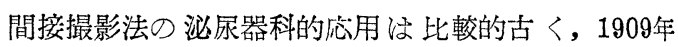
Lichtenberg が仰臥位に於ける膀胱の連続間接撮影法 を試み，本邦に於いては1938年三矢・田村占のし線映畫 撮影《よる排尿運動の研究，1954年高安等 ${ }^{6}$ の膀胱レ線 像の研究, 1956年岡・後藤")の間接レ線連続撮影法によ る上部尿路の排泄状況に関して研究報告したもの, 1957 年浅井 ${ }^{8}$ 沙螢光倍增管 使用して射精運動を報告し, 19 61年須山 ${ }^{9}$ 流これを利用して上部尿路の運動学レ線映畫 に招さめて観察している．更に同年，後藤等 ${ }^{10}$ ほオデル カ・ミラーカメラを用いて尿路撮影を行つている。ての オデルカ・ミラーカメラ注鏡写真機を用いて撮影する間 接撮法であつて，かなり鮮明な像守描出している．以上 述べて来たてれらの間接撮影法はいずれも低圧による撮 影法であるが，著者はレンズ写真機蛕用いて間接撮影法 を高圧で行つてみた。そして高圧の利点を生かし，実用 に充分供し得る鮮明なレ線像を得る事が出来た.

高圧撮影法は従来行わ机ているょりも高い管電圧, 即 ち $100 \mathrm{kV}$ 以上の電圧を用いる撮影法で, 主として胸部 撮影に応用され発達を見て来たのであるが，軟部組織を 主体とする泌尿器科領域には周团組織との間にコントラ ストにあまり差の無い事から殆んで利用されて来なから Te.

高圧撮影法 は 1924 年 E. Weber ${ }^{11)}$ が 笑效電圧 $90 \mathrm{kV}$ 及び治潦用レントゲン線管球を用いて $130 \mathrm{kVp} て ゙$ 胸部 撮影を，1925年 Zacker ${ }^{12)}$ が $100 \mathrm{kV}$ で， 1929年:Steph

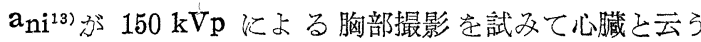
動く臓器学短時間で撮影しょうという考えから始まつて いる. 本邦に於いては1955年江藤 ${ }^{14}$ が深部治潦裝置学用 いて胸部学 $160 \mathrm{kV}$ の高圧で撮影老試み, 以後数多くの 報告がなされているが，てれらは主として胸部撮影に関 するものが多い. 次で食道, 胃等の撮影, 小焦点の撮影 が可能であるため拡大撮影への応用, 被曝線量の減少, 透過力の增大と云了性質から撮影時間の短縮, 血管心臓 造影法, レ線映畫への応用, 最近では間接撮影とくに胃 腸の集団検診にも利用されている ${ }^{15)}$.

更に障害陰影を少なくし得る点で断層撮影や，迴転横 断撮影飞用いられ，その応用範囲が広まつて来た。

高圧撮影法の泌尿器科への応用は, 前述せる如く, 軟 部組織を主体とする関係で周囲組織との間にコントラス 卜にあまり差の無い高圧は不利とされ，殆んご応用をぬ なかつたのであるが，1959年梶田 ${ }^{16)}$ は前立腺撮影法に $140 \mathrm{kV}$ の高圧を用いて障害陰影こなる恥骨の消褪で， 高圧撮影による利点を報告している。 
静注性腎孟撮影法は腎の造影成の排泄状態, 上部尿路

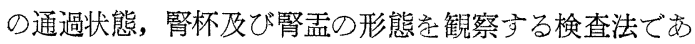
るが，圧迫帯定使用すると，上部尿路が幾分搪張して造 影され，腎の自然の姿をとらえるに注無圧迫による撮影 が好ましい.しかし無圧迫では造影剤が流出し，それ丈 腎杯，腎孟の造影が惡い。無圧迫腎孟撮影法に関して は 1956年藤井 ${ }^{17}$ 洁頭低位 20度にして 45 回撮影して $82 \%$ に大体満足すべき結果を得, 更に下部尿路の描出が出 来る場合も多いと述へ，翌年河㠃，福村 $\left.{ }^{18}\right)$ 訬 76\% ウ口 グラフィンによるIVP の成績字発表し, 撮影体位, 時間等に就いて検討を加え, 腎機能正常なら20度頭低 位, 注射後10〜15分撮影で最も鮮明な腎孟像が得られ をと報告し，更に尿管も鮮明に描出し得たと述べてい る. 又最近はこのIVPを撮影するにあたり，腎機能を みる目的で，造影剂学比較的早く静注する所謂“rapid pyelogram”を行つたり, 又逆に撮影時間を延長して撮 る “delayed pyelogram”, 又一定時間後, 更に造影郕 を追加して目的とする部位の描出を行う second injection㳊よる pyelogram 等, 色々己工夫され臨床に応用 されている. Kaufman et al. ${ }^{19}$ は造影剂30cc 平均 41 秒で 静注し， 2 分， 3 分，5 分及び routine 910 分, 15分之計 5 枚の撮影を行つて, rapid pyelogramによる 腎杯及び腎㙉の造影剤出現時間をみている. 岡等 ${ }^{200}$ delayed pyelogram 39 例に行い, routine の15分後 に至るも腎盐像を得られなかつた 9 例々 30 分後に撮影を 行つたら 8 例に於いて依然として像が無く, 书機能の有 無を見る目的で45分，60分，90分，120分，160分及び 180分の delayed pyelogram 学施行し, 一般に造影剂 注射後45分高タ60分の撮影で充分目的姿達し得る事学述 べ, Sigel ${ }^{211}$ は Spätaufnahme 更に延長して注射後 300分, 480 分に撮影を行つて, 本法の利点を報告して いる. Wilson et al. ${ }^{22}$ 怡 IVPを行うさい, 造影用学 一定時間後追加して上部尿路を明膫飞描出しょうと云う 陚みから最初造影剤を注射してから15分〜17分後に更に 造影剤の追加即ち second injection 学行い, 最初の注 射で得られた像よりも鮮明な像の描出に成功している.

レントグン検査法ではレ線の被曝はさけられないもの であるが，出来る丈とれを少くしなければならない，間 接撮影法では直接撮影法に比べて同一部位の撮影飞数倍 以上のレ線量安必要とするので, 患者の被瀑量梳一層問 題となる.特に泌尿器科領域では生殖腺が問題となり, 若年者を撮影する場合には遺伝的な立場からも充分にこ れらを保護する必要がある. 間接撮影では同じ黒化度 を得るに必要な $\mathrm{mA} / \mathrm{S}$ の少い高圧撮影を応用しないと
患者の被曝量は相当大になるとつで胸部撮影を例に己 つて実際的な数值を用いて被曝量をみてみると, 勿論, 被曝量はレントゲン発生裝置, 焦点被写体間距離, フイ ルター等によつて異るが，1枚の肺の直接撮影では 0.05 $\sim 0.12 \mathrm{r}$, 間接撮影では $0.3 \sim 0.7 \mathrm{r} て ゙$ 約 7 倍, 又消

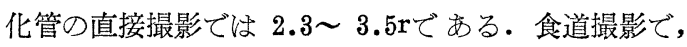
特に最近レ線被曝量の少い螢光倍増管の使用による万法 では管電圧 $110 \mathrm{kV}$ 高圧, 管電流 $3 \mathrm{~mA}$, 焦点營光板距離 $80 \mathrm{~cm}$, フイルター $1 \mathrm{mmAl}$ で, 患者の背部で $13 \mathrm{r} / \mathrm{m}$ と従 来の透視と同程度の線量である.胃間接撮影でこれをみ てみると，堀 ${ }^{23)}$ とれ海管電圧 $85 \mathrm{kVp}$ ，管電流 $120 \sim 1$ $50 \mathrm{~mA}$ 焦点螢光板距離 $80 \mathrm{~cm}$ の 6 回の 撮影で被検者の皮膚 線量は 9.2r, Roach \& Wigh 等 ${ }^{24)}$ ではそれぞれ 6 回の 撮影で 3 〜 12 及及 び 4 〜 $12 \mathrm{r}$, 牛田 ${ }^{25)}$ のレ線映畫による 膀胱撮影では管電圧 $60 \sim 65 \mathrm{kVp}$ で $2 \mathrm{~mA}$, 正面位で4.8〜 $8 \mathrm{r} / \mathrm{m}$, 斜位 で75 $80 \mathrm{kVp}, 3 \mathrm{~mA} て ゙ 12 \sim 14 \mathrm{r} / \mathrm{m}$ であ り, 安全最大皮膚線量は20〜25r である.1958年 Bodner et al. ${ }^{26)}$ ほ Lusted \& Miller ${ }^{27)}$ 々同様レ線肌慧の 被検者のレ線皮膚線量を20２5r にとどめるべきと云つ ている. しかし生殖腺に対しては更に少く，3〜10r され ${ }^{28)}$ ，乙れを越える場合は勿論，越えない場合でも撮 影にあたり，乙れら保護する必要がある。この事に関 し $\mathrm{Amar}^{29)}$ も何時, 如何なる場合でもレントゲン撮影 に亦たり，生殖腺を保護すべきだと述べている・レント ゲン撮影を映畫で撮るとどうしても一定時間レ線を連続 して暴射しなければならないが，著者の用いた間接撮影 裝置はフイルムの巻取とレ線曝射を連動させ，瞬間的な レ線曝射を繰返亦形式になっているので一定時間連続し て曝射するょりも被曝量は少くてする，1枚の撮影にあ たり瞬間的に $1.2 \mathrm{r}$ 曝射され, 最高に撮影を行つた12枚 で14.4r であるが，必ずしも12枚撮影をする必要はな く, 症例によつては $6 \sim 8$ 枚の撮影で充分である.この 被曝線量だと殆んぞ問題にならないが，しかし直接撮影 己比較するとやはりかなり多い量になる.

最近のオデルカ・ミラーカメラなごの連続間接撮影法 もやはりフイルムの巻取とレ線曝射を連動させ, 瞬間的 にレ線を出すようになつているが，20４0枚の撮影とな るとやはり問題となる. 明るいミラーカメラの使用によ つてもやつと直接撮影に比べ 1 枚の撮影飞要する被曝量 が $3 〜 5$ 倍程度に改善されたにすぎないと考えられる ${ }^{2)}$. 以上の事からも分る如く, や以り被曝量の事を充分 考慮に入れて撮影すべきであつて, 必要以上にレ線定曝・ 射してはならないと思われる。 
レントゲン学的に描出された腎杯, 腎孟の形態怔正常 人に於いても個人差が甚だしく，乙の形態的分類につい ては種くの説が研究者によつてなされている。腎杯，腎 瑥の形態はまず解剖学的に分類されているが，てれ更 そレントゲン学的に分類したのは1915年 Braasch であ る.その後 Marion, Papin, Joseph, Lichtenberg 及び Lauber 等の分類 ${ }^{11}$ があり，本邦では山之内 ${ }^{30)}$ 文び㖘 ${ }^{311}$ 等の分類がみられるが，特に Lauber 及び山之内のもの は極めて詳細に渡つている. 又仁平 ${ }^{32}$ は解剖学的筒盂の 大きさ及び大小腎杯の分岐状態を基にして正常腎孟像を 2 大別している. 即与 I 型) 解剖学的腎孟定認めるも の. II 型) 解剖学的腎孟沙認め難 $く$, 尿管より直接大腎 杯に分岐している感のあるもので，I 型山更にa腎盖よ り 2 〜 の大腎杯が分れ, 夫心から小腎杯が分岐し, 比 較的腎杯の分岐度の高いもの，b)大腎杯の分岐は認め難

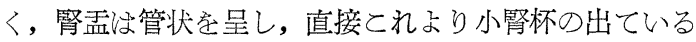
もの, 即ち筲杯の分岐度の低いもの及びc)腎瑥は大で囊 状を呈し，とれょり直接小腎杯の出る所謂アンプーレ型 のものと分類している. そしてI型の $\mathbf{a} か ゙$ 最も良く, 次 で b, c の順となり，II型が甚だ少いて述べている. 又 小腎杯の数怡極めて多様であつて，山之内によると最少

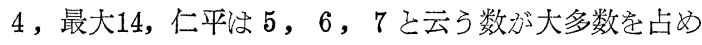
る己報告している。

殾杯，腎孟の運動状態をレ線学的に観察した報告注多 く, 1940年 Narath $^{33)}$ 《重複撮影を行つて腎杯括約筋 の運動を観察し，1930年 Jona \& Flecke ${ }^{34)}$ はP R

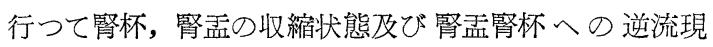
象を及ている. Alken u. Büschner ${ }^{35)}$ 汸上部尿路の運 動定レ線連続像で観察し, Maintz et al. ${ }^{367}$ 注動態撮影で 上部尿路の運動をみ, 本邦では山口 ${ }^{37)}$ がレ線連続撮影法 により腎杯, 腎孟の観察を行い, 岡, 後藤 ${ }^{7}$ 治間接レ線 連続撮影法により上部尿路の排泄状況学研究している. 最近に至り䖵光倍増管の出現で, これら上部尿路をレ線 明畫に撮影し, 排尿状態を詳細に観察出来るようになつ た.

RP は直接造影剤を尿管 カテーテルょり腎㙉内に注 入してレ線写真を撮影する方法で IVP よりも鮮明な腎

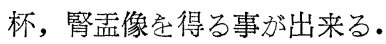

腎盐腎杯门の逆流現象は 主としてこの RP 像で多く 観察されるが, Catel \& Garsche ${ }^{38)}$ によれば正常腎の IVP像でもこ机似た現象がみられるると述べている。

・腎㙉腎杯への逆流現象乞は一度造影された腎杯像が消失 し, 或時期に再度造影される現象を云うのであるが, 病
的所見ではなく，正常雨㲹も時折見られるものである。

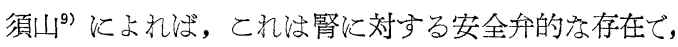
謷孟内圧の上昇豆調節するものであると述べている。

腎杯, 腎孟内に注入された造影剂の消失時間, 所謂 “emptying time”関する報告は諸家によつて多くな されているが, 主に遊走腎の検查法の1つとして研究が なされて来た。これを始めて正常人に行つたのは1921年 Goldstein $^{39)}$ によつてであり，彼によると3〜 7 分て筒 孟内に注入された造影剂怔消失すると云われ $\mathrm{O}^{\prime}$ conor $^{40)}$ 注 $6 \sim 8$ 分, 10 分以上を病的飞し, Dodson ${ }^{41}$ 性 5 分で空虚となるが，10分では必ず空虚己なる己述べ， Peirson ${ }^{42)}$ は正常で注 9 分後に空虚になり，た之え尿 管等に屈曲像が市つてもとの emptying time が正常 なら，この屈曲は大したものではないと断言出来ると 云つている. 須山 ${ }^{97}$ 㳂卧位10分, 立位 5 分以内を正常 範围として病警の尿路内停滞に就いて比較する資料 そしている. Lowsley \& Kirwin ${ }^{43}$ 柱異常血管, 線維 性癒着或怡他の原因による尿管屈曲と亦狭窄の有無を 知る上に有效であると述べ, 特に遊走腎又篎孟の搪 張による尿の流出状態を知るのに有效な検查法であると 云つている・しかしこれら emptying time は注入造影 鼡濃度, 注入速度及び注入量等により幾分異つて来る し，又体位が立位，半坐位及び仰臥位によつても異つ て来るものであり，乙れら諸家の報告例から大体10分以 内が正常範囲内己思われる.1962年森永 ${ }^{44)}$ 没遊走腎42例 の emptying time 学測定し, 注入後10分以上学病的已 し，42例中 26 例，61.9\%に遅延例安及，南 ${ }^{45}$ 访遊走腎者 20例を調べ10分以上残つていたものは14例，70\%であつ たと報告している・森永によるととれらの遅延渻の下 垂と余り密な関係が無く, 腎, 尿管の変化のうち尿管屈

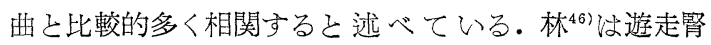
者の臥位, 立位のPSP 值と筲孟排泄時間との関係学論 じ, 臥位の PSP 值及び立位時の変動吕ら或る程度遊走 腎の有無及びその程度を知る上飞役立てようと試みてい る.

特発性腎出血に関するレ線学的報告を文献的にみてみ ると1936年高橋 ${ }^{471}$ 注本症の腎孟像に逆流現象学登見する ととが多い事を指摘して扮り，1954年 MacMahon \& Latorraca ${ }^{48}$ は腎中の静脈とそれ《接する腎杯との間に 腎杯円蓋部で交通丸゙直接行われている事老述べ, Pytel $^{499}$ はこれらの静脈, 腎杯交通路を IVP で実証し, 3 例の特 発性腎出血者をてれらの交通路安含部分腎摘除術を 施行して治瘾せしめている。更に彼は腎杯周囲に稀薄な 壁を有する静脈洞を見出して, 腎孟内圧の上昇で腎孟, 
静脈逆流が起り，この薄い壁を通り静脈血腎盖流入と云 ろ型で腎出血が起る事を報告している.1957年仁平 ${ }^{322}$ は 本症の腎盂像の研究学行い, RP 正常腎 124 例に行 い，乙れそ特発性雨出血者 120 例の腎孟像とを比較し統

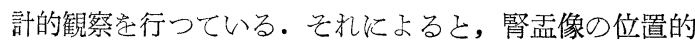
関係注, 篙出血例では患側が健側に比しや〉低く, 解剖 学的腎需の大きさは出血側がより大きいものが多く, 腎 下垂と腎出血との関係学述心゙，下垂は腎出血の原因の 一つである事を認めている，更に腎出血側では腎䀃外 溢流像の出現率が正常例のそれに比べて高い事も述べて いる. 同年清水 ${ }^{500}$ 注腎動脈撮影法を仰卧位，立位で比輍 し, 腎動脈に著しい下方変位と屈曲, 伸展等の変化を認 め, 静脈圧迫による䉤血性出血であろうと特発性腎出血 に対してレ線上から云つている. 1962年仁平 ${ }^{511}$ 過酸化 水素液々造影剤を混じて RP を行い, 出血病変部位に これが接触して発生する酸素の気泡群它腎孟像に描出さ せる工夫安している。しかし現在迄特発性筒出血症に特

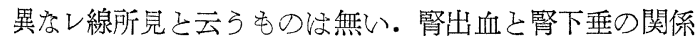
についてみてみると，腎が下垂する事により，尿管屈

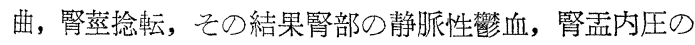
充進を来して督出血学すると考えられている. Spitzer ${ }^{52)}$

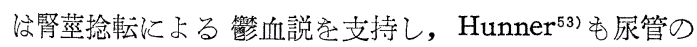
屈曲学認めている. Thelen u. Wiegers ${ }^{54}$ 沙腎下垂に上 り腎周困に変化を起し調節神経障害を来をし血尿学みる ものと考えている.

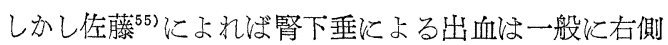
に多く, 特発性腎出血では左に多い己清水, 前川 ${ }^{56)}$ 々報 告している. Sharpe et al. ${ }^{57)}$ も左4, 右 1 で左に多 いと述へ，左に多いのは左の動脈の走行の変化による己 している. 又渡辺 ${ }^{58)}$, 北川 ${ }^{59)}$, 志賀 ${ }^{60)}$ 等も腎下垂による 腎出血例をみている.

腎下垂症をレントゲン学的に証明するには撮影にあた り，仰卧位像已立位像との比較をしなければならない が, 1906年 Voelcker u. Lichtenberg ${ }^{61)}$ は始めて RP の 研究を発表し, 立位に於けるレ線撮影の必要性を記載し た. 1910年 Fenwick ${ }^{62)}$ は臥位，立位による腎孟撮影法 を行い, その後 Reich (1921) ${ }^{63)}$, Thomas (1930) ${ }^{64)}$, Gottlieb (1933) ${ }^{65)}$ 等により 立位腎孟撮影法が行われ， 本邦では1920年井尻 ${ }^{66} か ゙^{6}$, 翌年佐谷 ${ }^{67)}$ が臥位, 立位腎孟 像に就いて報告し，立位で撮影するこ一層腎下垂が明瞭 そなること，及び病的状態では腎盖が第腰椎を越えて 下ること, 尿管の走行が 異常になることを指摘してい る.
1936 年清水 ${ }^{68)}$ ほ立位己臥位腎孟像安比較して最高 $11 \mathrm{~cm}$ の差を認め, 1955年吉川 ${ }^{699}$ は腎孟が縱軸迴旋すると己を 報告し，1956年大越等 ${ }^{70}$ 以腎下垂診断上の立位撮影の価 值を論じ, その中で倒立位に於ける監の移動を, 夫くの 位置に打ける呼吸性移動乞共に検討している.1960年清 水 ${ }^{71)}$ 腎孟が下垂する場合，単に下降するのみでなく， 縱, 横, 斜軸廻旋をする事を述べ立位の腎孟变形に関し 詳細に報告している。それによる己腎下垂症状は腎の下 垂度に一致せず，下垂により起る腎莖捻転，尿管屈曲，

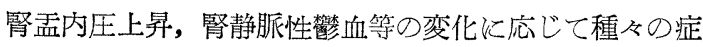
状が誘発され, 臥位, 立位の腎孟像を比較して腎孟像の 変化々自覚症状とが密接なる関係がある事を述べ, 立位 撮影の必要性学強調している.1960年 Gondos ${ }^{72}$ 渻

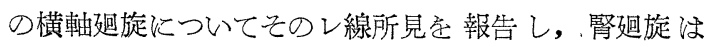
縱, 横及び前後軸のいずれかに起り,一般に 2 軸或々 3 軸が一諸になつて起つて来る事が多く，その中で特に 1 軸に強く現れて来る.そして横軸备旋のレ線写真の特徵 として, 腎陰影の縱径の短縮, 腎下極の鈍形, 腎杯系の 縱径の短縮及び腎孟尿管移行部の高在性等をあげてい る.この横軸迴旋は殆んで腎下極の前方偏位であつて, 腎下垂の場合もこの迴旋をする可能性があると述べ，レ 線撮影伛たり仰卧位，腹臥位及び側位撮影の必要性に ついても論じ, 横軸廻旋はこの側位像で良く描出され る. 翌年彼は腎の縱軸备旋に関する報告学している ${ }^{73)}$.

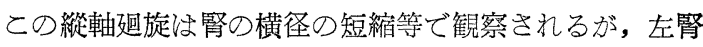
よりも右腎に多く，腎が下垂する場合，腸腰筋が下方に 向うにつれ解剖学的横断面が太く大きくなるので腎学側 方に偏位させて腎門が前方に向うように縱軸で迴旋する こ述べている．乙の迴旋が右腎に多い事から肝蔵が関係 していると云つている。仰臥位でみられた綎軸迴旋は腹 卧位で撮影する己一般にこの伵旋は減少し，或は消失す る事もあるので, レ線陰影で腎にかつる迴旋を認めた時 に注仰臥位, 腹卧位及び側位撮影を行つて比輘してみる べきだと述べている.1960年 Narath $^{74)}$ 渻下垂とそ の症状が下垂度とは必ずしも一致しないと云い，レ線撮 影を行了場合, 卧位撮影の後, 患者を撮影台より扣ろし て数回跳躍させたり，咳をさせたりして靔を下方に移動 し易くしてやる事が大切であると述べ，かつる方法をと らなければ腎はその部位にとざまり，下垂の可能性が㩊 される抢それがあると云つている。腎下垂の診断には腎 孟像が腰筋の辺縁に 接する所謂, Hutter 氏症状 ${ }^{75)}$ とか 腎盂像で尿こ造影滆との境にぼけた境界線が現れる $\mathrm{Na}$ rath 氏症状が非常に役立つと云つている. 又この Hutt- 
er 氏症状は水腎症の時にも屢と観察される所見で, 腎 孟の緊張が低下して囊状を呈する場合にか つる変化を己 ると云われている.1962年 Hajós ${ }^{76)}$ は IVP で連続撮 影を色々な体位で行い, 更に呼吸を变化させて卧位, 立 位の腎孟像を観察している，㛑は立位になると一つの反 射が起り, その反応として腎杯, 腎孟系に収縮が起りそ れらの内腔学狭める・しれが即ち腎臟の起立性反応已称 するもので，レ線学的にてれを観察している.卧位腎 杯，腎孟像怯比較的巾が広く造影されているが，立位で 注狭くなると述べ，143例の連続撮影でこの起立性反応 を調べて起立時の腎孟排泄状態をみて, てれは健康人で も種々であつて腎盎は時に全く排泄され何も残らない事

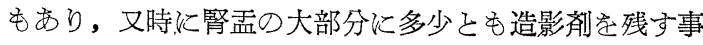
あある.そしてての起立性反応安 3 つの病型に分けてい

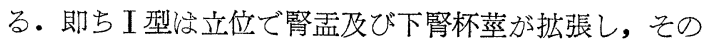
他の腎杯䒧は収縮している場合で，腎跙の緊張低下が疑 われ，腎下垂，腎の炎症及び膀胱疾患でもこの型が見ら れる事があり，II型は立位で腎孟の拡張，腎杯系全てに 搪張がみられるもので, 腎盎内圧の充進によるもので尿 管結石, 腎血管系閉塞, 尿管狭窄等の時にみられる. III 型は強直型と云われ，腎の炎症，長期に渡る腎孟内圧の 元進のため,ついに謷孟内壁に障害が及んだもので, 起 立性反応は消失しているか，又注無力状を呈する。

そして卧位の撮影で，腎杯及び腎孟に拡張像を認めた 場合にての拡張の原因が何んであるか，例えば狭窄等に よる器質的なものか或は腎盎の緊張低下によるものであ るかは臥位撮影の踈盂像のみでは鑑別が困難であり，と の起立性反応をみると大変役立つ事を強調している.

\section{III 撮影装置}

試作裝置は東芝 $\mathrm{KCD}-12 \mathrm{~F}$ 型で（第 1,2 図), 本裝置 注 1) 高圧撮影が可能である，2）蓄放式波尾截断型で 西る．3）回転陽極管球安使用している４）透視が出 来る.5）撮影台の倒立が容易である(第 1,2 注).

6) 操作が簡単であり, 小型で運搬が可能である等の特 徵を有している.本裝置は蓄放式であるため小電源で使 用出来る事, 電源の変動に影響されず, 波尾截断方式の 採用により写真効果上不用のレントゲン線の放出を防 ぎ, 被曝線量を少くし, レントゲン線管球の保護能率を 高め, 散乱線を少くし得るし, 次の充電時間を短縮出来 る利点もある. 又回転陽極管球の使用のため得られた像 の鮮鋭度が増し, 連続撮影の可能が容易である等の利点 もある.更に透視が可能であるため，あらかじめ透視を 行つて目的とする部位等を観察する事も可能で，透視を
しながら撮影する事も出来る・又撮影台の倒立及び被検 者の位置の移動等に電動式を採用しているため従来の如 く,まず仰卧位で撮影し，立位撮影の時別な撮影台に歩 ませてから撮影しなければならないと云うょうな不便は 無く, 被検者がその心 $>$ 位置で撮影台が第 1 図及び第 2 図の如く倒立するため腎孟排泄時間の測定，惄臓の起 立性反応の観察及び腎下垂の 検査等にも大変便利であ る.

\section{IV 撮影条件}

撮影条件は第1表に示すように, 使用管電圧は 115 $120 \mathrm{kV}$ の高圧を用い, 管球から螢光板迄の距離恪70 $\mathrm{cm}$, 螢光板 DPS, リスフォルム $8: 1$, カメラはキヤ ノン $\mathrm{F}: 1.5$ 間接撮影用, フイルムはフジ間接撮影用フ イル $60 \times 60 \mathrm{~mm}$ 長尺判を使用し，造影剤はＩＶＰ亿主と して85\%ウロコリン M, RP には60\%ウロコリンM使 用した。

\section{V 各種撮影法による自験例}

腹部単純撮影法10例, IVP 17例及 び RP 36 例の計63 例に高圧間接撮影法学試み，それぞれの撮影法による成 績について述べる。

1）腹部単純間接撮影法

第 1 表 間接撮影装置並びに撮影条件

\begin{tabular}{|c|c|}
\hline 装 置 & 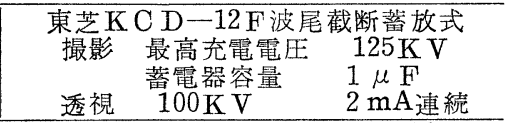 \\
\hline 管 球 & $\begin{array}{ccc}\text { 東芝 } & \begin{array}{c}\text { 口-タノード } \\
\text { 焦 点 }\end{array} & 2 \times 2 \mathrm{~mm}^{2} \\
\end{array}$ \\
\hline 使用管電生 & $115 \sim 120 \mathrm{~K} \mathrm{~V}$ \\
\hline 管球螢光板 & $70 \mathrm{~cm}$ \\
\hline 螢光板 & DPS \\
\hline $\begin{array}{l}\text { リスフォル } \\
\text { ム }\end{array}$ & $8: 1$ \\
\hline カメラ & キャノン $\mathrm{F} ：$ 1.5間接撮影用 \\
\hline フィルム & フジ間接撮影用フィルム $60 \times 60 \mathrm{~mm}$ 長尺判 \\
\hline 造影剤 & \begin{tabular}{l|l} 
逆行性 & 主として60\%ウロコリンM \\
静注性 & 主として $85 \%$ ウロコリンM
\end{tabular} \\
\hline
\end{tabular}

正常例 5 例, 右腎結石 2 例, 左腎結石 1 例, 馬尾神経 腫瘍 1 例及び右側腹部腫瘤の腹膜後腔気体撮影法 1 例, 計10例について本法を行つた.

i）撮影方法：被検者には下剂，食事制限及び浣腸 等の前処置は全く行わず，そのま〉撮影定行つた。撮影 条件は第 1 表に示す如くであり, 腎結石症では患側を下 
にして撮影台上で体位を $0^{\circ}, 30^{\circ} ， 60^{\circ}, 90^{\circ} ， 120$ $\circ, 150^{\circ}, 180^{\circ}$ と傾斜させて計 7 枚撮影し, 結石陰 影の形態を立体的に分析した. 又腹膜後腔気体撮影法で ほ腹膜後腔に酸素を約 900 1200cc注入して, 注入後一 定時間患者の上体を起して执いて撮影した。撮影体位は 全て仰臥位で行い, 必要に応じて撮影台上で第 III 第 $\mathrm{N}$ 斜位（第 3 図）にして角度を变えて撮影した。

ii）代表的症例

症例番号 5.K.Y, 55才, 女子. 正常例

管球電圧が $120 \mathrm{kV}$ の高圧であるため, 第 4 図に見る 如く, 腎部位に関係のある第11〜12肋骨の陰影がかなり 消煺していて腎部位の読影にかなり有利となつている。 しかし軟部組織である腎の輪郭ば不明膫であり読影する には不充分である。腸腰筋陰影も殆んご消褪し読影する 事が困難である. 骨陰影では, 肋骨や, 椎体の横乫起等 はかなり消褀していて，乙の事は前述せる如く腎部の読

第 2 表 腹部単純低圧直接像と高圧間揬像の比較

\begin{tabular}{|c|c|c|}
\hline & 低圧直接像 & 高圧間接像 \\
\hline 腎輪郭 & 明瞭 & 不明瞭 \\
\hline 晹腰筋陰影 & 明瞭 & 不明瞭 \\
\hline 11〜 12肋骨陰影 & 消褪せず & 消裉する \\
\hline 椎体横突起 & 消褪せず & 消裉する \\
\hline 腸内固形物 & 消失せず & 消失する \\
\hline 腸内ガス & や〉鮮明 & 鮮明 \\
\hline 前処置 & 必要 & 不必要 \\
\hline エントラスト & 良 & 不良 \\
\hline
\end{tabular}

影に有利であり，更に尿管の陰影観察にも有利となつて いる.しかし推体は尚かなり強く現れている.腸内容は 下剤投与, 食事制限, 浣腸等の前処置を行つていない が，かなり消裉し，読影に支障はないが，腸内ガスは明 瞭に周囲とコントラストをなして描出されている。

この第 4 四の高圧間接像と第 5 図の低圧直接像と气比 較してみると, 従来行われている低圧直接像の方が腎輪 郭や腸腰笳陰影が良く描出されていて軟部組織を主体々 する泌尿器科レントゲン検査法としては良いのである が, しかし目的によつてはこれら高圧の利点を生かして 充分臨床に役立つもの之思う。との高圧間接像已低圧直 接像とを比較して第 2 表に示すが, 以上の事が一層はつ きりするものと思われる。

症例番号 6. Y.I, 64才，女子.

主訴：右側腹部鈍痛

診断： 右腎結石症 (铸型結石).
撮影目的：本症例は routine の腹部単純撮影で右 側腎部位に鋳型状の結石陰影を認め, これの立体的棈造 を観察するために患者に撮影台上で体位を変えさせて本 法を試みてみた。との結石が 1 つの結石であつて, 互に 縱と横とにつながりのある鋳型結石なのか, 又は鋳型結 石の他に数コの腎結石が存在しているのか直接像の平面 的な写真 1 枚丈では結石の立体構造が分らない。そこで 著者はこの結石の立体構造を観察するために種々の角度 からこれを撮影してみた。

前処置：施行せず・

撮影体位及び枚数：最初仰卧位で1枚撮影し, 次に 右側をフイルムに接近させて, 左側が管球に近づくょう な体位, 即ち第IV斜位（第 3 目d学已らせ, 撮影台已被 検者々の角 $30^{\circ}, 60^{\circ}, 90^{\circ}, 120^{\circ}, 150^{\circ}$ 及び $180^{\circ}$ に変じて計 7枚撮影した。 $120^{\circ}, 150^{\circ}$ 沙第 I 余位 （第 3 図a)になる訳で $180^{\circ}$ は腹臥位に相当する訳であ る.

所見：第6 図は右腎結石の仰臥位撮影像であるが， この結石陰影飞は数力所, 濃い円い部分が認められる. この陰影が鋳型結石とは無関係に別に存在するものか, 又は連がりを有するものか，との1枚の写真丈では鑑別 する事が出来ない，そこで体位を第 $\mathbb{N}$ 斜位 $30^{\circ}$ となし撮 影してみるとこれら円い陰影は腎盐像にみる腎杯荎と似 たつながりを有する鋳型結石である事が分る.更に $60^{\circ}$

（第 7 园）に体位を変えてみると，この関係は一層明ら かとなり, 腰部腎変位の時に見る腎孟像と似た形になつ て描出されている.そして仰卧位像で濃く円い陰影とし て認められたもの腎杯中に存在せる結石で腎盎にある 結石と互につながつている事方分つた. 角度を更に $90^{\circ}$,

$120^{\circ}, 150^{\circ}$ と変じて行くとこの結石陰影は次第に形 態を変え, $150^{\circ}$ では第 8 図に示すような形になつてし まう. 以上種々の方向より角度を变えて腎結石の立体構 造の観察を行つたか， この結石は 1 個の結石からなつて いると云う考えに達し，乙れを後に手術的に確認した。

症例番号10. S.N, 65才, 男子.

主訴：右側腹部不快感

診断 : 右側腹部腫瘤

撮影目的：本症例访右側腹部に不快感があり, 某医 の下で右側腹部に可動性, 表面滑, 手拳大の腫留を指摘 されて来院せる患者で routineのレ線撮影で右腎下垂の 診断がついた例で右側腹部に触知された腫瘤は右腎であ る事が分つたものである・高圧撮影法では腸内容固形物 は比較的良く消裉するが，腸内ガス性明瞭に描出される 
第 3 表 10 例の高圧間接腹部単純撮影成績

\begin{tabular}{|c|c|c|c|c|c|c|c|c|c|c|}
\hline No. & 名 & 年 & 性 & 診 & 断 & 腎輪郭 & 腸腰筋 & $\begin{array}{l}\text { 腸内固 } \\
\text { 形物 } \\
\end{array}$ & 腸内ガス & 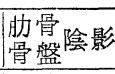 \\
\hline 1 & S. $\mathrm{F}$ & 45 & 우 & 正 & 常 & 不明瞭 & 不明瞭 & 消失 & | > 鮮明 & 消褪 \\
\hline 2 & Y. $\mathrm{K}$ & 42 & 우 & 正 & 常 & 不明瞭 & 不明瞭 & 消失 & 鮮明 & 消裉 \\
\hline 3 & K. K & 71 & $\widehat{\hat{O}}$ & 正 & 常 & 不明瞭 & 不明瞭 & 消失 & 鮮明 & 消褪 \\
\hline 4 & T. I & 33 & $\hat{0}$ & 正 & 常 & や>明瞭 & 不明膫 & 消失 & 鮮明 & 消褪 \\
\hline 5 & K. Y & 55 & 우 & 正 & 常 & 不明瞭 & や> 明瞭 & 消失 & や>鮮明 & 消褪 \\
\hline 6 & Y. I & 64 & 우 & 右婯 & 结石 & 不明瞭 & や> 明瞭 & 消失 & 鮮明 & 消褪 \\
\hline 7 & I. $\mathrm{K}$ & 48 & 우 & 右畩 & 结石 & 不明瞭 & 不明瞭 & 消失 & 鮮明 & 消褪 \\
\hline 8 & T. O & 35 & 우 & 左置 & 结石 & 不明瞭 & 不明瞭 & 消失 & 鮮明 & 消褪 \\
\hline 9 & E. $\mathrm{K}$ & 21 & $\hat{0}$ & 馬尾神 & 尘腫瘍 & 不明瞭 & や> 明瞭 & 消失 & 鮮明 & 消褪 \\
\hline 10 & S. N & 65 & $\hat{0}$ & 右側 腹部胴 & 留 (P.R.P) & 明瞭 & 明膫 & 消失 & 鮮明 & 消襚 \\
\hline
\end{tabular}

第 4 表 17 例の静注性腎孟間接撮影法

\begin{tabular}{|c|c|c|c|c|c|c|}
\hline No. & 名 & 年 & 性 & 診 & 撮影体位 & 造＼cjkstart影 \\
\hline 1 & M. M & 21 & 霖 & 常 & 仰臥位－立位 & $* 85 \% \mathrm{UM} 40 \mathrm{cc}$ \\
\hline 2 & I. $\mathrm{M}$ & 44 & $\hat{0}$ & 正 & 仰臥位 & $85 \% \mathrm{UM} 40 \mathrm{cc}$ \\
\hline 3 & H. S & 51 & $\hat{0}$ & 正 & 仰臥位 & $85 \%$ U M $40 \mathrm{cc}$ \\
\hline 4 & A. $\mathrm{K}$ & 52 & 우 & 正 常 & 仰臥位 & $75 \%$ UM $40 \mathrm{cc}$ \\
\hline 5 & Y. $\mathrm{Y}$ & 30 & 우 & 左腎出血 & 仰卧位 $\rightarrow$ 立位 & $60 \%$ UM $20 \mathrm{cc}$ \\
\hline 6 & U. $\mathrm{Y}$ & 31 & $\hat{0}$ & 左腎出血 & 仰臥位－立位 & $85 \% \mathrm{UM} 40 \mathrm{cc}$ \\
\hline 7 & T. $\mathrm{G}$ & 55 & $\hat{0}$ & 左腎出血 & 仰臥位 $\rightarrow$ 立位 & $85 \%$ U M $40 \mathrm{cc}$ \\
\hline 8 & S. $K$ & 61 & $\hat{0}$ & 右腎腫瘍 & 仰臥位 & $85 \%$ UM30cc \\
\hline 9 & H. M & 23 & $\hat{0}$ & 左腎結核 & 仰臥位 & $85 \%$ UM $40 \mathrm{cc}$ \\
\hline 10 & K. A & 24 & 우 & 左腎結核の疑 & 仰臥位 & $75 \%$ UM $30 \mathrm{cc}$ \\
\hline 11 & M. I & 30 & 우 & 右腎結核の疑 & 仰臥位，立位 & $85 \%$ UM $40 \mathrm{cc}$ \\
\hline 12 & S. $Y$ & 24 & $\hat{0}$ & 右腰部腎変位 & 仰臥位 $\rightarrow$ 立位 & $85 \%$ UM $40 \mathrm{cc}$ \\
\hline 13 & O. $\mathrm{H}$ & 22 & $\hat{0}$ & 腎孟腎炎 & 仰臥位 $\rightarrow$ 立位 & $85 \%$ UM $40 \mathrm{cc}$ \\
\hline 14 & H. T & 26 & 우 & 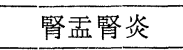 & 仰臥位－立位 & $\Delta 76 \%$ U G $20 \mathrm{cc}$ \\
\hline 15 & H. A & 21 & 우 & 腎孟腎炎 & 仰臥位 $\rightarrow$ 立位 & $85 \%$ U M $25 \mathrm{cc}$ \\
\hline 16 & H. K & 32 & 우 & 右水腎症 & 仰臥位 $\rightarrow$ 立位 & $85 \%$ UM $40 \mathrm{cc}$ \\
\hline 17 & M. $\mathrm{Y}$ & 34 & $\uparrow$ & 左水腎症 & 仰臥位 $\rightarrow$ 立位 & $85 \% \mathrm{UM} 40 \mathrm{cc}$ \\
\hline
\end{tabular}

$* \mathrm{UM}=$ Urokolin-M. $\quad \Delta \mathrm{UG}=$ Urografin.

事から, 腹膜後腔気体注入法を行つて及た. 即ち酸素 9 $00 \mathrm{cc}$ を腹膜後胿に注入して 3 時間後に撮影した。

前処置：施行せず.

所見： 第 9 困は腹膜後腔に酸素 $900 \mathrm{cc}$ 注入して撮 つた高圧間接撮影像であるが, 腸腰筋陰影虫明膫に描出 されている。注入された酸素は右腎の周囲に良く入つて

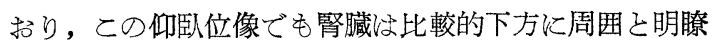
に区別されて描出されている。

iii）撮影成績： 腹部単純間接影法を高圧で行つてみ たが，第 3 表に示す如く腎輪郭が明膫に描出されたもの は腹膜後腔気体注入法学除いて 1 例も無く, 腸腰笳陰影
にもとれと同じ事が云えた. 又腸内容の固形物は消褪し て読影に支障を来さないものが多く, 腸内ガスはかなり 明瞭渵出されている. 腎部位に病的所見がある場合, 第11〜12肋骨は時に障害陰影となるが，乙れらは全例で 消褪し，読影に好都合である。腎結石について 3 例に体 位変換をさせて, 結石の立体構造を観察したが, 手術的 に除去した結石と大体似た所見をし線写真から得る事加 出来た. 腹膜後腔気体撮影法 1 例に本法を試みたが, 高 圧の利点を生かし，充分実用に供し得るものと思われ る. 又馬尾神経腫瘍による仙椎の変形を直接単純像で認 めたi例に本法を試みてみたが, 大体直接像に見る所見 
そ一致せる写真を得た．以上の成績から本法をもつて直 接単純撮影法に代える訳には行かないが, 高圧撮影の利 点を生かして, 気体腎㙉撮影法, 腹膜後腔気体撮影法及 び気体膀胱撮影法等に応用してみると充分臨床上役に立 つものこ思われる。

2）静注性腎孟間接撮影法

IVP 高圧間接撮影で試みてみた。正常例 4 例, 腎

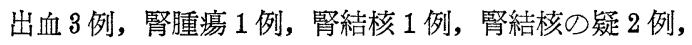
腰部腎変位 1 例, 腎孟腎炎 3 例及び水腎症 2 例, 計 17 例 に本法を試みた（第 4 表）.

i) 撮影方法

前処置： 被検者に下剂投与, 食事制限及び浣腸等は 全从行わず自由にさせ, 高濃度造影㓮静注によるアレル ギー性副作用, 例え沿嘔吐, 顔面潮紅, 熱感及び蘘麻疹 等の発現を予防する意味で多くの者に造影滆静注 30 分前 に抗ヒスタミン用の注射字行つた。

造影剂及び注入量： 造影剂は60\%ウロコリン $\mathrm{M}, 75$ \%ウロコリンM，76\%ウログラフイン及び85\%ウロコリ ンM等安使用してみたが，その使用量は60\%ウロコリン M 20cc成人に 1 例, 75\%ウロコリン M 30 40ccを成人に 2 例, $76 \%$ ウログラフイン $20 \mathrm{cc}$ を成人に 1 例及び $85 \%$ ウ ロコリンM25〜 40ccを成人 13 例に使用した。尚とれら使 用量洼体格により適宜増減した。

圧迫帯：圧迫帯は腎臟の自然の姿を観察する目的で 出来る限り使用しない方針で撮影を行つたが，2例のみ 使用した。

撮影体位，時間及び枚数：被検者をるず撮影台上に 背を向付て立たせ, 電動式による自動倒立裝置を動作さ せて撮影台を水平となし，目的とする部位にレ線管球を 合わせてから造影剤を上肢に静注する. 造影哃85\%ウ口 コリンM25〜40Ccを静注する場合，てれ活かなり高濃度 であるため注射開始より終了迄約 2 分〜 3 分の時間を要 した. 又アレルギー性副作用の予防上, 強いて急速に注 射を行うょうな事はしなかつた。撮影体位注仰卧位丈で 撮影したもの6 例, 最初から 6 枚目迄, 即与造影剂注入 後 9 分迄を仰卧位として, 以後腎臟の下垂, 上部尿路の 通過状態及び䐌孟の起立性反応による变化等を観察する 目的で撮影台を立位となし終り迄撮影したもの11例であ る. 又疾患によつては撮影台上で体位を種々変じて, 病 的陰影を立体的に分析した. 撮影時間及び枚数であるが 造影剤注射終了後すぐ仰臥位で 1 枚撮影し, 以後 1 分,

3 分, 5 分, 7 分, 9 分後と 2 分間隔で11枚撮影する が, 疾患によつてはこの時間を適宜変えて, 5 分間隔と
したり，排泄の遅れているような場合は10分間隔とし た. 一般に 2 分間隔で 20 分後迄撮影安行つたが, 最長は 40分後迄とした.

読影： 上記撮影方法によつて得られた $60 \times 60 \mathrm{~mm}$ 判連 続フイルムで腎孟, 珡杯の病的陰影の立体的観察, 左右 腎の運動及び排泄状態の比較, 腎下垂による腎盖, 腎杯 及び尿管の形態変化等を小型拡大レンズを有する Schaukasten で観察を行つた.

ii）代表的症例

症例番号 $3 . \mathrm{H}, \mathrm{S}, 51$ 才, 男子. 正常例

撮影目的：静注せる造影訪の腎杯, 㛑孟出現時間, 腎孟像が高圧間接撮影法でどのように描出されるか, 腎 杯, 腎孟及び尿管の形態観察を行つてみた。

前処置: 下郕投与, 食事制限及び浣腸等施行せず, 又抗ヒスタミン剬の注射も行わなかつた。

造影戍及び注入量： 85\%ウロコリンM40cc学静注し た. 注射終了迄約 3 分要した.

造影訪静注による副作用全くなし。

撮影体位，時間及び枚数：最初から終り迄圧迫帯な しで仰臥位のみで撮影した. 静注後 1 分, 3 分, 5 分を 2 分間隔で 17 分迄撮影し, 最後を 20 分として計 10 枚撮影 した.

造影剂の出現時間： 造影剂静注後 1 分では両側の腎 杯及び腎孟像の出現は認められず，3 分後で両側の腎 杯, 腎孟像が描出されている.しかし造影刻の充満が不 充分であるためとの 3 分後像で腎杯, 腎孟を読影する事 はやや困難である．とれが第10図の如く5分後になれば 左右共腎杯, 腎盂が良く描出されて来る. そして尿管陰 影も識別する事が出来る. これらの陰影は時間の経過に 従つて, 増々濃く造影されて強い陰影乞なつて描出され て7分後 (第11図) 〜 15分後で最高となり，漸次造影剂 が消失して行く、最後の 20 分後像（第12図）で、注左霄 孟, 下腎杯及び尿管に軽度造影訪峃残す程度となつたが, 右腎淌尚強く造影されている。左に比較して右腎の排泄 機能が少し劣つているものと思われる.

腎杯像：造影羭注射後 1 分では両側腎杯像以認めら れないが, 3 分で左右共, 上, 中及び下腎杯の出現を見 たが形態学的に良く分類出来る程度に造影されていな い. しかし 5 分後（第10図）に至れば左腎の上，下大腎 杯がはつきり現れ，右腎でも左腎よりや〉排泄は遅れて いるが腎杯, 腎孟が良く描出されている.7分後（第11 図)では一層, 筒杯及び腎孟像が鮮明に描出され, 左右 小腎杯, それの円蓋部も識別出来るようになつている。 
この 7 分後像で腎杯数安みてみると, 右では大腎杯 2 二 認められ，それぞれの大腎杯頂より小腎杯が上腎杯では

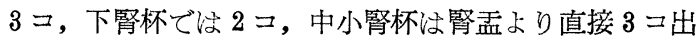
て抢り計 8 コの小腎杯像が観察される.左では大謷杯が 認めにくく尿管がそのま〉腎孟汇移行し, そこょり直接 小腎杯が出ている.小腎杯数梳上腎杯 3 コ, 下腎杯 3 二 の計 6 二の小腎杯からなつている. 尚腎杯の運動状態心 フイルム上から明瞭に観察する事が出来なかつた。

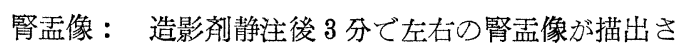
狆ている。しかし前にも述べた如く左は右に比べて幾分 排泄状態が良い。しかし 5 分〜 7 分後では左右共同程度 に充满され, 明膫な腎杯, 梷盂像が描出されている. 右

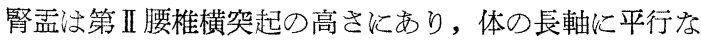

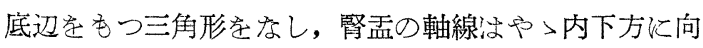
っている、そして緩やかなカーブを描いて漏斗状になり

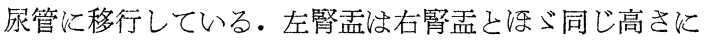
あつて，三角形をなさず，腎内腎孟及び腎外腎孟が同じ 巾で内下方に向い漸次細くなつて原管に移行している

(第11図).掔孟の収縮並に拡張が時間の経過を追つて連 続的に撮影したフイルム上で認められたが，IVPであ るため, 造影剤の充満が不完全で, 細部に渡つて観察す る事が出来なかつた。

尿管像：南側尿管像快静注後 3 分で現れておるが, 圧迫帯を用いていないので，常時造影剂が下方に向つて 流れて充分造影されていないが，5分後像（第10図）で はかなり鮮明に描出されている. 右側尿管は第II 腰椎下 縁より始まり第 III 第 V 腰椎横突起内側を下行し，骨盤 腔に入つて行く. 第 $\mathrm{I}$ 腰椎横突起先端に尿管の屈曲像が 認められ, この属曲像は数枚撮影しても不変であつて一 応病的変化己思われたが, そこょり上部尿路に桩張等の 病的変化が無く, 造影胴の排泄, 通過状態も良好で, こ れ丈では病的と云えないと思われる・左側尿管は右側と 同じ走行をとつて下行しているが, 右側の如き尿管屈曲 像は認められず，造影剂の消失，出現そして又消失々云 了所見から尿管の運動及び通過状態が観察され，第四〜 第 $\mathrm{V}$ 腰椎間に於いて尿管の左右弯曲, 即与腰部弯曲が尿 管の凸弯曲像から観察された。

症例番号 $10 . \mathrm{K} \cdot \mathrm{A}, 24$ 才, 女子.

主訴：左側腹部不快感

診断：左筒結核の疑

撮影目的：本症例は腎炎の診断で内科に入院してい た患者で, routine の腹部単純撮影, IVP で左腎下極に 一致して 10 円銅貨大の円形濃厚な石灰化陰影を認め, 既
往に左股関節結核があり，一念左腎結核病巣の石㕄化の 疑置いた例で，乙の石灰化像交立体的に観察する目的 で体位を变えて種々の角度から撮影してみた。

前処置：施行せず.

造影剂及び注入量：75\%ウロコリンM30ccを静注。 静注終了迄的 2 分要した. 又高濃度造影滆静注による副 作用は全く認められなかつた。

撮影体位, 時間及び枚数：造影剤静注後 3 分, 5 分 定仰臥位で，7分後左側下にして $30^{\circ}$ ，即与第血斜位 (第 3 図c), 10 分後 $60^{\circ}, 13$ 分後 $90^{\circ}$, 即与側位で撮影 L, 15 分後 $120^{\circ}$, 即与第II 斜位で, 20 分後 $150^{\circ}, 25$ 分後 $180^{\circ}$ 迴転 (腹臥位) させ， 30 分及び 35 分後の 2 枚 は元の仰卧位に戻して撮影した。撮影枚数は全部で10枚 撮影した。この症例は圧迫帯を使用した例であるが，20 分後の撮影迄しれを用い，それ以後はとりはずして撮影 した.

所見： 造影剂静注後 3 分で両側腎杯，腎孟像の出現 をみるが，5分後になればてれらの院影埂更に濃い院影 こなつて描出されて来る.腰椎をみてみると弯曲が認め られ，左腎下極に一致して比較的濃厚な円形陰影定認め る(第13図).この陰影は一様に濃い陰影として描出され ているが，一部淡い部分もあつて，一応結核病巣の石灰 化を思わせる所見である. そこで 7 分後, 撮影台上で左 側を下にして撮影台己患者の背面とのなす角を $30^{\circ}$ に傾 斜させて撮影する己第14図に示す如く，乙の円形院影は 正円形から棈円形と変り，左腎より遠く離れて外側に移 動している. 更に 10 分後 $60^{\circ}$ に体位を傾斜させると第 15図に示す如く左腎と円形陰影の間隔が更に大となり, 左腎と全く無関係である事が判明した．左腎孟は体位を 傾斜するにつれて漸次椎体に近づき，やがててれと重な

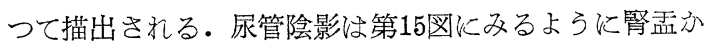
ら第II腰椎の高さで分れ, 椎体に沿つて第正腰椎上縁迄 下行してから椎体离離れて骨盤腔に入つて行く．左尿管 には狭窄及び㧓張等の病的陰影は認められない。更に体 位を変じて 13 分後 $90^{\circ}$ (側位)では，乙の陰影流第II 腰 椎上重なつているが椎体と区別出来た。そして25分後の $180^{\circ}$ (腹臥位)では第13図とは逆の位置に対称的に描 出されている. 以上の事よりとの円形㓌影は腎に近接す るものではなく，腎とはかなり離れた所のリンパ節の石 灰化像か或注壁に接近せる部位のリンパ節の石灰化像 がレ線の入射方向に対して左腎下極と前後して重なる位 置に存在したため, 仰卧位撮影像で第13図の如く病的陰 影と一見, 誤まつて読影したものである. 
症例番号12.S.Y, 24才, 男子.

主訴：右側腹部痛

診断：右側腰部腎変位.

撮影目的：本症例は上記を主訴として来院した者で あるが, routine のIVP で右側腰部腎変位の所見を呈 した. この側腹部痛が何に由来するものであるか不明で あつたが，結局腎蕉部の神経切除術によつて疼痛が軽減 した例である・とれを撮影した目的は，一般に腰部腎変 位络腎の迴転異常として腎孟が前方に向う廻転である事 が多く，とれを観察する意味で体位を变えて撮影した。

前処置：下郕投与，食事制限及び浣腸等は施行しな かつたが，撮影30分前に前処置こしてヒスタクール10mg を静注した。造影用静注による副作用は全くなかつた。

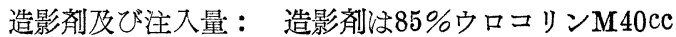
を静注した。注射終了迄約 2 分 30 秒要した。

撮影体位，時間及び枚数：体位々腎下垂の有無を見 るために最初㐫ら 6 枚目迄を仰卧位で，7枚目の11分以 後ね立位で撮影した。

そして腎蔵の迴転状態定観察する目的で，11分後は立 位で右側をフイルムに近づくように $30^{\circ}$ 傾斜, 即ち第IV 斜位となし，13分後注第IV斜位で撮影台と背面のなす角 $45^{\circ}$ ，15分後に今度々逆に左側定下にして撮影台乞背面 のなす角 $30^{\circ}$ (第政斜位),17分後及び 20 分後に元の立位 （正面位）に戻して撮影した。撮影時間及び枚数は造影 剂静注終了直後にまず 1 枚仰卧位で撮影し，次で 1 分 後, 3 分, 5 分己 2 分間隔で 9 分後迄仰臥位で撮影し, 7 枚目の 11 分後からは立位で体位を変じて 20 分後の11枚 で撮影を終つた。尚圧迫帯は使用しなかつた。

所見：乙の症例は両側共非常に腎機能が良く, 造影 剤静注直後の撮影で両腎の上，中及び下腎杯が殆んぞ同 特に造影凧の軽度出現をみるが，腎孟や尿管は造影され ていない。

1 分後の撮影では，両側の腎杯陰影が更に強く現れて いるが，未だ腎盂及び尿管像は出現していない。そして 3 分後に至れば第16図に示す如く，腎杯，腎典及び尿管 像が明膫に描出されている，右腎では腎孟と尿管が法ぶ 一直線上にあつて，乙の軸を中心にして腎盎の巾は広く なり，腎杯像も左右に向う定型的な腰部腎変位の像であ つて, 腎蔵の迴転異常のため腎孟は推体の外側に離れ， そこから尿管が内下方に向い，第 V 腰椎の高さで横突起 内側に入る. 即与体軸に対して尿管は約 $30^{\circ}$ の角で横突 起内側に入り，そのま 骨盤胿に下行している．とれに 反して左腎ではかっる変化が無く, 正常像を呈してい
る．時間を追つて連続的に撮影して行くと腎孟，尿管像 は一層明膫となり， 7 分〜 9 分後仰臥位撮影で最も鮮明 な像を得る事が出来た. 又左右尿管の運動も観察され た。との症例は右腎に呬転異常が在るのみで，その他腎 機能も全く正常で，造影剂の排泄も良好である。そこで 11分後，立位となして第 $\mathbb{V}$ 斜位をこらせ撮影台已被検者 との背面のなす角を $30^{\circ}$ として撮影を行つた所, 第17図 に示す如く腎の横径は短縮し，変位が一層強くなつてい るように描出されている．もしこれが仮に腎㙉が後方に 向うょうな廻転異常であるならば，か〉る体位で腎㙉像 は正常陰影に近づくはずであるが，迴転が一層強くなつ て来る事から，乙の迴転は㻉孟が前方に向う普通の腰部 腎変位である事が分る．さて造影刻はこの11分後像では 殆んご消失し，腎孟及び腎杯も狭く描出されているが， これは立位による腎盂及び腎杯の収縮, そして物理学的 な条件による造影珮の流出のためである．更に $45^{\circ}$ 傾け て撮影するとての迴転は一層強くなり，踃孟が前方に向 ろ事が分る。次に健側の左腎を下にして第而斜位，即与 撮影台と被検者の背面となす角を $30^{\circ}$ にして撮影する己 右腎はレ線管球に接近するため左腎よりや>拡大されて 現れているが，右腎の横径が延長し，正常腎孟像に近い 陰影を描出した．以上の事より本症の腰部珡变位は一般 に及られる腎孟が前方に向う迴転異常である事が本法で 確認された。との事は後に手術的にも証明された。

症例番号 $13.0 . \mathrm{H}, 22$ 才，男子.

主訴： 腰部不快感及び発熱

\section{診断：腎孟腎炎}

撮影目的：本症例坆腎監炎の診断で治療をうけて いた者であるが，第18図に見る如く，routine のIVP で右腎の腎孟尿管移行部の所に一見，㹨窄を思わせる陰 影があり，左腎では上腎杯茎部に狭小像及び腎孟が濃淡 二重に描出されている。これら病的陰影が機能的なもの で亦つて，器質的な变化ではないのかとの routine の 腎孟像丈では鑑別する事が出来ない，そとで本法を用い て連続的に撮影し, との狭小像を追求した。

前処置：下剂投与，食事制限及び浣腸等の前処置は 全く施行しなかつた．造影剂静注による副作用予防の目 的で撮影開始 30 分前にヒスタクール10mgの静注学行つ た。

造影剂及び注入量： 造影剂は $85 \%$ ウロコリン M $40 \mathrm{cc}$ を静注. 静注終了迄約 2 分 30 秒要した. 造影剂注射によ るアレルギー性副作用は全く見られなかつた。

撮影体位, 時間及び枚数：造影剂静注終了直後, 3 
分, 5 分, 7 分及び 9 分後の 5 枚を仰臥位で撮影し，腎 下垂, 腎臓の起立性反応等を観察するために11分, 13 分, 15 分, 17 分及び 20 分後证立位で撮影した. 計10枚撮 影したが，圧迫帯は使用しなかつた。

所見：第19図は造影剂を注射した直後に撮影したフ イルムであるが, 未だ両腎の腎杯, 腎孟は出現していな いが，両腎の腎実質像が描出されている．とのネフログ ラム左腎の方が良く現れている. 又とのフイルムでは 腸腰筋陰影等も比輍的良く描出されている. 3 分後の撮 影では両側腎杯, 腎典像が鮮明に現れていて, 腎杯像は 上，中及び下腎杯が同時に出現している．2分間隔で連 続的に撮影したので, これら腎杯, 腎孟像は抬そらく 1 分 30 秒 2 分 30 秒の間に現れているものと思われる. С の 3 分後像から見ても両腎の機能相当良いものと考元 られる。尿管陰影はこの3 分後像では認められず， 5 分 後像で明膫に現れている(第20図).この5 分後像に見る 如く, 耐腎の腎杯, 督孟及び尿管陰影が良く描出されて いるが，第18図にみる如き右腎の腎孟尿管移行部の所に 狭小像は認められない。しかし左腎の上腎杯荎部の狭小

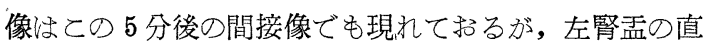
接像に見る如き二重陰影はこの5 分後像であまりはつき りしない。

又直接低圧像で左上警杯が第12肋骨先端乞重なつてい るが (第18図), 高圧間接像 5 分後のフイルム(第20図) ではこの陰影が消煺していて, 腎杯の読影に好都合であ り, 更に高圧では下郕投与, 食事制限及び浣晹等つ前処 置を行つていないにも拘らず, 腸内容が消裉してフイル ムを読影するのに好都合である. 次に7 分後のフイルム を見てみると，第21図に見る如く，一見狭窄を思わせる 所見が右腎孟尿管移行部に認められ，乙れは第18図の直 接低圧像の所見とや〉一致するが，下部尿管が鮮明に描 出されて抢り，尿管の通週障害は無いものと思われる. 一方左腎の上腎杯蕉部の狭小像はこの 7 分後のフイルム では消失し，連なつていて又腎孟の二重陰影も認められ

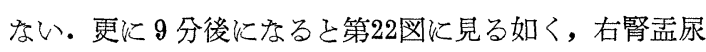
管移行部の狭小像消失し，尿管が腰部弯曲を示して下 部尿管迄良く現れている・左腎では上腎杯茎部の所見は 7 分後像とあまり変らないが, 腎盎はや>収縮してい る. 左尿管には特に病觛変化は認められない. 以上の所 見から routine のIVP (第18図)でみられた左右の変 化は器質的なものでなく機能的なものであり, これら右 尿管, 左腎杯及び腎孟の収縮時に撮影されたため一見病 的陰影のように現れたものと思われた. しかし, 両腎に
腎孟の軽度拡張像が在るため, 腎下垂の有無, 腎蔵の起 立性反応をみるため, 6 枚目の11分後に立位となし，撮 影を行つたが造影剂は殆んご消失していて腎孟，腎杯像 の形態観察は不可能であつた。即ち立位による腎臓の起 立性反応のため造影威の急激な流出が起りとのような所 見を呈したものと考える.との11分後立位像（第23図） で両側腎の軽度下垂が僅かに残る造影剂でみる事が出来 るが, とのょうに立位で腎杯, 腎盎像が消失する事から 両腎の機能は組当良いもの己思われる.13分以後の>ィ ルムで洔別な所見は得られなかつた。

iii）撮影成績：下郕投与, 食事制限及び浣腸等の前 処置を全例に行わなかつた・読影飞支障を来したものは 1例も無かつたが，腸内ガスはかなり著明に描出されて いるので 2〜 3 の例で読影上不都合を生じた. 17例中 6 例に撮影前何ら抗ヒスタミン削の注射を行わなかつた が，亏ち4例にアレルギー性副作用全くなく，2例に軽 心嘔気, 咳, 顔面潮紅及び蘘麻疹等がみられ, 抗ヒス夕 ミン剂の注射定行つた残り11例中 5 例には副作用全くな く，6例に同じような副作用をみた。しかし，とれらの 副作用は $4 \sim 5$ 分で消失し, 殆んぞ問題にならなかつ た. 圧迫帯の使用は 2 例にの及行い, 他の15例では無圧 泊で撮影したが, 得られた像にはしれの使用有無による 大きな差違は認められなかつた。造影郕は 1 例に60\%ウ ロコリンMを20cc用いて撮影したが, 造影が惡く読影す る事が出来なかつた．次に $76 \%$ ウログラフインを $20 \mathrm{cc}$ 用 いて及たが, やはり充分な腎盘像が得られず細部に渡つ て検討する事が出来なかつた.そとで75\%ウロコリン $\mathrm{M}$ を30〜40ccを 2 例に静注して撮影を行つた所, かなり鮮 明な腎孟像が得られた。しかし, 85\%ウロコリン Mの試 供学得て更に明膫な腎孟像の描出が可能となり, 残り 13 例に85\%ウロコリンM25４0cc学用いて全例に満足せる 腎㙉像の描出に成功した。とれら得られたフイルムはか なり鮮明で充分実用に供し得るものと思われる。

正常と思われる右 6 腎, 左 6 腎の計12腎について腎 杯, 腎盂及び尿管像の出現時間を見てみると第 5 表に示 す如く，仰卧位で造影剂注入後 1 分ですでに腎杯像の 現れているもの 4 腎あるが, しかし造影滆の充満は不 充分である.腎杯像の出現時間は平均 2 分〜 3 分であつ た. 腎盎ではこれょり少し遅れて, 最も早く腎㙉像の得 られたものは 2 分 30 秒であつたが, 大体 3 分で出現して いる. 尿管は更に遅れ, 早いもので 3 分後, 大体 3 分 5 分であつた.これら腎杯, 腎盂像怔大体 3 分後で読影 する事が出来るが，5分後になると，乙れらの陰影は一 
第 5 表 正常 12 腎の静注性腎血間接撮影成績

\begin{tabular}{|c|c|c|c|c|c|c|c|c|c|c|c|c|}
\hline \multirow{2}{*}{$\begin{array}{l}\text { 右 } \\
\text { 督 } \\
(6)\end{array}$} & \multirow{2}{*}{ 名 } & \multirow{2}{*}{ 年 } & \multirow{2}{*}{ 性 } & \multirow{2}{*}{\multicolumn{2}{|c|}{ 造影剤注入量 }} & \multirow{2}{*}{ 撮影体位 } & \multicolumn{3}{|c|}{ 造影剤出現時間 } & \multirow{2}{*}{$\mid \begin{array}{l}\text { 鮮明なピ } \\
\text { エログラ } \\
\Delta\end{array}$} & \multicolumn{2}{|c|}{ 腎 杯 数 } \\
\hline & & & & & & & \multicolumn{3}{|c|}{ 腎 杯腎 } & & \multicolumn{2}{|c|}{ 大腎杯小腎杯 } \\
\hline 1 & A. $\mathrm{K}$ & 52 & 우 & $75 \% \mathrm{UM}^{*}$ & $40 \mathrm{cc}$ & 仰臥位 & $2^{\prime} 30^{\prime \prime}$ & $2^{\prime} 30^{\prime \prime}$ & $4^{\prime}$ & $5^{\prime} \sim 8^{\prime}$ & 2 & 7 \\
\hline 2 & H. M & 23 & $\hat{\delta}$ & $85 \% \mathrm{UM}$ & $40 \mathrm{cc}$ & 仰臥位 & $2^{\prime}$ & $2^{\prime} 30^{\prime \prime}$ & $3^{\prime}$ & $5^{\prime} \sim 10^{\prime}$ & 3 & 8 \\
\hline 3 & M. $\mathrm{M}$ & 21 & $\hat{o}$ & $85 \% \mathrm{UM}$ & $40 \mathrm{cc}$ & 仰臥位＜wide>－立位 & $1^{\prime}$ & $3^{\prime}$ & $3^{\prime}$ & $5^{\prime} \sim 9^{\prime}$ & 2 & 6 \\
\hline 4 & I. $\mathrm{M}$ & 44 & $\hat{o}$ & $85 \% \mathrm{UM}$ & $40 \mathrm{cc}$ & 仰臥位＜wide>－立位 & $3^{\prime}$ & $3^{\prime}$ & $5^{\prime}$ & $5^{\prime} \sim 9^{\prime}$ & 2 & 6 \\
\hline 5 & U. $\mathrm{Y}$ & 31 & $\hat{0}$ & $85 \% \mathrm{UM}$ & $40 \mathrm{cc}$ & 仰臥位＜wide>＜wide>立位 & $1^{\prime}$ & $3^{\prime}$ & $3^{\prime}$ & $5^{\prime} \sim 9^{\prime}$ & 0 & 8 \\
\hline 6 & H. S & 51 & $\hat{0}$ & $85 \% \mathrm{UM}$ & $40 \mathrm{cc}$ & 仰臥位 & $3^{\prime}$ & $3^{\prime}$ & $5^{\prime}$ & $9^{\prime} \sim 13^{\prime}$ & 2 & 8 \\
\hline \multirow{2}{*}{$\begin{array}{l}\text { 左 } \\
\text { 腎 } \\
(6)\end{array}$} & \multirow{2}{*}{ 名 } & \multirow{2}{*}{ 年 } & \multirow{2}{*}{ 性 } & \multirow{2}{*}{\multicolumn{2}{|c|}{ 造影剤注入量 }} & \multirow{2}{*}{ 撮影体位 } & \multicolumn{3}{|c|}{ 造影剤出現時間 } & 鮮明なピ & \multicolumn{2}{|c|}{ 腎 杯 数 } \\
\hline & & & & & & & 腎 杯 & 腎 孟 & 尿 & $\mid \begin{array}{l}\Delta \\
\Delta\end{array}$ & 大腎杯 & 小腎杯 \\
\hline 1 & A. $\mathrm{K}$ & 52 & 우 & $85 \% \mathrm{UM}$ & $40 \mathrm{cc}$ & 仰臥位－立位 & $1^{\prime}$ & $3^{\prime}$ & $7^{\prime}$ & $5^{\prime} \sim 9^{\prime}$ & 0 & 6 \\
\hline 2 & S. $K$ & 61 & $\hat{\delta}$ & $75 \% \mathrm{UM}$ & $40 \mathrm{cc}$ & 仰臥位 & $2^{\prime}$ & $3^{\prime}$ & $5^{\prime}$ & $5^{\prime} \sim 8^{\prime}$ & 2 & 6 \\
\hline 3 & M. M & 21 & $\hat{0}$ & $85 \% \mathrm{UM}$ & $40 \mathrm{cc}$ & 仰臥位＜wide>＜wide>立位 & $3^{\prime}$ & $3^{\prime}$ & $5^{\prime}$ & $5^{\prime} \sim 9^{\prime}$ & 2 & 6 \\
\hline 4 & I. M & 44 & $\hat{0}$ & $85 \% \mathrm{UM}$ & $40 \mathrm{cc}$ & 仰臥位＜wide>＜wide>立位 & $1^{\prime}$ & $3^{\prime}$ & $3^{\prime}$ & $5^{\prime} \sim 9^{\prime}$ & 2 & 5 \\
\hline 5 & S. Y & 24 & $\hat{0}$ & $85 \% \mathrm{UM}$ & $40 \mathrm{cc}$ & $\begin{array}{c}\text { 仰臥位 } \\
\end{array}$ & $3^{\prime}$ & $3^{\prime}$ & $5^{\prime}$ & $9^{\prime} \sim 13^{\prime}$ & 0 & 6 \\
\hline 6 & H. S & 51 & $\hat{0}$ & $85 \% \mathrm{UM}$ & $30 \mathrm{cc}$ & 仰臥位 & $5^{\prime}$ & $5^{\prime}$ & $7^{\prime}$ & $9^{\prime} \sim 13^{\prime}$ & 2 & 9 \\
\hline
\end{tabular}

層鮮明に描出されて来るので細部に渡つて検討する事が 出来る。

尿管像についてもこ机々同じ事が云え， 3 分後で尿管 像が現れているが，無圧迫のため造影剤が常に下部尿路 へ流れて造影が惡く, 腎盎内に造影剂が多く集る5 分後 で鮮明に現れている.そしててれら腎杯, 腎盂及び尿管 像流 9 分 13 分で最高に達し, 15 分以後は漸次陰影が薄 れて行く事が観察された。しかし, 仰臥位で 9 分後迄 2 分間隔で撮影し，11分後から立位にすると正常腎では起 立する事により腎臓に起立性反応が起り腎盂は強く収縮 して腎孟内に存在せる造影剂を腎孟外渄泄するため, 腎杯及び腎冏像が殆んご消失して読影出来なくなつてし まう.しかし, 最後の 20 分後の撮影でも腎杯に僅かなが ら造影剤を認めた。正常12腎の腎杯数, 腎孟の形態等を 見てみると第 5 表の如く, 右腎では大腎杯 2 コのもの 4 腎, 3 コのもの 1 腎及び大腎杯の認められないもの 1 腎 で, 左腎では 2 コのも 4 腎, 大腎杯の認められないも の 2 腎であつたが，左右腎共大腎杯数が 2 コのものが多 く，3コのものは少いが，大腎杯が認められず，尿管が そのま>腎㙉に移行し, 腎孟から直接小腎杯の出ている 型，所謂 I 型bに相当するものが 3 㛑認められた. 小腎 杯数は右霄で 8 コのもの 3 腎, 6 コ 2 腎及び 7 コ 1 腎で あり, 左腎では $6 コ 4$ 腎， $5 コ 1$ 腎及び 9 コ 1 腎であつ た.
腎出血の 3 例では 1 例に60\%ウロコリンM $20 \mathrm{cc}$ 静注し たが充分な腎㙉像が得られなかつた。他の 2 例では特別 な所見を得る事が出来なかつた。腎腫瘍の 1 例では本撮 影法により直接低圧像に劣らぬ腎杯及び腎孟の陰影欠損 や腎杯茎の延長等の腎腫瘍飞特有な所見が得られた。 鈁結核の 1 例では routine のIVPで尿管の描出が無 く, 本撮影法の 30 分後像でてれを描出し得た. 又空洞も 読影出来, 上部尿路に通過障害の無い事をむ確認した. この症例等は延引性静注性腎盖撮影法の必要性を物語つ ている.腎結核の疑 2 例のうち 1 例が症例番号10で述べ たものであつて, 撮影体位を変える事によつて左腎下極 の円形陰影が腎々は無関係である事が分り，他の1例も 体位を変じて腎杯の重なりによる病的陰影を分析し，こ れが正常である事を証明し，造影永の腎杯，腎孟出現時 間及び排泄状態もかなり良く異常でない事が分つた症例 である・

腰部腎変位の 1 例は症例番号 12 亿示す如く, レ線の被 写体に対する投射角を種々変えて撮影する事により腎蔵 の迴転が腎孟の前方に向う縱軸迴転であつて, 普通に見 られる型の腰部腎変位である事が分つた．腎孟腎炎の 3 例中 1 例に $76 \%$ ウログラフイン $20 \mathrm{cc}$ 静注して撮影を行つ たが腎盂像は不鮮明で読影困難であつた.しかし他の 2 例では $85 \%$ ウロコリンM40cc静注する事により鮮明な雫 盐像が得られた. この 2 例中 1 例は症例番号 $13 て ゙$ 述べた 
もので連続的撮影を行つて, 腎杯, 腎孟及び尿管の狭小 像が機能的変化である事が分つた症例で，他の 1 例は何 ら特別な所見示さなかつた. 水腎症の 2 例中 1 例は左 腎孟に強い搪張像が現れている例で, routine のIVP の15分後像で尿管の狭窄部位がはつきりしなかつたもの で本法の30分後像でてれを描出し得た. そしてての症例 では腎臓の起立性反応が消失していて, Hutter 氏症状 が認められた。即ち仰臥位撮影で左腎㙉の著明な拡張像 があり, 左腰筋に接していて立位による撮影でもこの拡 張せる腎孟像は消失する事が無く, そのま〉の状態を残 す事から左輎の機能性かなり低下している事が分る。こ れに反して右腎では殆んぞ腎孟像が消失している。との 症例の仰卧位 15 分後像（第 24 図）及び立位 30 分後像（第 25図）をると以上の事が充分理解出来るものと思われ る.他の水腎症の 1 例で恃特別な所見を認める事が出来 なかつた. 以上本法による撮影成績を簡単に述べて来た が, 高圧間接撮影を IVP に応用しても充分実用に供し 得る腎孟像を描出したが, 本法をもつて従来のIVPに 代える訳に注行かないが, routine のフイルムで病的陰 影を認脄場合，乙れを更に詳細に検討するのに非常に 役立つものと考えられる.

3）逆行性腎盂間接撮影法

RP を高圧間接撮影法で試及て及た。腎出血16例（左 11例, 右 5 例),靔下垂症 10 例 (右 6 例, 両側 4 例), 水腎 症 4 例（左 1 例, 右 1 例及び両側 2 例) 及び其の他 6 例 （督結核の疑 2 例, 督結核 1 例及び尿路結石 3 例) の計 36列飞本法を試及た。とれらのうちから代表的症例を示 し，正常已思われる右腎 8 ，左腎 7 の計15腎について腎 杯, 腎盂, 尿管の形態や運動及び腎杯, 筲孟内に注入さ れた造影剤の排泄時間等に就いて検討を加え, 更に婜出 血及び腎下垂症における所見を述べる.

i) 撮影力法

前処置： 全例に食事制限，下剂投与及び浣腸等の前 処置を施行しないでそのま〉撮影した.

造影剤及び注入量： 造影滆は60\%ウロコリンMを 32 例に，75\%ウロコリンM字 4 例に使用した。注入量は左 右腎共に最少量 $2.5 \mathrm{cc}$, 最大量 $20 \mathrm{cc} て ゙$ 平均 $10 \mathrm{cc}$ 注入し た、尿管カテーーテルをあらかじめ㨂入して执いた被検者 を最影台上汇仰卧位をとらせてから次に透視を行い, 目的とする部位䎲レ線管球を合わせて, 造影剤学極めて

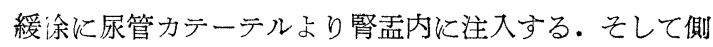
腹部に緊張, 圧迫感が出現する直前で注入を中止するよ うにした。しかし routine の腎孟レ線像で，腎杯及び
腎孟に拡張が見られたものでは注入する造影用の量を適 宜増量した. 又注入量が少量でも側腹部に緊張, 圧迫感 等が現れた場合は注入を中止した。

撮影体位, 時間及び枚数：撮影体位は全て仰卧位の もの 5 例, 立位丈のもの6 例, 最初の 1 枚安仰卧位で撮 影し 2 枚目より立位をなして行つたもの 25 例で, 又必要 に応じて体位を撮影台上で斜位となしレ線の被写体に対 する投射角を種々変えて撮影してみた。撮影体位を全て 仰㗅位又は立位で行う場合には両側尿管カテーテルょり 造影郕を注入し, 注入終了直後に 1 枚撮影し, 次に尿管 カテーテルを拔去して 30 秒間隔で 5 分迄11枚撮影して最 後は 8 分後に撮つて計12枚の撮影である.

しかし routine のレ線腎㙉像で腎杯, 腎㙉に拡張像 が見られる例ではこの撮影間隔を適宜延長した。 又仰卧

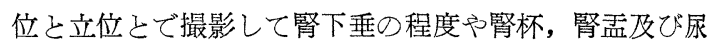
管陰影の变化等を観察した症例では, 初め仰臥位で造影 鼡を注入終了直後に 1 枚撮影し, 造影郕の流出を防ぐ目 的で尿管カテーテルは抜去しないで括き，撮影台の電動 倒立裝置でこれを立位となし, 1 分後に撮影台が立位と なつた所で尿管カテーテルを拔去して 2 枚目の撮影を行 い, 以後 30 秒間隔で 5 分後迄 10 枚撮影し, 更に 6 分後及 び 8 分後さ計 12 枚撮影した.

読影：以上述べて来た撮影方法によつて得られた 60 $\times 60 \mathrm{~mm}$ 長尺判の連続フイルムを腹部単純間接撮影法や静 注性腎盂間接撮法の時と同じょうに直接低圧像と比輘し ながら小型 Schaukasten で観察する。

ii）代表的症例

症例 1. N.H, 63 才, 男子. 正常例

撮影目的：逆行性に充満された正常腎の腎杯, 腎孟 の形態, 運動並びに腎孟腎杯への逆流現象, 腎杯や腎孟 内に注入された造影敃の排泄時間等を観察する目的と $\mathrm{RP}$ が高圧間接撮影法では如何なる影像を呈するか等 をみるために本撮影法を試みてみた。

前処置：施行せず.

造影剤及び注入量： $60 \%$ ウロコリン $\mathrm{M}$ 両側10 ccづ つ極めて緩徐に注入.

撮影体位，時間及び枚数：仰臥位で造影剤注入終了 直後 1 枚撮影し, 次で撮影台を立位にしてから尿管カテ 一テルを拔去し 2 枚目の撮影を行い, 以後 30 秒間隔で 5 分後迄10枚撮影し, 8 分後にもう1枚撮つて計11枚撮影 した.

腎杯像：右腎で汸第26図で見る如く，大腎杯が上下

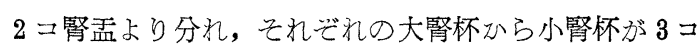


づつ分岐している. 造影滆の注入量が少し 過量のため 亦, 腎杯の辺縁がや>円形を呈し, 小腎杯が膨らんでい る. 左腎ではやはり大腎杯が 2 つ観察され, 各々の大腎 杯より小腎杯が 4 コ，5コ分岐していて左右腎注ざ対 称的である. 左腎に於いても右腎同様, 造影成の過剩注 入による腎杯像辺縁のぼけ，腎杯の膨らみが見られた。 造影剤注入 1 分 30 秒後立位になると, 左右上腎杯像は消 失して形態を読影する事が出来ないが，中及び下䐌杯に はあまり大きな変化認められない.しかし 2 分 30 秒後 に至る己第27図泟示如く右腎では上腎杯系の消失, 中 腎杯の一部消失がみられ，左腎では上，中腎杯及び腎孟 の消失がみられ，更に下腎杯系も消失しかけている。乙 れが 3 分 30 秒後になれば，左腎の腎杯系及び腎孟像は殆

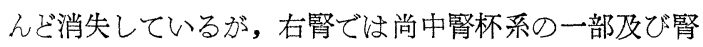
孟像が㜔影出来る.しかし 4 分後ではこれらの陰影も殆 んぞ消失してしまう。尚腎杯系の運動は30秒間隔の撮影 で々詳細に渡つて観察する事が出来なかつた。

腎孟像：右腎孟は第 III腰椎上縁の高さにあつて体軸 に平行な底面を持つ三角形に近い漏斗状をなして，ゆる や办なカーブを描いて内下方に向い尿管に移行してい

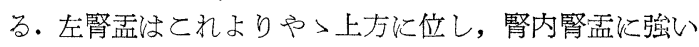
収缩がみられる。腎外腎盘は体軸と約 $30^{\circ}$ の角定なして 内下方に向い第 III 第IV腰椎間で尿管に移行している. 造影剂注入 2 分 30 秒後では左腎盂の消失を見るが（第 27 四)，右腎では最初に撮影した腎孟像の約 $1 / 2$ の巾で尚も造 影されているが，3 分 30 秒後に至ると第 28 図の如く右腎 寻つ陰影慬かに認められる程度になつている。

泒管像：右尿管以腎孟尿管移行部でくの字型に屈曲 しているが（第26図)，1分後立位撮影では，乙の屈曲が 消失し, 1 分 30 秒で再度屈曲陰影が出現しているが 2 分 30 秒後で又消失している (第27図). 即ち尿管の腰部咢曲 功観察される．左尿管に於いてもこの運動が見られた。

艄杯及び腎孟内造影剤の消失時間：逆行性に腎杯，

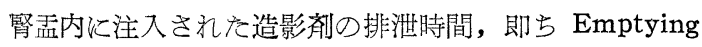
time 左右霄で各腎杯別及び腎孟でみてみると, 左右 謷共に上腎杯が最も早く, 注入後 1 分 30 秒で上腎杯像の 消失を及, これよりや>遅れて中腎杯が左 2 分 30 秒後 比, 右 3 分 30 秒後に消失し, 最後に下腎杯の消失となつ ている. 右腎では 3 分 30 秒後尚下腎杯像が認められ（第 28図),左腎ではすでに消失しているが一部造影用が残つ ている所があるが 4 分後ではこれらの陰影は全て消失し ている.腎盎排泄時間は右腎瑥で腎杯より更に遅れて4
分後，左腎孟では 2 分 30 秒後に造影剂の消失を認めた。 以上の事から右と比較して左の方が若干早い上うに思わ れる.尚腎孟腎杯への逆流現象核認められなかつた。 症例 2.S.H, 29才, 女子.

主訴：右側腹部不快感及び発熱

診断：右腎結核の疑

撮影目的：この症例は時折現れる右側腹部の不快感 及び発熱を主訴として某医の下で腎盂腎炎の診断を受け て加療していたものであるが, routine のレ線腎孟像に 一見空洞を思わせる病的陰影が右中腎杯部位に一致して 描出され，腎結核の疑でこの陰影を観察する目的で本法 を試みてみた。

前処置：施行せず.

造影剂及び注入量： $60 \%$ ウロコリンMを両側尿管カ

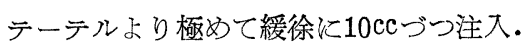

撮影体位，時間及び枚数：撮影体位は全て仰臥位 で，体位を一部傾斜させて撮影を行つた。即与患者を撮 影台上に仰臥位となし, 造影訪注入直後 1 枚撮影し, 尿管カテーテルを拔去して 30 秒後 2 枚目を撮影した. 次 に 1 分後撮影台上で右側を下にして撮影台と患者の背面 となす角を $30^{\circ}, 4$ 分後 $60^{\circ}, 6$ 分後 $90^{\circ}, 7$ 分後 $120^{\circ}$, 8 分後 $150^{\circ}$ 及び 10 分後 $180^{\circ}$ (腹臥位)にして計 8 枚撮 影した.

所見： 第29罒に見る如く右腎盂々認め難く，尿管が そのま〉大腎杯に移行しているような感を呈し, そして 右中腎杯に不正形の一見空洞と思われる病的陰影があつ て，このレ線写真 1 枚丈ではこれが空洞であるが゙うか 鑑別する事が出来ない. そとで1 分後右側を下にして撮 影台と患者の背面となす角を $30^{\circ}$ にして撮影を行つて及 た所, 第30図に示す如くとの院影は認められず，実は中 腎杯が互にレ線投射方向に対して仰卧位で重なり合う位 置にあつたために生じた陰影である事が分つた。 4 分後 更に $60^{\circ}$ に傾斜させて撮影してみるとての事が一層明ら かであり腎杯像が両側に分れて腰部腎変位の場合にみる レ線像と似を型をとつている.そしててれらの腎杯像山 腰椎と一部重なつているが, 高圧撮影のため骨陰影が消 裉して読影に支障を来さなかつた（第31罒）。腎杯及び腎 盖の所謂 Emptying time は, 右腎で 8 分後腎杯及び腎 孟像の消失を見，左腎では 4 分後消失を見た。腎盐腎 杯への逆流現象はこの症例で比較的良く観察された。第 29,30 及び31図に見る如く，右覑の下腎杯にこの現象が 及られ, 一度造影された右下腎杯像が消失し, 再度造影 されている状態を第32図に示した。 
症例 3 ．K.R，41才，女子.

主訴：肉眼的血尿

診断：左腎出血

撮影目的：乙の症例は肉眼的血尿を主訴として来院 し, 膀胱鏡検查で左腎出血を認めたもので, 腎杯, 腎盎 の形態や尿管の運動, 更に腎杯, 腎孟の Emptying time 等を観察する目的で本法を試みた。

前処置：施行せず。

造影剂及び注入量： $60 \%$ ウロコリンM学両側尿管カ テーテルょり10ccづつ極めて緩徐に注入.

撮影体位，時間及び枚数：患者を撮影台上に仰卧位 となし, 造影滆堂注入終了直後 1 枚撮影して, 次で撮影 台字立位已なし尿管カテーテルを拔去して 2 枚目の 1 分 後像を撮影した. 以後 30 秒間隔で 5 分後迄 10 枚連続的に 撮影し, 6 分後及び 8 分後の計 12 枚撮影した.

所見：第33図は仰臥位で造影剤注入終了直後の腎孟 像であるが，左右の腎盖像を比較してみると左腎が右腎 よりもかなり大きく腎杯像の辺縁も尖鋭でない。右腎孟 注第II 腰椎下縁にあつて, 腎孟より上下 2 コの大腎杯が 分れ，その大腎杯よりそれぞれ 4 二及び 3 コの小腎杯が 分岐している。これらの腎杯像の辺縁は尖鋭であつて形 態学的に何ら異常所見以認められない. 左腎㙉汸右に比 較してかなり大きく, 第 I 〜 II 腰椎間の高さに在つて, 腎盂より 2 コの大腎杯が上下に分れ，とれょり 2 コづつ 小腎杯が分岐している，そしててれ等の小腎杯法第33図 にみる如く辺縁が尖鋭で無く，軽度拡張が見られ，下腎 杯に一見病的と思われる腎杯の変形像が認められる. 又 左尿管にも掋張像がみられる。そこで撮影台を立位とな して撮影を行つた。第 34 図は造影剤注入後 1 分, 立位の 腎孟像であるが, 右腎孟は 1 腰椎の高さだけ下垂し, 上 腎杯像治殆んで消失し腎孟像が薄く描出されていて造影 凨の排泄が良好である事を示す。これに反して左腎では やはり立位により1腰椎の高さだけ下垂しているが，造 影剤の排泄が惡く, 1 分後の立位像で上腎杯陰影が一部 消失している程度であつて腎孟像は尚明膫に描出されて いる. 1 分 30 秒後では右腎の、腎杯系は完全に消失 し, 腎孟像が僅かに認められる程度となり，左腎では上 腎杯系の消失を見るのみで，中，下腎杯系及び腎孟像は 依然として明瞭渵出されている．2 分後になるとてれ 等左腎の腎杯，腎盎像もその殆んごが消失して，時間の 経過につれて消失したてれ等の陰影は 2 分後吕ら 4 分後 迄では最初に見られたような造影剤の急激な消失は認め られないが，4分後で左右腎杯，腎孟像の完全消失を見
たが，左腎では，造影郕が 1 力所点状に残る部位が認め られ，乙の陰影は 8 分後の最後の撮影（第35図）に至る 全てのフイルムに認められ，尚本態は不明なるがかつる 興味ある所見を得た。第36図は本症例の腹部単純像であ る.以上の所見からも分る如く, 上部尿路に通過障害が 無く, 両腎の Emptying time も正常範囲内であつた が，本症例で左掻孟が大きく，下腎杯に一見病的陰影己 思われる腎杯の変形並びに造影哃が点状に 1 力所残る所 があり，とれらの所見がいずれも左側である事と左腎出 血とが何か関係があるのではなかろろか。

症例 $4.0 . U, 26$ 才，男子。

主訴：両側腹部鈍痛及び腰痛

診断：両側水筱症

撮影目的：本症例恀両側腹部の鈍痛及び腰痛を主訴 こして来院した者であるが，既往に約 2 力月前，右尿管 結石の手術を受けている. routine のレ線腎㙉像で両側 水腎症の所見を呈した。そこでこれの腎杯，腎孟及び尿 管の形態，腎杯，腎孟の排泄時間，腎の下垂状態及び水 腎症の原因追求の目的で本法を試みた。

前処置：施行せず

造影剂及び注入量： $60 \%$ ウロコリンM定両側10 ccづ つ注入.

撮影体位，時間及び枚数：最初仰臥位で造影剂注入 終了直後に 1 枚撮影し, 次に撮影台を立位にしてから尿 管カテーテルを拔去して，2枚目の1分後像の撮影を行 つた. 以後 30 秒間隔で 5 分後迄 10 枚撮影し， 6 分及び 8 分後己計12枚撮影した。

所見：第37区は仰臥位で造影剤を両側腎孟内に注入 終了直後に撮影した腎孟像であるが，両側腎孟の高さは ほぶ同じであつて右が幾分低い。両側腎盖には掘張が みられるが，乙れに比べて腎杯系に站拡張があるり無 い。そこで撮影台を立位となし連続的に撮影を行つた。 第38図は造影剂注入後 1 分の立位像であるが，耐腎共に 殆んご下垂は認められず，すでに両側上腎杯像の消失を みる.そして右が左に比し幾分造影滆の排泄が良く, 両 腎共に Narath 氏症状が認められ腎盂の緊張低下が予想 される，造影剂注入終了直後に仰臥位で撮影した腎孟稘 (第37図)では, 形態学的に左右差が認められないが, 1 分後立位像では第38四の如く左腎では腎外腎孟にも搪 張像が現れ，造影訪の排泄状態も惡く，左右差がこの立 位像で著明に現れている. 又左尿管には第IV腰椎の高さ で屈曲像が認められ，第37図及び第38図でもとの屈曲は 変り無 $く, 3$ 分 30 秒後の撮影でもやはり同じょうに屈曲 
陰影がみられた（第39図）.との事より尿管のか〉る変化 は機能的なものでは無く, 何か器質的な变化が疑われ る.腎杯及び腎孟の所謂 Emptying time は両側上腎杯 は立位 1 分後で，腎杯像の消失を 久(第 38 図), 1 分 30 秒 で右中腎杯の消失をみるが左では尚造影されている。造 影凮注入後 2 分では右腎盂像の完全消失, 下腎杯像字か すか認める程度さなつているが，左腎では腎㙉及び下 腎杯共飞尚かなり強く造影されている．2 分 30 秒では左 中腎杯像の消失をみ, 右では尿管陰影の消失をみた。 3 分ではまり大きな変化が無 $<, 3$ 分 30 秒で第 39 図に見 る如く右下腎杯像が右では認められる程度であるが，左 では中，下腎杯及び腎孟像が尚はつきりと描出されてい
る，時間が経過するに従つて，てれら左腎の腎杯，腎孟 像も漸次消祀して行くが，8 分後の最後の撮影(第40区) に於いても完全に消失しなかつた，以上の如く左䇾孟の 拡張の原因は尿管の器質的変化による屈曲のために起つ たものと考元られ，右腎孟の拡張の原因は本法で明らか にする事が出来なかつた。

iii）撮影成績：高圧間接撮影法 RP 36例飞試及 全例に鮮明な腎杯，腎孟像の描出に成功した。得られた 像は決して routine のレ線腎孟像に劣るものではなく 充分実用に供し得るものと思われる。下剤投与，食事制 限及び浣腸等の前処置を全例に行わずに撮影したが，高 圧撮影のため腸内容は消褪して読影に支障は来さなかつ

第 6 表 正常 15 腎の逆行性腎間接撮影成績（右 8 腎, 左 7 腎)

\begin{tabular}{|c|c|c|c|c|c|c|c|c|c|c|c|c|c|}
\hline \multirow{2}{*}{$\begin{array}{l}\text { 右 } \\
\text { 堅 } \\
(8)\end{array}$} & \multirow{2}{*}{ 名 } & \multirow{2}{*}{ 年 } & \multirow{2}{*}{ 性 } & \multirow{2}{*}{$\begin{array}{l}\text { 造影㨈注 } \\
\text { 入量 }\end{array}$} & \multirow{2}{*}{ 撮影体位 } & \multirow{2}{*}{$\mid \begin{array}{l}\text { 腎孟の } \\
\text { 形態 }\end{array}$} & \multicolumn{2}{|c|}{ 腎杯数 } & \multirow{2}{*}{ 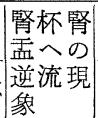 } & \multicolumn{4}{|c|}{ 腎杯, 腎需排泄時間 } \\
\hline & & & & & & & 大腎杯 & 小腎杯 & & 上腎杯| & |中腎杯 & 下腎杯 & 腎 孟 \\
\hline 1 & M. $\mathrm{H}$ & 35 & 우 & $\begin{array}{c}* 60 \% \mathrm{UM} \\
10 \mathrm{cc}\end{array}$ & 仰臥位 & 漏斗状 & 2 & 8 & $\begin{array}{c}\text { 上晫杯 } \\
(+)\end{array}$ & $5^{\prime}$ & $2^{\prime}$ & $5^{\prime}$ & $2^{\prime} 30^{\prime \prime}$ \\
\hline 2 & F. K & 38 & $\hat{0}$ & $\begin{array}{l}60 \% \mathrm{UM} \\
10 \mathrm{cc}\end{array}$ & 仰臥位 & 漏斗状 & 2 & 6 & $(-)$ & $4^{\prime} 30^{\prime \prime}$ & $3^{\prime}$ & $2^{\prime}$ & $3^{\prime}$ \\
\hline 3 & N. E & 65 & $\hat{0}$ & $\begin{array}{l}60 \% \mathrm{UM} \\
10 \mathrm{cc}\end{array}$ & 立位 & 長方形| & 2 & 8 & $(-)$ & $1^{\prime} 45^{\prime \prime}$ & $1^{\prime}$ & $3^{\prime} 30^{\prime \prime}$ & $2^{\prime} 30^{\prime}$ \\
\hline 4 & T. $\mathrm{M}$ & 40 & $\hat{o}$ & & 立位 & 漏斗状 & 2 & $\dot{7}$ & $(-)$ & $2^{\prime}$ & $2^{\prime} 35^{\prime \prime}$ & $3^{\prime}$ & $1^{\prime}$ \\
\hline 5 & K. Y & 30 & 우 & $\begin{array}{l}60 \% \mathrm{UM} \\
12 \mathrm{cc}\end{array}$ & 仰臥位＜wide>＜wide>立位 & 漏斗状 & 2 & 6 & $\begin{array}{c}\text { 上腎杯 } \\
(+)\end{array}$ & $1^{\prime} 30^{\prime \prime}$ & $3^{\prime} 30^{\prime \prime}$ & $4^{\prime}$ & $2^{\prime}$ \\
\hline 6 & W. T & 35 & $\hat{\delta}$ & $\begin{array}{l}60 \% \mathrm{UM} \\
10 \mathrm{cc}\end{array}$ & 仰臥位－立位 & 漏斗状 & 2 & 6 & $(-)$ & $1^{\prime} 30^{\prime \prime}$ & $3^{\prime} 30^{\prime \prime}$ & $4^{\prime}$ & $4^{\prime}$ \\
\hline 7 & N. H & 63 & $\hat{\delta}$ & $\begin{array}{l}75 \% \mathrm{UM} \\
10 \mathrm{cc}\end{array}$ & 仰臥位－立位 & 漏斗状 & 2 & 7 & $(-)$ & $1^{\prime}$ & $1^{\prime} 30^{\prime \prime}$ & $3^{\prime} 30^{\prime \prime}$ & $1^{\prime} 30^{\prime}$ \\
\hline 8 & K. R & 41 & 우 & $\begin{array}{l}60 \% \mathrm{UM} \\
10 \mathrm{cc}\end{array}$ & & 漏斗状 & 2 & 7 & $(-)$ & $1^{\prime} 30^{\prime \prime}$ & $4^{\prime}$ & $3^{\prime} 30^{\prime \prime}$ & $3^{\prime}$ \\
\hline \multirow{2}{*}{$\begin{array}{l}\text { 左 } \\
\text { 腎 } \\
(7)\end{array}$} & \multirow{2}{*}{ 名 } & \multirow{2}{*}{ 年 } & \multirow{2}{*}{ 性 } & \multirow{2}{*}{$\begin{array}{l}\text { 造影剤注 } \\
\text { 入量 }\end{array}$} & \multirow{2}{*}{ 撮影体位 } & \multirow{2}{*}{$\mid$\begin{tabular}{|l|} 
堅盘の \\
龍
\end{tabular}} & \multicolumn{2}{|c|}{ 腎杯数 } & \multirow{2}{*}{$\mid \begin{array}{l}\text { 腎杯腎 } \\
\text { 衁へ泣流現 } \\
\text { 像 }\end{array}$} & \multicolumn{4}{|c|}{ 腎杯, 腎孟排泄時間 } \\
\hline & & & & & & & 大䝳杯 & 小腎杯 & & 上腎杯| & 中腎杯 & 下腎杯 & 腎 盖 \\
\hline 1 & o. T & 40 & $\hat{0}$ & $\begin{array}{l}60 \% \mathrm{UM} \\
10 \mathrm{cc}\end{array}$ & 仰臥位－立位 & 漏斗状 & 2 & 8 & $(-)$ & $1^{\prime}$ & $2^{\prime}$ & $3^{\prime} 30^{\prime \prime}$ & $1^{\prime} 30^{\prime}$ \\
\hline 2 & K. Y & 55 & 우 & $\begin{array}{l}60 \% \mathrm{UM} \\
10 \mathrm{cc}\end{array}$ & 仰臥位一立位 & 漏斗状 & 2 & 9 & $(-)$ & $1^{\prime} 30^{\prime \prime}$ & $2^{\prime} 30^{\prime \prime}$ & $2^{\prime} 30^{\prime \prime}$ & $2^{\prime} 30^{\prime}$ \\
\hline 3 & E. S & 60 & $\hat{o}$ & $\begin{array}{l}60 \% \mathrm{UM} \\
10 \mathrm{cc}\end{array}$ & 仰臥位－立位 & 漏斗状 & 2 & 8 & $(-)$ & $1^{\prime} 30^{\prime \prime}$ & $3^{\prime}$ & $5^{\prime}$ & $2^{\prime} 30^{\prime}$ \\
\hline 4 & T. G & 55 & $\hat{o}$ & $\begin{array}{l}60 \% \mathrm{UM} \\
10 \mathrm{cc}\end{array}$ & 仰臥位 & 長方形 & 2 & 8 & $(-)$ & $4^{\prime}$ & $3^{\prime} 30^{\prime \prime}$ & $3^{\prime} 30^{\prime \prime}$ & $3^{\prime}$ \\
\hline 5 & H. $\mathrm{M}$ & 40 & 우 & $\begin{array}{l}60 \% \mathrm{UM} \\
10 \mathrm{cC}\end{array}$ & 仰臥位 & 漏斗状 & 2 & 8 & $\begin{array}{c}\text { 中腎杯 } \\
(+)\end{array}$ & $3^{\prime} 30^{\prime \prime}$ & $3^{\prime}$ & $4^{\prime}$ & $3^{\prime}$ \\
\hline 6 & $\mathrm{~S} \cdot \mathrm{H}$ & 29 & 우 & $\begin{array}{l}60 \% \mathrm{UM} \\
10 \mathrm{cc}\end{array}$ & 仰臥位 & 漏斗状 & 1 & 7 & $(-)$ & $3^{\prime}$ & $2^{\prime} 30^{\prime \prime}$ & $2^{\prime} 30^{\prime \prime}$ & $3^{\prime}$ \\
\hline 7 & N. H & 63 & $\hat{o}$ & $\begin{array}{l}60 \% \mathrm{UM} \\
10 \mathrm{cc}\end{array}$ & 仰臥位－立位 & 漏斗状 & 2 & 9 & $(-)$ & $1^{\prime} 30^{\prime \prime}$ & $2^{\prime} 30^{\prime \prime}$ & $3^{\prime} 30^{\prime \prime}$ & $2^{\prime} 30^{\prime}$ \\
\hline
\end{tabular}




\begin{tabular}{|c|c|c|c|c|c|c|c|c|c|c|c|c|c|c|c|c|}
\hline 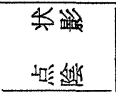 & 士 & I & I & I & I & I & I & I & I & I & I & \pm & I & I & I & I \\
\hline 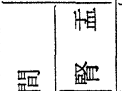 & ì & $\infty$ & $\infty$\begin{tabular}{l|}
4 \\
$\infty$ \\
$\infty$
\end{tabular} & के & i & \begin{tabular}{ll|} 
& 4 \\
0 & \multicolumn{4}{|c}{}
\end{tabular} & io & is & is & के & co & ลे & ; & in & ¿ & 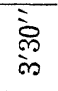 \\
\hline 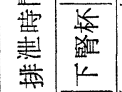 & is & 许 & $\infty$\begin{tabular}{ll|}
4 & 4 \\
$\infty$ & $x$
\end{tabular} & is & $\infty \begin{array}{ll}4 \\
\infty\end{array}$ & ì & io & 商 & 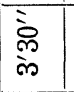 & i & i & के & io & के & $\infty$\begin{tabular}{l|}
\multicolumn{1}{|c|}{} \\
$\infty$
\end{tabular} & iे \\
\hline 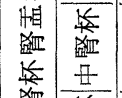 & $\begin{array}{l}\text { के } \\
\text { ஸे }\end{array}$ & ir & 天 & is & is & ì & के & ì & is & के & के & ตे & i & is & के & $\begin{array}{l}\text { हे } \\
\text { के } \\
\text { iे }\end{array}$ \\
\hline 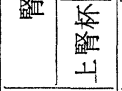 & के & ì & is & ڤે & is & 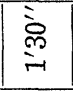 & ஸे & 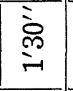 & के & के & is & ì & ì & $\begin{array}{l}\text { ڤे̀ } \\
\text { స̆ }\end{array}$ & के & के \\
\hline 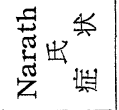 & Ð & ‡ & ક & ક & Ð & ક & ક & I & I & I & I & I & I & I & I & I \\
\hline 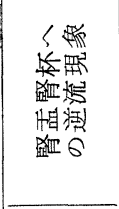 & I & I & I & I & 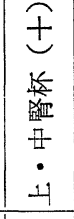 & 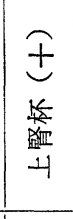 & I & 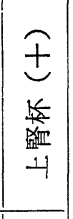 & I & I & 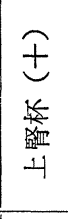 & $\begin{array}{l}\underset{士}{ \pm} \\
\text { 魦 } \\
-4\end{array}$ & 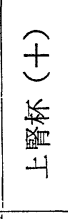 & 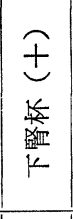 & I & I \\
\hline 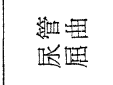 & 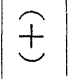 & 莑 & I & ‡ & $\stackrel{I}{I}$ & I & \pm & I & I & I & I & I & I & I & I & I \\
\hline 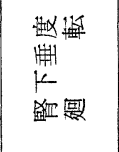 & $H$ & 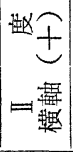 & $\begin{array}{l}\text { 连 } \\
\text { 一雷 } \\
\text { 遇 }\end{array}$ & 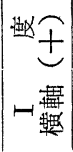 & I & I & 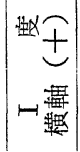 & I & I & I & I & I & I & I & I & I \\
\hline 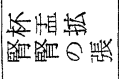 & 士 & 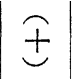 & ક & ‡ & ‡ & 莑 & $\stackrel{I}{I}$ & ‡ & ‡ & † & I & Ð & ‡ & I & I & I \\
\hline 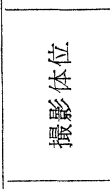 & 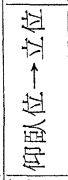 & 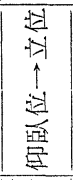 & $\forall \forall$ & 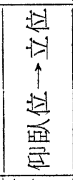 & 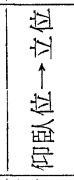 & $\begin{array}{l}\forall \forall \\
\forall \forall\end{array}$ & 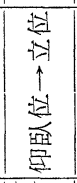 & 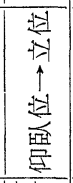 & 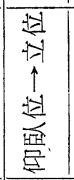 & 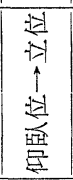 & $\begin{array}{l}\forall \forall \\
\forall \forall\end{array}$ & 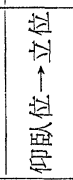 & 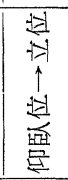 & 画 & $\begin{array}{l}\forall \forall \\
\forall \forall 1\end{array}$ & 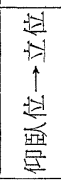 \\
\hline 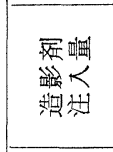 & $\begin{array}{l}\sum_{1} \\
P \\
P \\
0 \\
0 \\
0 \\
0 \\
* \\
*\end{array}$ & 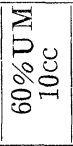 & $\begin{array}{l}\sum_{i} \\
p 0 \\
000 \\
80 \\
80\end{array}$ & $\mid \begin{array}{l}\sum_{1} \\
p 0 \\
80 \\
80 \\
8\end{array}$ & 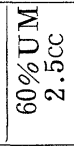 & $\begin{array}{l}\sum_{i} \\
p \\
\rho \\
00 \\
80 \\
80\end{array}$ & 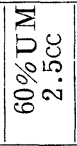 & $\mid \begin{array}{ll}2 & \\
0 & 0 \\
0 & 0 \\
0 & 0 \\
8 & 0 \\
6\end{array}$ & 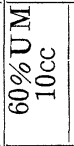 & $\mid$\begin{tabular}{l|} 
\\
$b$ \\
$p$ \\
20 \\
80 \\
8
\end{tabular} & 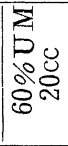 & 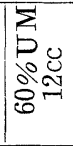 & 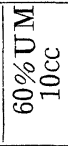 & 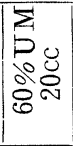 & 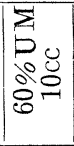 & $\mid \begin{array}{l}\sum_{1} \\
\dot{b} \\
0 \\
0 \\
0 \\
0\end{array}$ \\
\hline 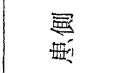 & HH & 4 & 4 & $1+$ & iH & H & HH & $H$ & 迎 & H & HH & $H$ & $1 !$ & 15 & $H$ & HH \\
\hline$\#$ & of & of & $\leftarrow 0$ & Ło & $\leftarrow 0$ & $\leftarrow 0$ & $\vdash 0$ & of & «o & $\vdash 0$ & $\leftrightarrow 0$ & OH & $\leftarrow 0$ & $\leqslant 0$ & $\leftrightarrow 0$ & $\leftarrow 0$ \\
\hline \multirow[t]{3}{*}{ सम } & $\vec{F}$ & ஜூ & 10 & 암 & 年 & లి & ๓⿴囗十 & 냄요 & $\stackrel{19}{\rightarrow}$ & ది & 악 & ని & 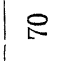 & 10 & ชู & సิ \\
\hline & م2 & E-1 & $\varpi$ & EH & 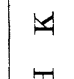 & 闻 & $\varangle$ & $\vec{r}$ & $E$ & $\varangle$ & $\Sigma$ & $\pi$ & $\forall$ & J & U & $\Sigma$ \\
\hline & $\forall$ & z & 4 & 0 & $\varpi$ & 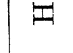 & -1 & $\forall$ & 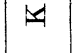 & is & $E-1$ & $\Delta$ & $\forall$ & $E-1$ & Z & 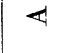 \\
\hline$\dot{\dot{z}}$ & $r-1$ & $\sim$ & $\infty$ & $\nabla$ & 10 & 0 & $\sim$ & $\infty$ & $\infty$ & 으 & $\exists$ & $\stackrel{\mathcal{I}}{-1}$ & $\stackrel{\mathscr{H}}{\rightarrow}$ & $\Xi$ & $\stackrel{10}{\Omega}$ & $\stackrel{\oplus}{-1}$ \\
\hline
\end{tabular}


た。造影郕は60\%ウロコリンMを 32 例，75\%ウロコリン Mを 4 例に使用してみたが，得られた像には濃度による 差は殆んど認められなかつた。

正常15腎の撮影成績：正常と思われた右腎 8 及び左

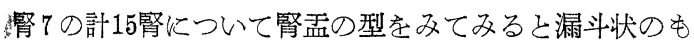
のがその大部分であつて，第 6 表に示す如く，大腎杯が

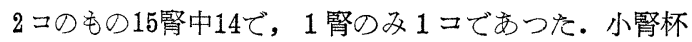

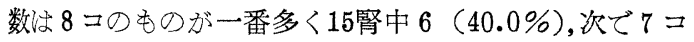
4 腎 $(26.6 \%), 6 コ 3$ 腎 $(20 \%)$ 及び 9 コ 2 腎 $(13.3$ \%)であり 7〜8コのものが多いようである. 腎盐腎杯 への逆流現象恃右需で 8 例中 2 例に及られ，いずれも上 腎杯浔められた。左腎では 7 例中 1 例中腎杯に観察さ れた.との現象と撮影体位との関係を及てみると第 6 表 に見る如く起りにくいと思われる立位でも見られる事か らあまり本現象と撮影体位との間には関係が無いようで ある。

又腎盘の緊張低下時に見られると一般炕云われている Narath 氏症状注 1 例にも認められなかつた。腎杯, 腎 孟の Emptying time 注第6表に示す如く, 全て仰卧位 で撮影した 5 例では，上腎杯で 3 分〜 5 分，中腎杯で 2 分〜 3 分 30 秒, 下腎杯で 3 分〜 5 分及び腎孟では 2 分 30 秒〜 3 分であり, 中腎杯乞腎孟の排泄時間がや>早いよ ろである.立位のみで撮影した 2 例では，上腎杯 1 分 45 秒 $\sim 2$ 分, 中腎杯 1 分 $~ 2$ 分 35 秒, 下腎杯 3 分 3 分 30 秒及び腎孟では 1 分 2 分 30 秒と仰卧位より早く, 最初 の 1 枚注仰卧位で撮影し, 1 分後の 2 枚目より立位で行 つた 8 例では, 上腎杯 1 分〜 1 分 30 秒, 中腎杯 2 分 3 分 30 秒, 下腎杯 3 分 4 分及び腎㙉 2 分〜 3 分であつ た。上上成績からみて腎怀及び腎盖内に注入せる $60 \%$ 又は75\%ウロコリンM10１2ccの排泄時間は，仰卧位で 上䐌杯 5 分以内, 中腎杯 4 分以内, 下腎杯 5 分以内及び 腎盂では 3 分以内であり, 立位で上腎杯 2 分以内, 中腎 杯 3 分以内, 下腎杯 4 分以内及び腎㙉では 3 分以内と少 し早く, 最初仰臥位で 2 枚目の撮影より立位とした場合 では上腎杯 2 分以内, 中腎杯 4 分以内, 下腎杯 4 分以内 及び腎孟では 3 分以内であつた。

腎出血16例の撮影成績：腎出血16例の左右別は第 7 表沉みる如く，左11例及び右 5 例で幾分左に多かつた。 男女別では男12例及び女 4 例であり, 年令別で見てみる と最年少29才, 最年長75才であつた。造影郕は全てウ口 コリンMを使用し, 造影剤注入時に軽い側腹部緊張感を 訴えた 2 例に $2.5 \mathrm{cc}$ ，あらかじめ腎杯，腎盂系に拡張の 及られた 2 例に $20 \mathrm{cc}$ 及び 1 例に $12 \mathrm{cc}$ 注入し, 残り 11 例に は全て両側10ccづつ注入した。撮影体位は全て仰卧位 1 例, 立位の及 4 例, 残り11例は最初仰卧位で 1 枚撮影 し，2枚目より立位で行つたものである．次に腎杯及び 腎孟に应張のみられたものは16例中11例で約 $68.7 \%$, 立 位撮影で腎下垂を認めたもの 5 例で約 $31 \%$ ありり，とれ らの下垂の程度は軽く, ろち 4 例に下垂之同時に腎臓の 横軸备旋が認められた. 又立位撮影で尿管の屈曲像を 5 例に認め，いずれも腎下垂側にみられた。 そしてこの屈 曲は腎臓の下垂が大きい程強い傾向にあつた。腎盂腎杯 への逆流現象は16例中 7 例，約 $43 \%$ に文引れ，乙れと撮

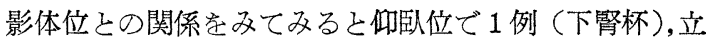
位で 2 例 (上腎杯) 及び仰臥位と立位の組合わせ撮影で 4 例（上腎杯 3 例, 上及び中腎杯 1 例）であつて, 起り にくいと思われる立位でこの現象が観察され, 且つ立位 で上腎杯に多く見られた事は興味ある。この現象は腎下 垂や尿管屈曲の見られた腎臓には 1 例も及られず，腎杯 及び腎㙉系に拡張のある例に比較的多く観察され，7例 中 5 例が㷆杯及び腎孟系に拡張のある腎臓に観察され た. Narath 氏症状は16例中 7 例に及, 万ち5 例は腎下 垂の認められた症例に，他の 2 例は腎下垂は無いが眯孟 の拡張せる症例に認められた。腎杯及び腎孟内に注入さ れた造影剂の排泄時間は全て立位の 4 例では, 上腎杯 1 分 30 秒 $\sim 5$ 分, 中腎杯 2 分 7 分, 下腎杯 3 分 8 分以 上及び腎孟で 4 分〜 8 分以上となり，仰臥位と立位の組 合わせで撮影した 11 例では, 上腎杯 1 分 30 秒 3 分, 中 腎怀 2 分 30 秒 5 分, 下腎杯 2 分 30 秒 $~ 8$ 分以上及び腎 孟で 2 分〜 6 分であつた. 尚全て仰臥位で撮影した 1 例 ではそれぞれ 2 分 30 秒, 3 分, 3 分 30 秒及び 3 分であつ た. 即与立位撮影の 4 例では, 上腎杯 5 分以内, 中腎杯 7 分以内, 下腎杯 8 分内外及び腎㙉で 8 分内外已上, 中 及び下腎杯の順に造影滆の排泄を見，正常例と比較する と幾分延長している．又仰臥位と立位の組合わせで撮影 した11例では, 上腎杯 3 分以内, 中腎杯 5 分以内, 下腎 杯 8 分内外及び腎㙉で 6 分内外であつた. 以上述べた如 く，腎杯及び腎典内に注入された造影剂は大体 5 分内外 で排泄されるが，腎杯及び腎孟像がすでに完全に消失し ているにも拘らず，1 力所腎出血側に造影滆が点状に残 る部位があり(第35図), これが最後の 8 分後の撮影に至 るフイルム全てに認められ，16例中 3 例にか つる所見を 得た. 尚これの本態は不明であるが，興味ある所見己思 われる。

腎下垂症14腎の撮影成績： 本症の左右別怯，右 6 例，両側 4 例及び左なしであるが，男女別では男女共に 
第 8 表 腎下垂者10例14腎の逆行性腎孟間接撮影成績

\begin{tabular}{|c|c|c|c|c|c|c|c|c|c|c|c|c|c|c|c|}
\hline \multirow{2}{*}{ No. } & \multirow{2}{*}{ 名 } & \multirow{2}{*}{ 年 } & \multirow{2}{*}{ 性 } & \multirow{2}{*}{ 患側 } & \multirow{2}{*}{$\begin{array}{l}\text { 造影剤 } \\
\text { 注入量 }\end{array}$} & \multirow{2}{*}{ 撮影体位 } & \multirow{2}{*}{ 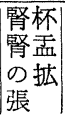 } & \multirow{2}{*}{ 堅下垂庭 } & \multirow{2}{*}{\begin{tabular}{|l} 
丞管 \\
成曲
\end{tabular}} & \multirow{2}{*}{$\begin{array}{c}\text { 腎孟腎杯 } \\
\text { 逆流現象 }\end{array}$} & \multirow{2}{*}{$\begin{array}{l}\text { Nalatia } \\
\text { 氏 } \\
\text { 症 状 }\end{array}$} & \multicolumn{4}{|c|}{ 腎杯, 腎盂排泄時間 } \\
\hline & & & & & & & & & & & & 上腎杯 & 中腎杯| & 下腎杯| & 腎孟 \\
\hline 1 & N. Z & 63 & 우 & 右 & $\begin{array}{c}* 60 \% \mathrm{UM} \\
10 \mathrm{cc}\end{array}$ & 仰臥位－立位 & $(+)$ & $\mid \begin{array}{cc}\text { III } \\
\text { 横軸 }(+ \text { 度 }\end{array}$ & $($ (W) & $(-)$ & $(+)$ & $2^{\prime} 30^{\prime \prime}$ & $4^{\prime}$ & $4^{\prime} 30^{\prime \prime}$ & $8^{\prime}$ \\
\hline 2 & W. J & 35 & $\hat{0}$ & 右 & $\begin{array}{c}60 \% \mathrm{UM} \\
10 \mathrm{cc}\end{array}$ & 仰臥位，立位 & $(+)$ & \begin{tabular}{|cc}
$\mathrm{I}$ 度 \\
横軸 \\
+
\end{tabular} & $(+)$ & $(-)$ & $(+)$ & $1^{\prime} 30^{\prime \prime}$ & $2^{\prime} 30^{\prime \prime}$ & $4^{\prime} \quad 2$ & $2^{\prime} 30^{\prime \prime}$ \\
\hline \multirow{2}{*}{3} & \multirow{2}{*}{ A. I } & \multirow{2}{*}{35} & \multirow{2}{*}{$\hat{o}$} & 右 & $\begin{array}{c}60 \% \mathrm{UM} \\
5 \mathrm{cc}\end{array}$ & 仰臥位－立位 & $(-)$ & I 度 & $(t) \mid$ & $(-)$ & $(+)$ & $1^{\prime} 30^{\prime \prime}$ & $3^{\prime}$ & $6^{\prime}$ & $4^{\prime}$ \\
\hline & & & & 左 & $\begin{array}{c}60 \% \mathrm{UM} \\
2.5 \mathrm{cc}\end{array}$ & 仰臥位 & $(-)$ & I 度 & $(+)$ & $(-)$ & $(+)$ & $1^{\prime} 30^{\prime \prime}$ & $3^{\prime}$ & $\begin{array}{l}8^{\prime} \\
\text { 以上」 }\end{array}$ & 以上 \\
\hline \multirow[b]{2}{*}{4} & \multirow[b]{2}{*}{ H. S } & \multirow[b]{2}{*}{33} & \multirow[b]{2}{*}{ 우 } & 右 & $\begin{array}{l}60 \% \mathrm{UM} \\
10 \mathrm{cc}\end{array}$ & 仰臥位－立位 & (H) & III 度 & $($ (W) & 中腎杯 $(+)$ & $(+)$ & $2^{\prime} 30^{\prime \prime}$ & $3^{\prime} 30^{\prime \prime}$ & $\begin{array}{l}8^{\prime} \\
\text { 以上 }\end{array}$ & $6^{\prime}$ \\
\hline & & & & 左 & $\begin{array}{c}60 \% \mathrm{UM} \\
10 \mathrm{cc}\end{array}$ & 仰臥位－立位 & $(H)$ & III 度 & $(+)$ & $(-)$ & $(+)$ & $2^{\prime}$ & $4^{\prime} 30^{\prime \prime}$ & $5^{\prime}$ & $\begin{array}{l}8^{\prime} \\
\text { 以上 }\end{array}$ \\
\hline \multirow{2}{*}{5} & \multirow{2}{*}{ O. M } & \multirow{2}{*}{28} & \multirow{2}{*}{$\hat{o}$} & 右 & $\begin{array}{l}60 \% \mathrm{UM} \\
20 \mathrm{cc}\end{array}$ & 仰臥位－立位 & $($ (W) & I 度 & $(+)$ & $(-)$ & $(-)$ & $4^{\prime} 30^{\prime \prime}$ & $5^{\prime}$ & $6^{\prime}$ & $3^{\prime} 30^{\prime \prime}$ \\
\hline & & & & 左 & $\begin{array}{c}60 \% \mathrm{UM} \\
20 \mathrm{cc}\end{array}$ & 仰臥位 $\rightarrow$ 立位 & $($ (W) & $\left|\begin{array}{cc}\mathbb{I I} & \text { 度 } \\
\text { 横軸 } & (+)\end{array}\right|$ & $(\mathrm{HI})$ & $(-)$ & $(+)$ & $1^{\prime} 30^{\prime \prime}$ & $6^{\prime}$ & $6^{\prime}$ & $\begin{array}{l}8^{\prime} \\
\text { 以上 }\end{array}$ \\
\hline \multirow{2}{*}{6} & \multirow{2}{*}{ O. K } & \multirow{2}{*}{31} & \multirow[b]{2}{*}{ 우 } & 右 & $\begin{array}{c}60 \% \mathrm{UM} \\
5 \mathrm{cc}\end{array}$ & 仰臥位－立位 & $(+)$ & $\begin{array}{c}\text { II } \\
\text { 横軸( } \\
\text { 十) }\end{array}$ & $($ (W) & $(-)$ & $(+)$ & $1^{\prime} 30^{\prime \prime}$ & $3^{\prime}$ & $\begin{array}{l}8^{\prime} \\
\text { 以上 }\end{array}$ & $6^{\prime}$ \\
\hline & & & & 左 & $\begin{array}{c}60 \% \mathrm{UM} \\
3 \mathrm{CC}\end{array}$ & 仰臥位 $\rightarrow$ 立位 & $(-)$ & II 度 & $(\mathrm{W})$ & $(-)$ & $(+)$ & $\begin{array}{l}8^{\prime} \\
\text { 以上 }\end{array}$ & $\begin{array}{l}8^{\prime} \\
\text { 以上 }\end{array}$ & $\begin{array}{l}8^{\prime} \\
\text { 以上 }\end{array}$ & 以上 \\
\hline 7 & S. M & 42 & 우 & 右 & $\begin{array}{l}75 \% \mathrm{UM} \\
10 \mathrm{cc}\end{array}$ & 仰臥位 $\rightarrow$ 立位 & (H) & $\mid \begin{array}{cc}\mathrm{I} & \text { 度 } \\
\text { 横軸 } & (+)\end{array}$ & (W) & $(-)$ & $(-)$ & $6^{\prime}$ & $15^{\prime}$ & $\begin{array}{c}15^{\prime} \\
\text { 以上 }\end{array}$ & $\begin{array}{l}15^{\prime} \\
\text { 以上 }\end{array}$ \\
\hline 8 & S. T & 47 & 우 & 右 & $\begin{array}{l}75 \% \mathrm{UM} \\
10 \mathrm{cc}\end{array}$ & 仰臥位 $\rightarrow$ 立位 & $(+)$ & 縰軸 $(+$ 度 & $(\mathrm{HI})$ & 上腎杯 $(+)$ & $(-)$ & $2^{\prime} 30^{\prime \prime}$ & $4^{\prime} 30^{\prime \prime}$ & $\begin{array}{c}10^{\prime} \\
\text { 以上 }\end{array}$ & $\begin{array}{l}10^{\prime} \\
\text { 以上 }\end{array}$ \\
\hline 9 & H. K & 47 & $\hat{\delta}$ & 右 & $\begin{array}{c}60 \% \mathrm{UM} \\
2.5 \% \\
\end{array}$ & 仰臥位－立位 & $(+)$ & 度 & $($ H) & 上䐌杯 $(+)$ & $(-)$ & $3^{\prime} 30^{\prime \prime}$ & $4^{\prime} 30^{\prime \prime}$ & $5^{\prime}$ & $4^{\prime}$ \\
\hline 10 & $\mid \mathrm{I} \cdot \mathrm{K}$ & 21 & $\hat{0}$ & 右 & $\begin{array}{c}60 \% \mathrm{UM} \\
10 \mathrm{cc}\end{array}$ & 仰臥位＜wide>－立位 & $(-)$ & $\begin{array}{c}I_{\text {横軸 }} \text { (度 } \\
+\end{array}$ & $(+)$ & $(-)$ & $(-)$ & $2^{\prime}$ & $3^{\prime}$ & $2^{\prime} 30^{\prime \prime}$ & $3^{\prime}$ \\
\hline
\end{tabular}

$* \mathrm{UM}=$ Urokolin-M

5 例づつで, 年令は最年少 21 才及び最年長 63 才であつ た。造影剂は60\%ウロコリンM10cc注入したもの5 腎, $20 \mathrm{cc}$ 注入したもの 2 腎， $5 \mathrm{cc} 2$ 腎，2.5cc 2 腎及び $3 \mathrm{cc}$ 1 腎であり，75\%ウロコリンM10cc注入したもの 2 㱟で ある.このように造影郕の注入量が異るのは, 注入中に 少しでも側腹部に緊張感を訴えた場合にはととで注入を 中止したためである.撮影体位は 1 腎の及最初の 2 枚字 仰臥位で行い, 他の13腎は最初の1枚を仰卧位で撮影を 行い, 以後 2 枚目より立位で行つた。腎杯及び腎㙉系に 拡張を認めたもの14腎中10腎で約71\%であつた。腎下垂 の程度であるが, Woodruff \& Sherer の分類によれば 第 3 度のもの14腎中 4 腎，第 2 度 4 腎及び第 1 度 6 腎で あつた（第 8 表).又これら14腎中 7 腎 $(50 \%)$ に下垂に 伴う腎呬旋が観察された。尿管屈曲注14腎全てにみら れ, 腎下垂が強く, 迴旋字伴う腎臓に屈曲が強く認めら
れた。腎監杯への逆流現象注14腎中 3 腎に及られ，出 現部位は上腎杯 2 及び中腎杯 1 腎にみられた。撮影体位 が立位であるにも拘らず，上中腎杯丈にみられ，下腎杯 にみられなかつた事な大変興味ある事であつて, 腎臓の 下垂状態や尿管屈曲等と以直接関係が無いようである. Narath 氏症状注14腎中 9 腎 $(64.2 \%)$ 飞久られ，腎下 垂の程度の強いものに現れる傾向がある(第 8 表).腎杯 及び腎需内に注入された造影剂の排泄時間注第 8 表にみ る如 $く$, 上腎杯で最短 1 分 30 秒, 最長 8 分以上であるが 大体 2 分〜 4 分, 中腎杯では最短 2 分 30 秒, 最長 15 分て 大体 3 分〜 6 分, 下腎杯では最短 2 分 30 秒, 最長 15 分 以上さかなりその時間に巾の開きがあり, 大体 4 分〜 8 分及び腎盎では最短 2 分 30 秒, 最長 15 分以上で大体 4 分 〜8分であつた.これらの排泄時間注上珡杯が一番早 く, 次で中, 下腎杯の順であつて正常例と比較してみ 
るとやはり幾分延長している.そして下垂の程度の強 いもの, Narath 氏症状の認められたものに延長する傾 向を示した. 又上, 中腎杯に比べて下腎杯及び腎盎の排 泄時間が延長していた。

\section{VI 総括並びに考按}

高圧撮影法は周囲とのコントラストにあまり差を生じ ないため, 軟部組織主体とする泌尿器科頒域には殆ん ぞ利用されて来なかつたが, 撮影裝置の改善, 光学機械 の進歩, フイルムの質の向上, 散乱線除去裝置の改善及 び高濃度血管造影訪の出現等で, 高圧の利点を生かして 従来のレ線像に匹敵する写真撮影に成功した。

高圧撮影法とは一般に用いられているょり高い電圧, 即ち $100 \mathrm{kV}$ 以上の電圧を用いる撮影法であるが, 高電 圧ではフイルムにカブリが増してかえつて良くないと云 う理由からあまり応用されなかつた.しかしこの数年来 の研究とこれに伴う診断用裝置, レ線管球の進歩及びて れらカブリの原因となる散乱線除去格子の進歩は従来の 高圧撮影の欠点を克服したばかりでなく, 畫質に於いて も低圧撮影では得られない診断領域を開発するにいた り, 現在では特殊撮影の意味ばかりでなく, 種くの撮影 に応用されるょうになつて来た ${ }^{77}$. 高圧撮影法の特徵柱 従来の低圧撮影法乙比較して次の如きものである ${ }^{78)}$.

1）管電圧が高くなると透過性の高いレントグン線が発 生する. 従つて被写体を透つてフイルムに感光作用を及 汸すレ線量が多くなり, 撮影時間の短縮, 管球負荷の減 少, 小焦点使用の可能性等の利点を伴う . 即与撮影時間 の短縮は被曝線量の軽減に有利であつて, 又小焦点の使 用で鮮明な畫像を期待し得る訳である，2）身体各組織 の差によるレ線の透過性の差が少くなる。従来の低管 電圧では, 特に骨と筋肉等軟部組織との間にレ線吸収率 の差が著しく, 骨陰影が強く現われていた。所が管球に 高い電圧が加わると骨のレ線吸収率が著明に小さくな り，骨陰影は消裉して来る. この事は撮影対象によつて は障害陰影の消裉意味する. この性質を利用して特に 第11 12肋骨と重なる腎上極の病変, 椎体横突起と重な る尿管陰影及び恥骨や坐骨と重なる尿道斜位撮影等の陰 影を読影するのに好都合であつて，撮影にあたり食事制 限, 下剂投与及び浣腸等の前処置も全く不必要になつ て来る。3）上線写真に同じ黒化濃度を得る為の必要 $\mathrm{mA} / \mathrm{sec}$ 以管電圧が高くなると共に著しく減少し, この 事は被検者の被曝線量の減少にも役立ち, 連続撮影法等 に応用されたり，又放射線障害等を考慮に入れる巨小児 の撮影飞有利であると述べている人もある．4)高圧撮影
像はコントラストの低下をみるが，寛容度が広くなる。 各組織間の吸収率の差が少なくなる為, レ線像は主とし て厚さの差が写真の濃度差を現わす事になる，そして骨 己歕部組織間の陰影差が著しく少なくなつてくる.か〉 る高圧像法従来の低圧像に比して全般的にコントラスト の低下所見として感じられるが（第 4 及び第 5 図）, 然し 空気と軟部組織間のコントラストは殆んご変らないし, 従来濃い一つの陰影として示されていたものの内部構造 をもある程度示現してくれるので目的によつては診断上 の利点となり, 更に肥満者の撮影も容易となつて体厚の 差による撮影条件も殆んご一金して調節を簡略化し得る 特徵がある．この点集団検診等に有利である，5）管電 圧が高くなると散乱X線が増加しててれがカブリの原因 となり, 高圧撮影法の最大の久点である. 如何にしてて れを除去するかが問題で適当な格子を用いるとか(グリ ッド法),被写体とフイルムとの間を離すかして散乱線の フイルムヘの影響を少なくする工夫をする必要がある. このような工夫をする事により今や高圧撮影法沈特 徵妾充分生かして, 臨床に応用されるようになつた。以 上の如き特徵有する高圧撮影法著者注上部尿路撮影 认応用し, 泌尿器科領域にも高圧は充分利する所がある 事を認めた. 即ち著者は上部尿路の単純撮影, 腹膜後腔 気体撮影, IVP 及び RP に高圧を用いてみたが, 腎上 極さ重なる第11〜12肋骨の消裉，尿管陰影乞重なる椎体 横突起の消裉及び腸内固形物陰影の消裉等はレ線像の読 影上かなり好都合である.又空気と骨組織及び軟部組織 この間には密度の差が格段と異るので，乙れらの間には 充分なレ線減弱能の違いがあつて ${ }^{79)}$, 空気は高圧で周囲 こ明膫なコントラストがつくので泌尿器領域で空気を用 いるレントゲン撮影法, 例えば腹膜後胿気体撮影法, 腎 孟気体撮影法及び膀胱気体撮影法等に応用してみたら従 来の撮影では得られない利点があるものと思われる。

間接撮影法さは身体安透したレントグン線を一度螢光 板上に受け可視像として，乙れを更に小型カメラで縮小 してフイルムに撮影する方法で，乙のカメラは本邦では 一般にレンズ写真機が用いられているが，最近鏡写真機 が登場し注目されている ${ }^{80)}$. 間接撮影法注直接撮影法に 比較してレ線撮影をより簡単に経済的に行えると云う点 にその意義があり, 更にフイルムが $35 \mathrm{~mm}$ 判か $60 \mathrm{~mm}$ 判であ る事が多く, 連続的撮影が出来る利点があるが, 得られ た像の鮮鋭度が直接撮影像に劣ると云う久点がある・し かし撮影裝置の改善, 光学機械の進歩, フイルムの質の向 上等で殆んぞ直接撮影像に匹敵する鮮明な間接撮影像を 
得る事が出来るようになつて来た．間接撮影は操作が簡 単で廉価であるから多数集団の検診に利用されている. そして多数の異つた体厚の被検者をレ線撮影するのであ るから濃度は不揃になりがちである。そこでこれを少く するために電圧を高圧となし, 多数の集団を何処に於い ても容易に撮影が出来るように，ままり電源事情に左右 されない蓄電器放電式裝置が間接撮影裝置にとり入れら れた.この結果, 間接撮影法は何処に於いても手軽に利 用されるようになつた。著者の応用した間接撮影裝置は 第 1 表に示す如く高圧撮影の出来るキヤノンカメラを用 いたレンズ写真機式であつて, この蓄電器放電式裝置定 有する間接撮影裝置である.

著者が本裝置を用いて高圧間接撮影を実施した成績を まとめて各撮影法別に述べると次の如くである.

（1）腹部単純間接撮影法：正常例 5 例, 右腎結石 2 例, 左腎結石 1 例, 馬尾神経腫湟 1 例及び右腹部腫瘤 に行つた腹膜後腔気体撮影法 1 例の計10例について行つ た(第 3 表).管電圧が高圧になる事によつて軟部組織で ある腎臟の輪郭, 腸腰筋陰影のコントラストが惡くなり 周囲との間に濃度差が無くなり, 腹膜後腔気体撮影法を 除く大部分が腎蔵及び腸腰筋陰影が不明瞭であつた。こ の点低圧直接撮影像に劣るが，しかし腸内容とくに腸内 固形物は殆んご消褪して撮影にあたり下剂投与，食事制 限及び浣腸等の前処置が不必要となり患者に与える負担 がそれ丈少い事になる．従つて，との事は何処に於いて も簡単に手軽にレ線撮影を行う事の出来る大事な要素で も㐫つて，特に大多数の患者を集団的に検査するのに大 変好都合である.次に腸内ガスであるが,第 3 表にみる如 く直接撮影像已殆えで変らない位良く描出されている. 高圧撮影では周囲組織の陰影が淡くなり各組織間に濃度 差が無くななつてガス陰影は直接撮影像よりも鮮明に描 出ささている. この性質安利用して腹膜後腔気体撮影法 に高圧間接撮影法定用いてみたが，第 9 図にみる如く 空気と周囲組織とのコントラストが良く, 腎臓の輪郭及 び腸腰笳陰影も明膫渵出されている.そして骨陰影も 比較的淡くなつていて一層読影に好都合である. 督結石 症 3 例认本影影法を応用して及たが, 結石陰影㥀接撮 影像に比べ全体として淡く描出されるが立体性が陰影上 に現れ, 被検者の体位を变え撮影し結石陰影の形態学立 体的に観察し得た. 馬尾神経腫瘍の 1 例では直接撮影像 で仙骨に腫瘍による陰影欠損が認められたもので, てれ に対して本撮影法そ試みた所, 直接撮影像とあまり変ら ない陰影を描出し得た. 以上の事から従来の低圧直接単
純像乙高圧間接単純像己学比較してみる己第 2 表の如く であつて, 軟部組織を主体とする泌尿器科領域では腹部 単純撮影に高圧間接撮影を用いてもあまり効果が期待出 来ないが, 骨陰影の消裉, 腸内ガスと周囲組織との間に コントラストに大きな差がある性質を利用して腎盂気体 撮影法, 膀胱気体撮影法, 腹膜後腔気体撮影法及びこれと 断層撮影法との併用等に応用してみると，従来の低圧撮 影像では得られなかつた効果市あるものと思われる。 本法を以つて值接撮影像に代える訳に山行かないが, routineつレ線像で病的陰影と思われる所見を得た場合， 直接撮影法では撮影枚数に経済的にも制限があり，か> る時に本法を以つて連続的に10数枚撮影して病的陰影を 立体的に追及するのには充分意義あるものと思う。

（2）静注性腎孟間接撮影法：正常例 4 例，腎出血 3 例, 腎腫瘍 1 例, 腎結核 1 例, 腎結核の疑 2 例, 腰部腎变 位 1 例, 腎孟腎炎 3 例及び水腎症 2 例の計 17 例に本法を 行つた。これ等の中より代表的な症例を図示し, 正常と 思われた右 6 腎, 左 6 腎の計 12 腎について腎杯, 腎酉及 び尿管像学観察したが正常例以外の13例法全て routine のレ線督孟像で病的陰影を認めたものであつて，てれら 病的陰影を立体的に観察する目的で本法を用いた。

前処置：撮影飞あたり, 下剂投与, 食事制限及び浣 腸等の前処置を全例に施行しなかつたにも拘らず，何ら 読影に支障を来さなかつた. この事はレ線撮影をより簡 単にし, 何時, 何処に於いても造影剤さえ静注すると堅 瑥像が得られる訳で，乙れも高圧間接撮影法の利点の1 つであつて, 今後集団を対象として腎㙉像を観察するよ ろな場合, 大変好都合である.

造影剂及び注入量：現在用いられている造影剂は全 て有機ヨード剤であつて, 大別して Pyridine 核に $2=$ のヨードを有するものと, Benzene 核に 3 コのヨード を有するものと 2 種類があつて, 前者に属するものに Urocelektan B, Sugiuron, Neo-Skiodan, Diodrast 及 び Pyraceton 等があり,後者に属するものには Urokon, Urokolin, Diaginol, Urografin 及び Hypaque 等があ る ${ }^{81)}$. 著者怡後者に属するウロコリンMとウログラフイ ンを使用した。即 $560 \%$ ロコリンM20ccを 1 例に, 76 \%ウログラフイン 20ccを1例に，76\%ウログラフイン $20 \mathrm{cc} 1$ 例に用いてみたが, 得られた腎㙉像は薄く, 読 影が困難であつた。そとで75\%ウロコリンMを30〜 40cc を 2 例に静注して撮影を行つた所，かなり鮮明な腎孟像 を得た。しかし $85 \%$ ウロコリンMの試供を得て更に鮮明 な腎盂像の描出に成功した. 注入量牥成人量孛 $40 \mathrm{cc}$ とし て体格により適宜増減したが13例全例に85\%ウロコリン 
Mを25〜40cc使用して満足せる腎孟像得た。本撮影法は 高圧で, しかも間接撮影法であるため高濃度の血管造影 版を比較的大量に静注しなければ鮮明な腎孟像を描出す る事が出来ない。

圧迫帯：IVP は腎藏の排泄機能, 腎杯, 腎孟の形 態及び尿路の通過状態等を観察するレントグン検査法 で，圧迫帯を使用する己尿管全走行の状態を同時に描出 し得ない欠点がある．腎蔵の自然な状態を観察するため には腹部に造影剤の流出を防ぐ圧迫帯等を使用しない力 がより目的にかなつている訳であるが，圧迫帯が無けれ 悎影剂が流れてそれ丈造影が惡い事になる．従つて高 濃度の造影剤安比較的大量に使用しなければならない。 圧迫帯を使用して得られた腎盂像は幾分应張された像学 呈して来るので, 腎臓の自然の姿をみるにはやはり無圧 迫撮影の方が良いように思われる．著者は17例中15例を 無圧迫で行つたが得られた腎㙉像はかなり鮮明であつ た. 又無圧迫でも特に頭部を下げて骨盤高位等の体位は とらず，水平位で行つたり，途中から立位にしたりして 撮影を行つた。

撮影体位，時間及び枚数： 全て仰臥位で撮影したも の 6 例, 最初办 56 枚目迄, 即与造影剤静注後 9 分迄を 㓛卧位とし，以後立位となして行つたもの11例である。 又疾患によつては撮影台上で体位を变えて色くの方向か ら撮影を行つた。撮影時間は造影剤静注終了直後, 仰卧 位で 1 枚撮影し, 以後 1 分, 3 分, 5 分, 7 分, 9 分之 2 分間隔で11枚撮影した。一般に 2 分間隔で20分後迄撮 影したが, 17分後で撮影を終つたもの, 又排泄の遅れて いるような場合には撮影時間を 5 分間隔にしたり，或は 10分間隔としたりして撮影した.17例の撮影成績からこ れら撮影体位及び時間や枚数を検討してみると，腎孟， 腎杯及び尿管の形態を自然の状態として観察する場合は 高濃度造影剂を比較的大量に, 例えば $35 \sim 40 \mathrm{cc}$ 成人量 として用い無圧迫で仰臥位のみの撮影が良く，腎臓の起 立性反応の有無, 腎臓の下垂及び上部尿路の通過障害等 を観察する場合注仰臥位々立位の組合わせで撮影すると 良いように思われる，又病的陰影を認めた場合，患側を 下にして患者の背面と撮影台とのなす角度を種々変えて 斜位撮影を行う事によつてこれら病的陰影の形態を立体 的観察する事が出来る. そして高圧撮影であるため, 体位を迴転しても得られる像が体の厚さにより著しく変 化を来さない利点がある。撮影時間は造影衶が高濃度で あるため静注終了迄約 $2 \sim 3$ 分要するが，造影剂静注後 1分ですでに腎杯の出現をみるものも西るが，充満が惡 い. 5 分後では餭杯，腎盂及び尿管像が鮮明に現れてお
り，充分細部に渡つて読影する事が出来る。そして仰卧 位撮影では 9 分〜 13分後が最も濃い腎杯, 腎孟像を得, 15分以後はこれらの陰影は漸次薄れて行く. 仰卧位已立 位乞を組合わせて撮影した場合，即ち11分後から立位己 なして撮影すると，腎杯，腎孟像腎臓の起立性反応の ため正常例では造影剂が腎盂外に排泄されて消失する事 を認めた。

正常乞思われた右 6 腎及び左 6 腎の計 12 腎，につい てみてみると，第 5 表に示す如く腎杯腎孟及び尿管の 出現時間は, 仰臥位で造影剂注入後 1 分ですでに腎杯 像の出現しているものが 4 腎（33\%）あるが，造影郕 の充満は不充分である. 次で 2 分後 2 腎 $(16.6 \%), 2$ 分 30 秒 1 腎 $(8.3 \%), 3$ 分後 4 腎 $(33 \%)$ 及び 5 分後 1 腎 $(8.3 \%)$ であり, 腎杯出現時間は大体 2 分〜 3 分後 と見て良い. 腎孟像はこれより少し遅れ，最も早いもの は 2 分 30 秒後で出現している. そして 2 腎に 2 分 30 秒て

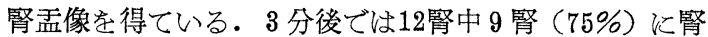
孟像を認め，5分後に 1 腎 $(8.3 \%)$ 飞認めている. 腎 孟の出現時間は正常の場合大体 3 分と及て良い。次に尿 管の出現時間であるが，更に遅れて最も早いもので 3 分 後, 即5 4 腎 $(33 \%)$ 飞 3 分後尿管像安認め，4 分後 1 腎 $(8.3 \%), 5$ 分後 5 腎 $(41.6 \%)$ 及び 7 分後 2 腎 (16 $.6 \%)$ であつた. 尿管の出現時間 と思われる。乙れ等腎杯，腎孟及び尿管像注大体造影剂 静注後 3 分で読影可能であるが，やはり造影揄の充満が 不充分であつて細部に渡つて読影する事が出来ない。し かし 5 分後に至るとこれらの陰影はかなり鮮明になつて 描出されて来る.そして時間がたつにつれて漸次造影郕 の充満を增し 9 分 13分後に最高に達し, 15 分以後次次 第に陰影は薄れて行く：しかし最後に撮影せる20分後像 に於いても腎杯に少量の造影郕を残すものもあつた。

以上の事から著者は仰卧位のみで撮影する時梳造影胴 静注後 1 分, 5 分, 9 分及び15分の 4 枚撮影, 最初仰卧 位で撮影し，途中で立位にして撮影する場合は，1分，5 分, 9 分を仰卧位て撮影し11分後に撮影台を立位さなし て 1 枚撮影し, 更に15分後の計 5 枚の撮影で充分目的定 達し得るものと思われる. 造影訪注入後 1 分で撮影する のは腎杯の出現時間を観察するためであつて, 腎機能が 良い時にはこの 1 分で腎杯像の出現をみる。レ線撮影時 の被曝線量の事も考えると，みだりに撮影枚数を增ずべ きではなく，この4〜5枚の撮影なら全く問題ではな い. この被曝線量は諸家によつて論じられているが，多 くの報告をみてみると大体20２5r が限度のようである 
が，著者の用いた裝置では 1 枚の撮影にあたり瞬間 1.2

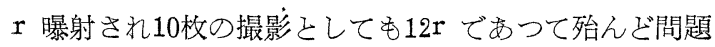
そならないものと思わ机る。

腎杯，腎㙉及び㲾管の運動についてみてみると，最近 これに関する研究が螢光倍増管を使用してレ線嵌畫撮影 を行つたり, 又ビジコンカメラと接続させてテレビ撮影 s2) 83) を行つて腎杯, 督孟及び尿管の運動を詳細に観察し ているが, 著者の 2 分間隔の撮影ではこれ等の運動状態 を詳細化観察する訳には行かない。しかし著者の撮影で

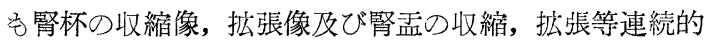
そ撮影したフイルムで認め, 更に尿管の腰部変曲等を認 める事が出来た。本法はレ線佒畫等と異り，1枚のフイ ルムそれ自身が routine のレ線フイルムそ同様に診断 的価值のあるものであつて 1 枚のフイルムを充分時間学 かけて検討する事が出来る・著者の行つた症例は僅か 17 例であつて症例も少く, 正常12腎について検討を加えた 炕とごめたが，高圧撮影法ば従来 IVP には不利である とされ殆しで利用されて来なかつたが，著者はこれを IVP に応用 し鮮明な腎杯, 腎孟及び尿管像の描出に成 功した. 従来の低圧直接撮影法と高圧間接撮影法とを比 較してみる己第 9 表の如くであり, 実用に充分供し得る ものと思われるが, 本法を以つて低圧直接撮影法に代え る訳に行かないが, routine のレ線腎盎像で病的陰影を 認めた時に, これを連続的に追及するのに大变役立つも のと考える.IVP が高圧間接撮法で行つて鮮明な筒杯, 腎盎及び尿管像定描出し得た事で害施が簡単で, 前処

第 9 表 低圧直接撮影法と高圧間接撮影法の比較

\begin{tabular}{|c|c|c|}
\hline & 低左直接腎㙉撮影法 & 高間接腎孟撮影法 \\
\hline 実施 & や>複雑 & 簡 単 \\
\hline 装置の移動 & 不可能 & 可 \\
\hline 管電圧 & $60 \mathrm{~K} \mathrm{~V} \sim 80 \mathrm{~K} V$ 低圧 & $115 \mathrm{~K} \mathrm{~V} \sim 120 \mathrm{~K} V$ 高圧 \\
\hline 造影剤量 & $\begin{array}{l}\mathrm{I} \mathrm{V} P \text { 成人 } 20 \mathrm{cc} \\
\mathrm{RP} \text { 成 } 5 \sim 10 \mathrm{cc}\end{array}$ & $\begin{array}{l}\text { I V P 成人 } 35 \sim 40 c c \\
\text { R P 成人 } 10 \mathrm{cc}\end{array}$ \\
\hline 撮影枚数 & $2 \sim 3$ 枚制限まり & 10 数枚制限なし \\
\hline 前処置 & 必 要 & 不必要 \\
\hline 压迫带 & 必 要 & 不必要 \\
\hline フイルム & 四ソ又は大陸 & $60 \times 60 \mathrm{~mm}$ 長尺判 \\
\hline 被曝線量 & 少 い & や>多い \\
\hline 骨陰影 & 消褪せず & 消褪する \\
\hline 腸内容 & 消褪せず & 消褪する \\
\hline $\begin{array}{l}\text { ユントラス } \\
\text { ト }\end{array}$ & 良 好 & 不 良 \\
\hline 腎杰像 & 鮮明, 平面的 & 鮮明, 立体的 \\
\hline בスト & 価 & 廉 価 \\
\hline
\end{tabular}

置, 圧迫帯の不要, 更に連続的に数枚撮影が出来て, し かも経済的である本法を(第 9 表),現在問題になつてい る高血圧患者を集めて，腎性高血圧を発見する検査法の 前段階として本法によりスクリーニングするのに今後役 立つものと思われる。

（3）逆行性腎孟間接撮影法：腎出血16例(左11例, 右 5 例),腎下垂症 $1($ 例（右 6 例，両側 4 例), 水腎症 4 例 （左 1 例，右 1 例及び両側 2 例）及び其の他 6 例（艄結 核の疑 2 例, 督結核 1 例及び尿路結石 3 例) の計 36 例に 本法を行つた。これらの中から代表的な症例を図示し， 正常と思われた右 8 腎, 左 7 腎の計15腎について撮影成 績定述べて来たが, 腎杯, 腎孟及び尿管の形態, 運動 等, 更に腎杯及び腎盘内に注入された造影訪の排泄時 間, 即与 Emptying time 等を更椫しく検討し, 腎出 血及び腎下垂症主主体にして若干の考按を述べる.

前処置：撮影にあたり下剤投与，食事制限及び浣腸 等の前処置を全例に施行しなかつた方読影に支障を来し たものは 1 例む無く, 静注性腎盂間接撮影像よりも更に 鮮明な腎孟像を得た。いずれにせよ高圧撮影ではか〉る 前処置は全く必要ないが, 腸内ガスの問題があり，乙れ を除去する工夫をすると一層好ましいレ線像を得る事が 出来るものと思う.

造影剂及び注入量： 造影剂は60\%ウロコリンM安 32 例に，75\%ウロコリン M定 4 例に使用してみた。得られ た腎盐像はかなり鮮明で両造影剂の間に汸造影上あまり 大きな差は認められなかつた。注入量は左右腎共に一般 に10ccを注入しんが, 注入時側腹部に緊張感を訴えて途 中で注入を中止したもので最少量 $2.5 \mathrm{cc}$, 逆に routine のレ線腎盎像で，腎杯及び謷㙉に拡張を認めたものでは 最大量の $20 \mathrm{cc}$ 注入した。乙の注入量に関して諸家の報 告があるが, 大体 $5 \mathrm{cc}$ 前後のようで, 注入時に大量の造

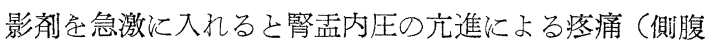
部痛)や造影剂の腎孟外組織への逆流，例えば Pyelotubular, Pyelolymphatic backflow 等が起り腎杯, 腎孟 の Emptying time等の検查が不能となる事があるので 注意する必要がある。

撮影体位，時間及び枚数：全て仰臥位で行つたもの 5 例，乙れは立位の所見と比較するために行つたもので ある・立位丈で行つたもの6例及び最初の1枚を仰卧 位で撮影し， 2 枚目から立位にして行つたもの 25 例で ある.このょうに仰臥位已立位已を同一症例で組合わ せて撮影を行つたのは，体位による謷杯，腎盎及び尿管 等の形態, 運動の変化や肯下垂の程度等を観察するため である. 又必要に応じて撮影台上で体位を斜位となし病 
的陰影を立体的に観察する事が出来た。撮影時間は全て 叫卧位又は立位で撮影する場合法造影剤注入終了直後に 1 枚撮影し, 次に尿管カテーテルを拔去して 30 秒間隔で 5 分迄11枚撮つて 8 分後にもう1枚撮影し計12枚の撮影 を行つた。仰卧位と立位の組合わせで行つたものでは仰 臥位で造影唷注入終了直後 1 枚撮影し, 造影永の流出を 防ぐ目的で尿管カテーテルは拔去しないで立位とし， 1 分後撮影台が立位になつた所でしれ学拔去して直ぐ 2 枚 目の撮影を行つて以後 30 秒間隔で 5 分迄 10 枚撮影し, 更 亿 6 分及び 8 分後々計 12 枚撮影した. 撮影枚数认最高で この12枚であるが, 被曝線量等を考慮に入れる己撮影枚 数忟なければ少い程良い。しかし撮影の性質上, 連続 的撮影澺義がある訳で 2 〜 枚の撮影では意味が無 い. 以上の事から著者の行つた撮影成績でこれらを検討 してみると，仰卧位丈で撮影する場合は造影郕注入終了 值後に 1 枚, 腎杯及び腎盂の排泄時間を見る目的で 3 分 後, 5 分後, 8 分後及び10分後の計 5 枚の撮影で充分で 西る. 全て立位の撮影では造影昘注入終了直後 1 枚, 1 分後, 3 分後, 5 分後及び 8 分後の計 5 枚の撮影で充分 目的を達し得る己思われ，仰卧位已立位の組合わせでは 立位丈の撮影の場合と同じく，計 5 枚の撮影で充分であ る. 本撮影裝置で 5 枚撮影すると被曝線量は $6.0 \mathrm{r}$ であ る.

腎孟腎杯への逆流現象己ほ一度造影された腎杯像が消 失し, 或る時期に再び現れて来る現象を云い病的所見で

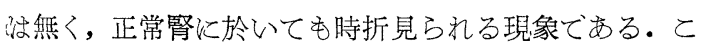

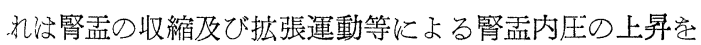
調節し, 腎蔵に対する安全弁的存在と一般に考えられて いるが，著者の例では右腎の正常な 8 腎中 2 珡にみら れ，2腎とも上腎杯に観察された。左腎の正常な 7 腎で 性中腎杯に 1 腎及られた. この現象と撮影体位との関係 を久てタる己, 右腎では 1 例が仰臥位で，他の1例は仰 㰾位と立位の組合わせで撮影した立位撮影像でみられ， 左㻉の1例は仰卧位撮影でみられた。このように起りに くいと思われる立位に於いてもみられる事から撮影体位 と活あま関係が無いように思われる。

腎杯及び腎盂の排泄時間, 即ち Emptying timeはレ 線像でてれらの陰影の消失によつて測定する事が出来る が, とれは腎孟内尿停滞を知るのに有效な検査法で, 腎 下垂時に於汀る尿排泄状態をこれによつて多く観察して いる.しかしこの排泄時間の測定は逆行性に造影剂を辢 孟内に加圧して注入する関係で, 腎孟内に刺戟が加わ わ, これに対する反応が起つてとの排泄時間で腎臓の生
理を強調する事は出来ないが，とれを検査する事は決し て無駄ではない.1921年 Goldstein ${ }^{39)}$ が初めて正常人に これを試み $3 \sim 7$ 分で腎盘内に注入された造影永は消失 すると述べ, $\mathrm{O}^{\prime}$ conor $^{40}$ は 6 ～8 分, 10分以上病的上 し, Dodson ${ }^{411}$ は 5 分で空虚となるが, 10分以上を病的 としている. 本邦では南 ${ }^{45}$ は 10 分以上病的とし, 森永 44)もや泣り10分以上を病的としている. しかしての Emptying time 它仰臥位, 立位時と分けてそれぞれ測定し ている報告は少く，須山早によると仰卧位 10 分以上，立 位 5 分以上を病的としている. 更にてれを各腎杯, 腎孟 別に分けて観察した報告は殆んぞ無い。腎臓坆腎杯, 腎 孟及び尿管へと収縮, 掘张運動を行つている訳で, 腎杯 己筲㙉の排泄時間をそれぞれ分けて各及検討する必要が 芯るように思われる。例え嘴孟内が完全に空虚となつ ているにひ拘らず，尚腎杯の一部が強く造影されている ような場合, これはその腎杯の運動機能の障害を疑わせ るもので，腎盖柱正常であつても良い訳である.そこで 著者は正常15腎でこれを腎杯, 腎孟別に仰臥位と立位で 比較検討を行つた。著者の例では第 6 表に見る如く, 全 て仰臥位で撮影した 5 例では上腎杯で 3 分〜 5 分, 中腎 杯で 2 分〜 3 分 30 秒, 下腎杯で $3 \sim 5$ 分及び腎㙉では 2

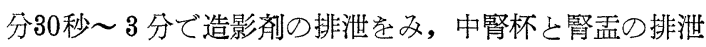
時間が上下腎杯のそれより幾分早いようである. 立位の 及で撮影した 2 例では上腎杯で 1 分 45 秒 2 分, 中腎杯 で 1 分〜 2 分 35 秒, 下腎杯で 3 分〜 3 分 30 秒及び腎孟で は 1 分〜 2 分 30 秒已仰臥位より早く, 最初の 1 枚怯仰卧 位で，2枚日より立位で撮影した 8 例では上腎杯で 1 分 $\sim 1$ 分 30 秒, 中腎杯で 2 分 3 分 30 秒, 下腎杯で 3 分〜 4 分及び腎㙉では 2 分〜 3 分であつた. 以上の成績から みて, これらの排泄時間は体位によりや>異り仰卧位で は正常の場合, 上腎杯 5 分以内, 中腎杯 4 分以内, 下腎杯 5 分以内及び腎㙉で 3 分以内と腎孟が一番早く, 次で中 腎杯及び上下靔杯の順である. 立位のみでは上腎杯 2 分 以内, 中腎杯 3 分以内, 下腎杯 4 分以内及び腎盕では 3 分以内已上腎杯が一番早く, 次で中腎杯, 腎㙉及び下腎 杯の順であつて仰卧位丈の場合より早く，仰臥位で 1 枚 撮影し 2 枚目より立位で行つた場合では, 上腎杯 2 分以 内, 中腎杯 4 分以内, 下腎杯 4 分以内及び腎孟では 3 分 以内己上腎杯がやほり一番早く, 次で腎盖, 中及び下腎 杯の順であつた。このように排泄時間は各腎杯によつて も異るし, 撮影体位, 造影敃の濃度, 注入量及び注入速 度等によつても影響される。

腎出血16例の腎杯, 腎盂の拕張の有無をみてみると第 
7 表に示す如く, 16例中11例 $(68.7 \%)$ にこれの拡張安 及，又立位撮影で腎下垂を認めたものが16例中 5 例（約 $31 \%)$ あつて, 右 3 例及び左 2 例で岁つた。 そしててれ らの下垂の程度も軽く，4例に下垂と同時に腎臓の横軸 备旋がみられた．更にこの下垂せる5例に尿管屈曲像が 観察された. 腎出血沙下垂, 尿管屈曲の結果, 腎盖内

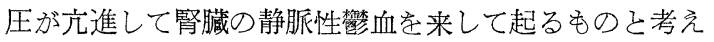
ている者もあるが, 決してその病因は一原的なものでは なく色々の要素が複蓶に作用し合つて筒出血が起るもの と思われる・次に腎盂腎杯への逆流現象についてみてみ ると，16例中 7 例（約43\%）にこれが観察された。との 現象と撮影体位との関係は仰臥位で 1 例 (下腎杯),立位 で 2 例 (上腎杯) 夜び仰臥位已立位の組合わせ撮影で 4 例（上腎杯 3 例，同一腎で上，中腎腎杯にみられたもの 1 例) であつた. 起りにくいと思われる立位で，しかも 上腎杯に多く観察された事は大变興味ある事である. してての現象は腎下垂や尿管屈曲像の認められた腎臟に は 1例もみられず，乙れらとは全く関係が無いように思

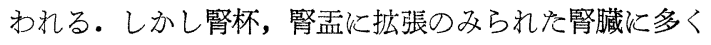
観察され, 本現象のみられた 7 例中 5 例に腎杯, 腎孟 の桩張がタられた. Narath 氏症状は16例中 7 例（約 43 \%)にみられ，亏ち5例は腎下垂のある症例にみ,他の 2 例は腎下垂は無いが，腎㙉の拡張のある症例に認められ た. 腎盂, 腎杯の Emptying time は全て立位で撮影し た 4 例では，上腎杯で 1 分 30 秒 5 分とかなり巾があ り, 中腎杯で 2 分〜 7 分, 下腎杯 3 分〜 8 分以上及び腎 盎では 4 分〜 8 分以上となり, かなり币がある. 仰臥位 己立位で撮影した 11 例では上腎杯で 1 分 30 秒 3 分, 中 腎杯で 2 分 30 秒 5 分, 下腎杯で 2 分 30 秒 8 分以上及 び腎㙉では 2 分〜 6 分とや>遅延がみられるが, Narath 氏症状があり，腎下垂の認められる場合に遅延する傾 向がある．全て仰臥位で撮影したものは 1 例であるが, それぞれ 2 分 30 秒, 3 分, 3 分 30 秒及び 3 分で全く正 常であつた. 即ち立位丈の撮影では上腎杯 5 分以内, 中腎杯 7 分以内, 下腎杯 8 分内外及び腎孟でも 8 分内外 そ延長をみ, 仰臥位已立位で撮影した11例では上腎杯 3 分以内, 中腎杯 5 分以内, 下腎杯 8 分内外及び腎孟では 6 分内外であつた. 以上述べた如く, 腎杯, 腎孟内に注 入された造影剂は大部分が立位では 5 分内外で消失する が第35図に示す如く 1 力所腎出血側に造影滆が点状に残 る部位が認められ, この点状陰影は他の腎杯, 腎盂像が すでに消失しているにも拘らず，最後の 8 分後像に至る フイルムにも認められた. か>る所見を呈したものは16
例中 3 例で，乙れの本態治尚不明であるが，大変興味尔 る所見と思われる。著者は腎出血16例について検討した 所見を述べて来たが，結局本症に特異的な所見注得られ なかつたが第 7 表に見る如く, 本症では整孟，腎杯系に 拡張像の認められるものが比較的多く $(68.7 \%)$, 次て 腎孟撉杯への逆流現象 $(43.7 \%)$, Narath 氏症状 $(43.7$ \%),腎下垂 $(31.2 \%)$ 攻び尿管屈曲 $(31.2 \%)$ の順でと れらの所見が観察された。 又腎杯, 腎盖の排泄時間は, 上及び中腎杯で正常範囲内のものが多く, 下腎杯及び腎 孟でや〉遅延している.乙れの遅延は腎杯, 腎盂に拡張 があり, Narath 氏症状の認められたもので多く及られ た.とれらの所見は腎出血の結果亦, それともこれが腎 出血の原因となつたのかは判らないが, 少くとも出血腎 に损いては腎杯，腎㙉及び尿管に異常陰影を認めるもの があつた。腎下垂症14腎について腎杯, 腎盂の拡張の有 烸をみてみると，拡張のあるもの14腎中10腎 $(71.4 \%)$ であつた.

腎臓の下垂度であるが, これに関しては1936年 Bird-

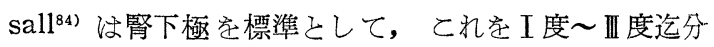
けている. 即ちI度とは立位でレントゲン学的に第腰 椎の上縁迄下るもの, 第IV腰椎の上縁迄下るものを II 度 とし，第 $\mathrm{V}$ 腰椎の上縁迄下るものを III度としている. 同 年 Woodruff \& Sherer ${ }^{85)}$ は腎盎の中心標準として 立位で第 III 腰椎に下るもの第 I 度, 第 IV 腰椎迄を第 II 度, 第 $\mathrm{V}$ 腰椎迄或はこれ以下に下るものを第度として いる. 本邦では 1953年清水 ${ }^{86)}$ は腎盂の下極を基準とし て第IV腰椎上下縁以内のものを II 度, これょり軽いもの を I 度,高度のものをIII度とした. 著者の例をWoodruff \& Sherer の分類に従つてみてみると， III度のもの14 腎中 4 腎, II 度のもの 4 腎及びI度のもの 6 腎であづ

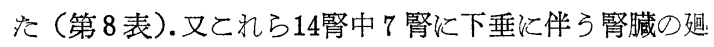
旋が観察された。尿管の屈曲牥14腎全例にみられ，乙れ 沙腎臓の下垂状態が強く, しかも腎蔵の迴旋が伴う症例 に強く現れる傾向にある. 腎盖腎杯への逆流現象は14腎 中 3 腎に及られ，部位は上腎杯で 2 例及び中腎杯で 1 例， で，体位が立位にも拘らず腎出血の症例 こ同じょうに 上,中腎杯で 観察された。Narath 氏症状は14腎中 9 腎 (64.2\%) にみられ高濃度造影戍が 緊張の低下した腎 盖, 腎杯の下方に沈及尿已造影剂との境に汇けた水平状 の境界線を形成して，これがレ線腎盂像に見られる所見 であるが, 腎臓の下垂の程度の強いもの, 下腎杯及び腎 孟排泄時間の延長しているものに多く現れている. 警 杯, 腎孟の拡張と Narath 氏症状 との関係をみてみる と, これらの拡張している10腎中 6 腎にこの症状を認妙 
第 1 図

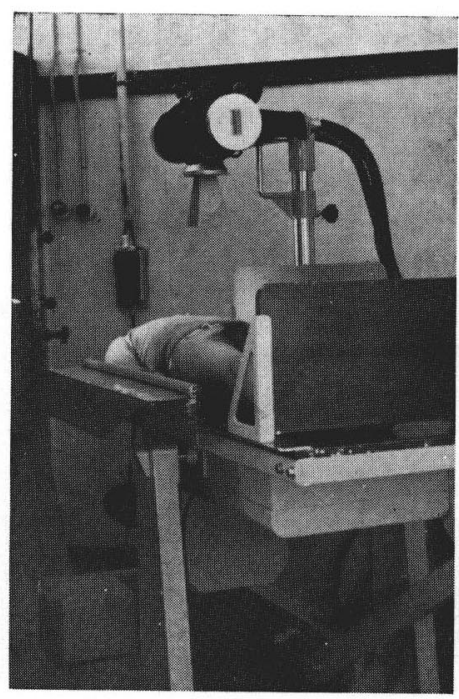

第 2 図

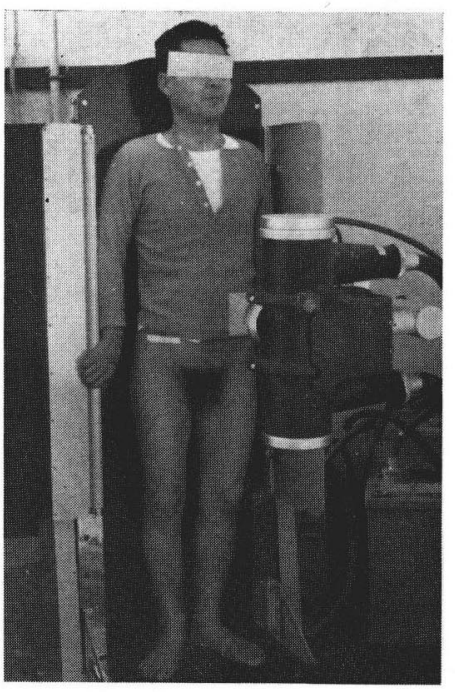

第 3 図
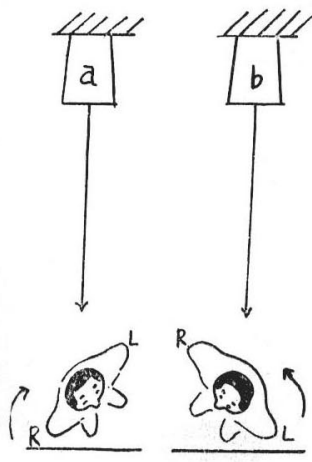

$\mathrm{a}$ ：第 I 斜位

c : 第 III 斜位

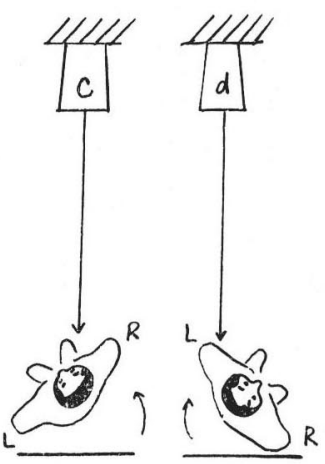

b : 第 II 斜位

$\mathrm{d}$ : 第 IV 斜位
第 4 図（高圧間接像）仰臥位

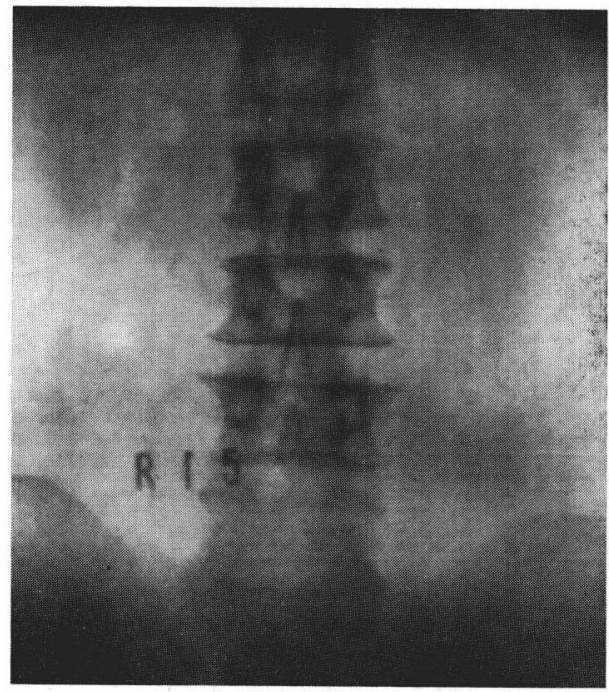

第 5 図（低压直接像）仰臥位

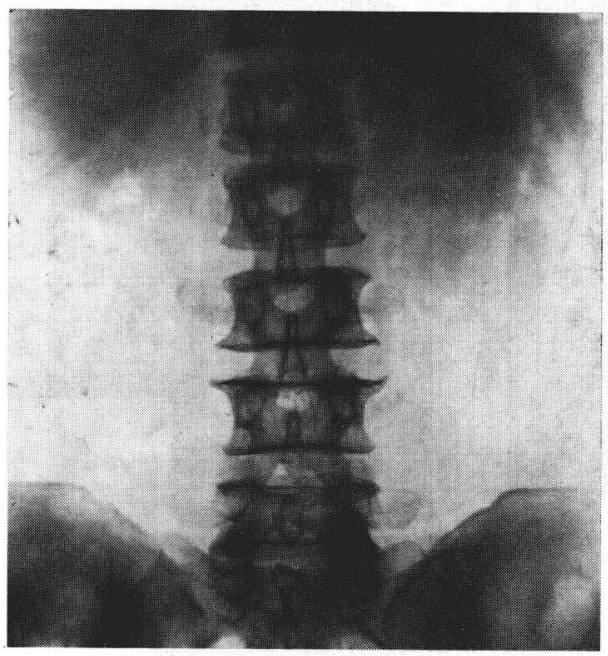

第 6 図 右腎結石（仰臥位）

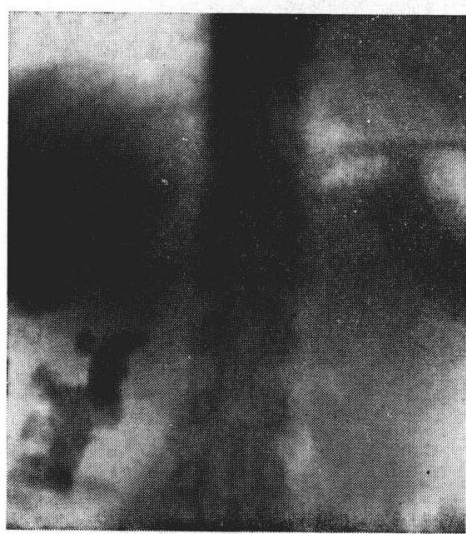

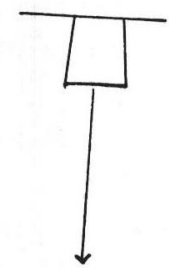

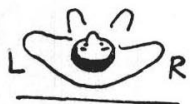


第 7 図（第 $V$ 斜位 $60^{\circ}$ ）
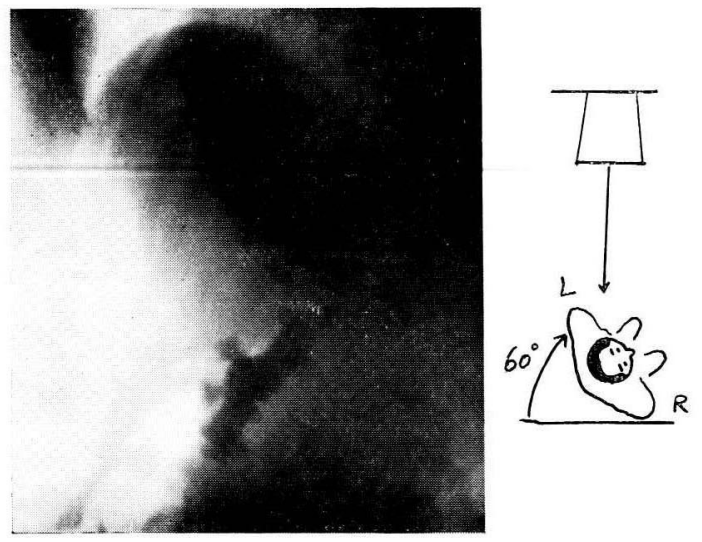

第 8 図（第 I 斜位 $150^{\circ}$ )
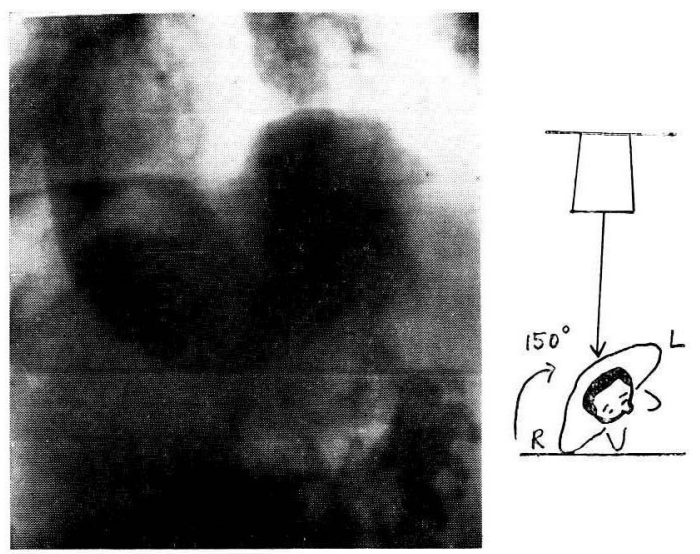

第 9 図腹膜後腔気体撮影

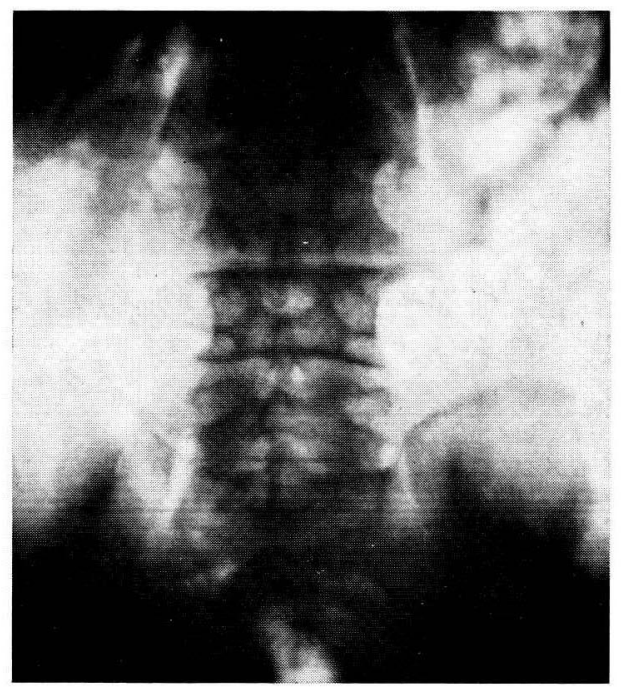

第10网正常例（I V P)，5 分後（仰卧位）

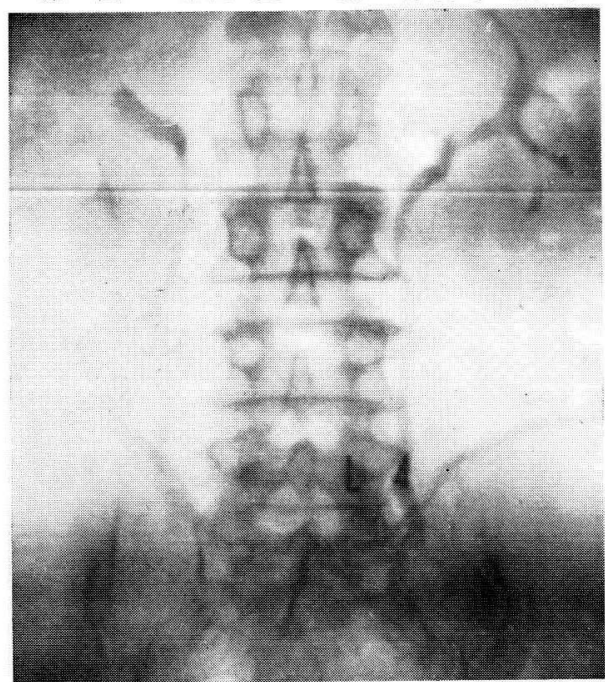

第11咸 7 分後（仰臥位）

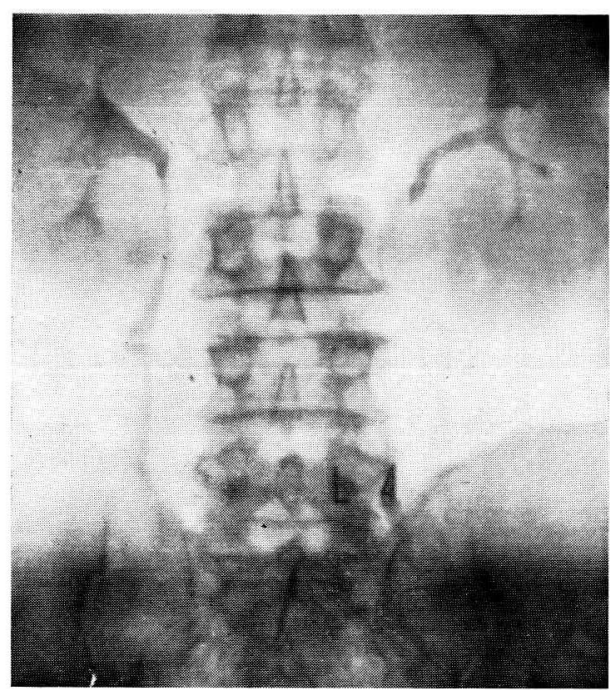

第12図20分後（仰卧位）

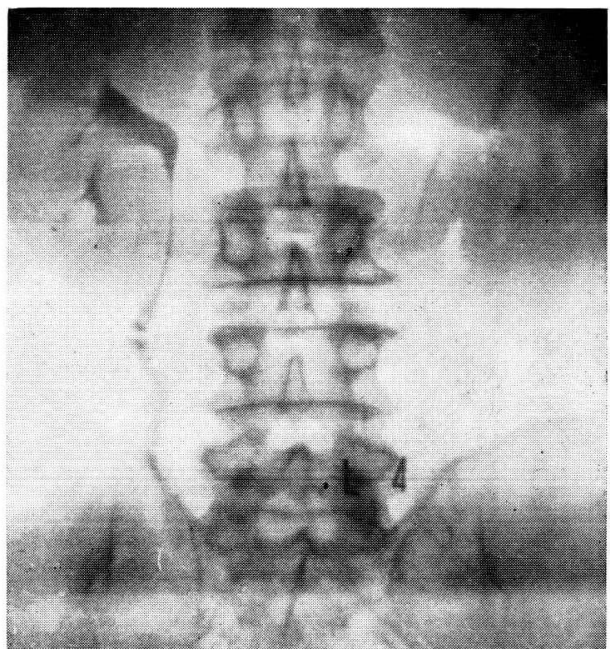


第13図左腎結核の疑 5 分後（仰臥位）

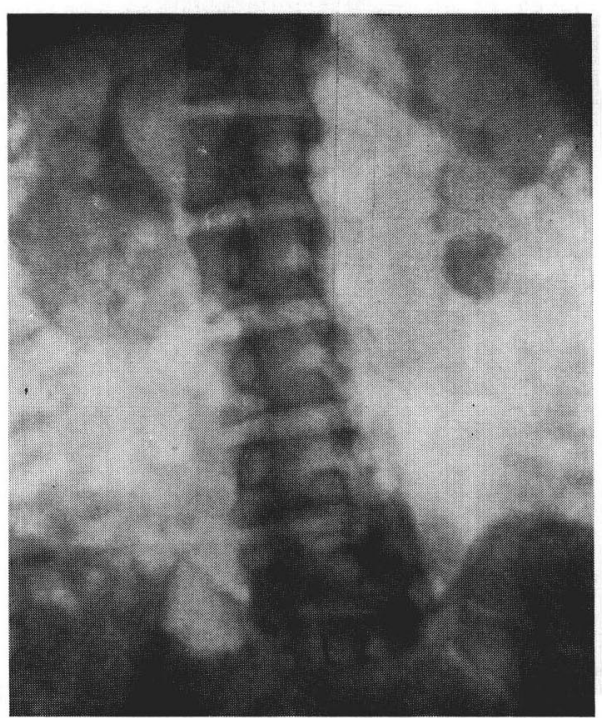

第14図 7 分後 (第 II 斜位 $30^{\circ}$ )
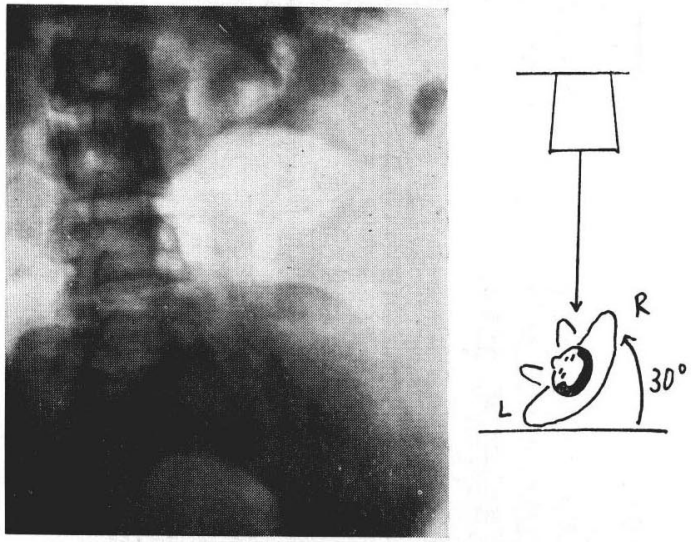

第 15 図 10 分後（第 III 斜位 $60^{\circ}$ ）

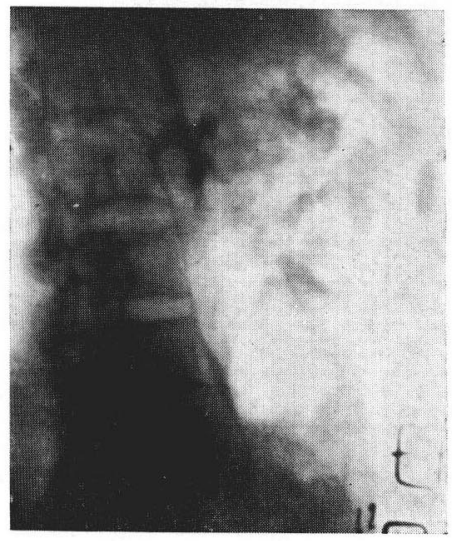

第16図 右腰部腎变位 3 分後（仰臥位）
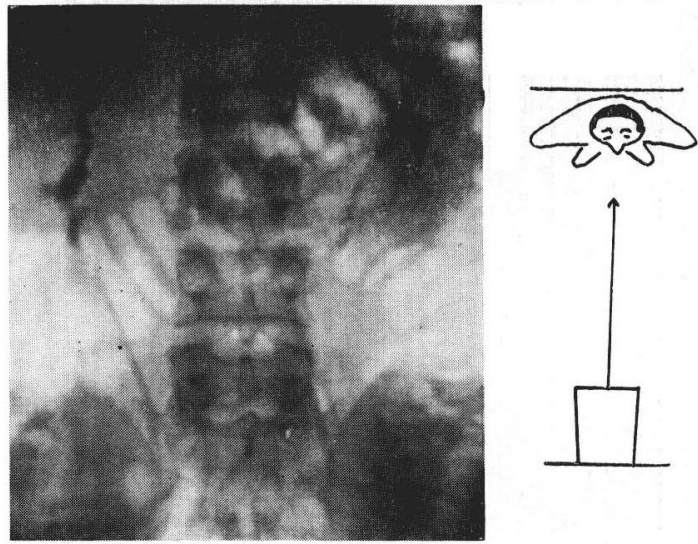

第17図 11 分後（第 $\mathrm{I}$ 斜位 $30^{\circ}$ 立位）

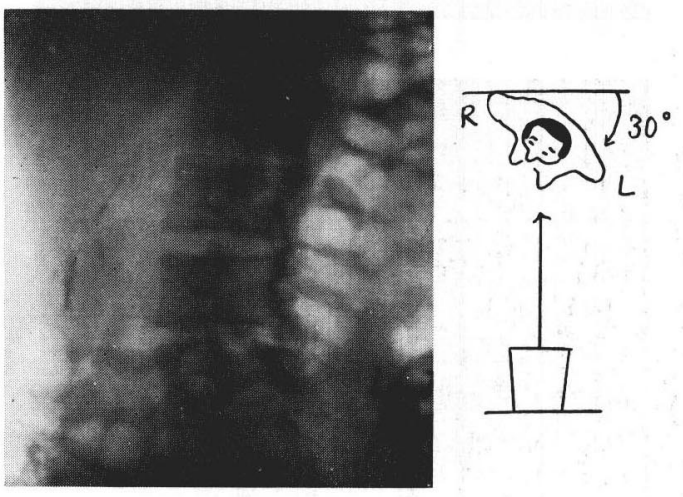

第18図腎孟腎炎10分後（低圧直接像）（仰臥位）

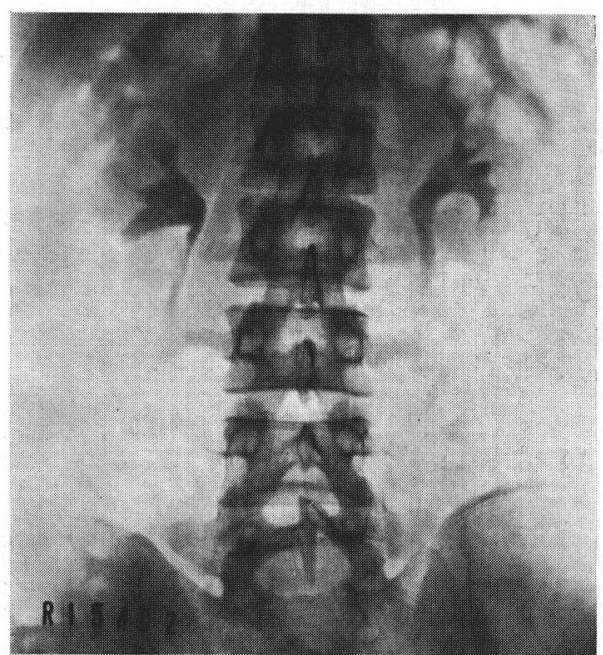


第19四 静注: 終了直後（仰卧位）

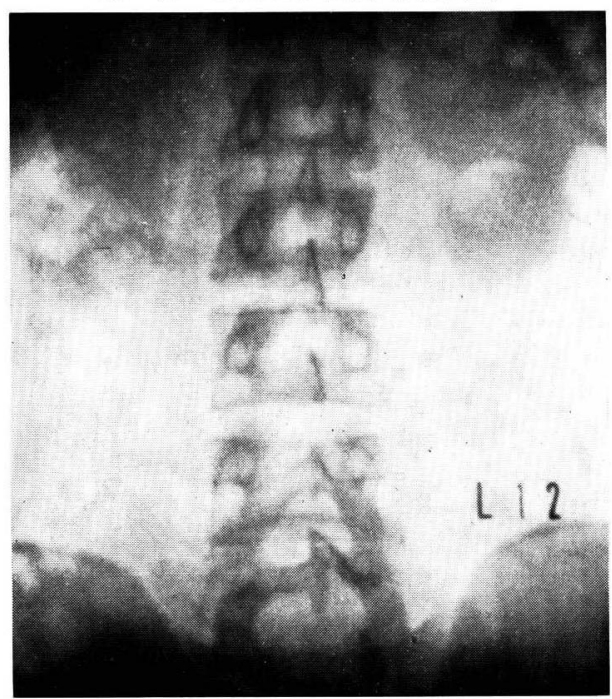

第20図 5 分後（仰卧位）

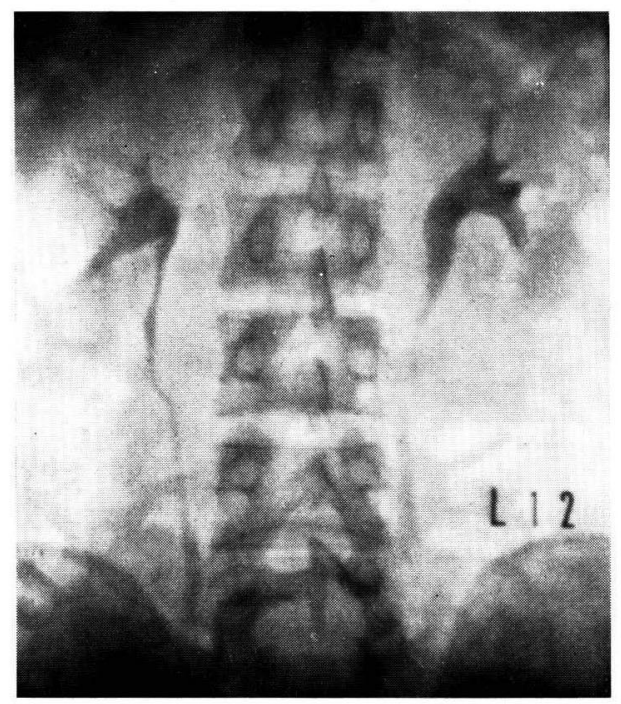

第21戍 7 分後（仰卧位）

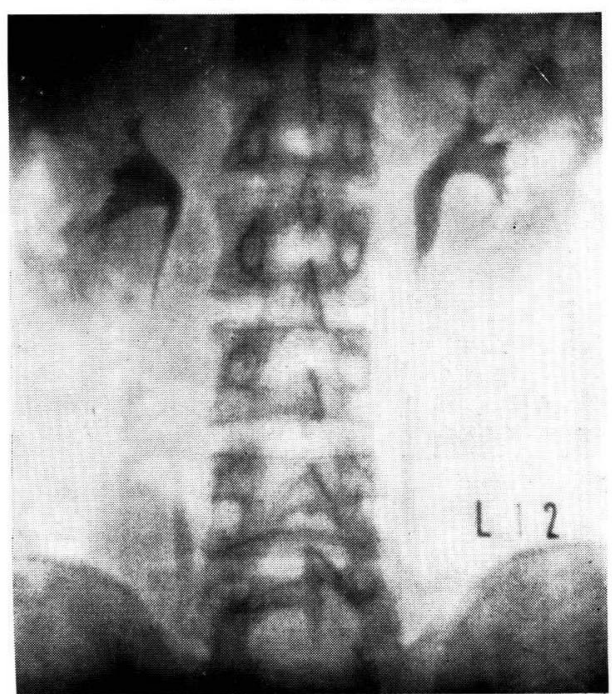

第22网 9 分後(仰倠位)

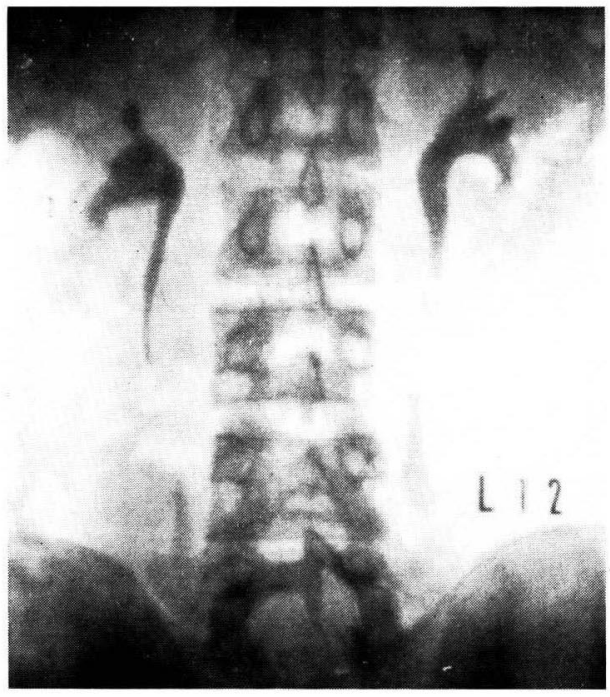

第23困 11分後（立位）

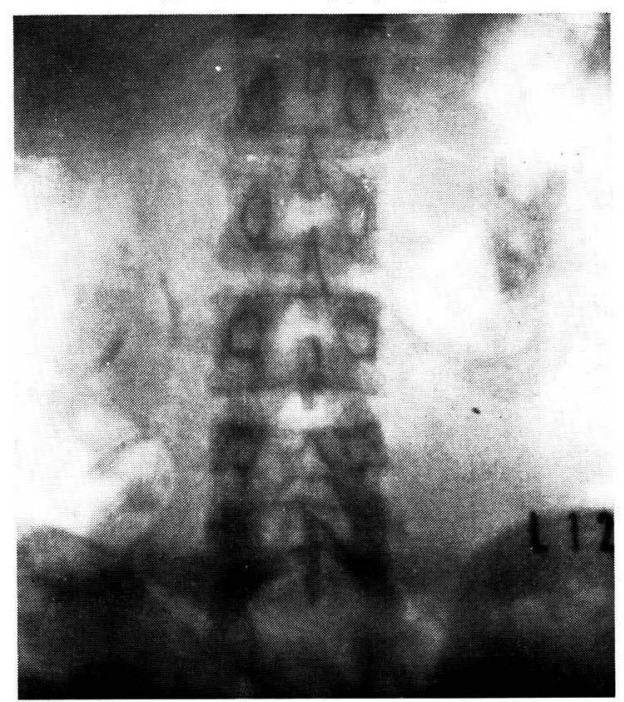

第24成起立性㕅㐫消失例15分後（仰卧位）

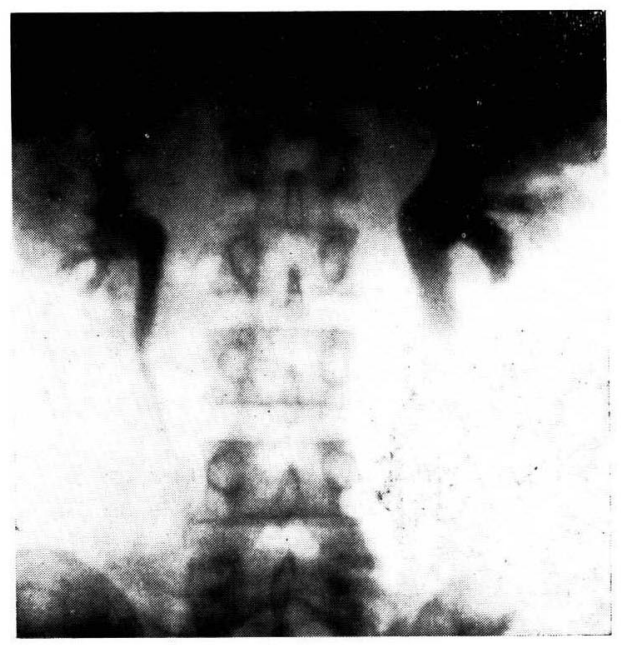



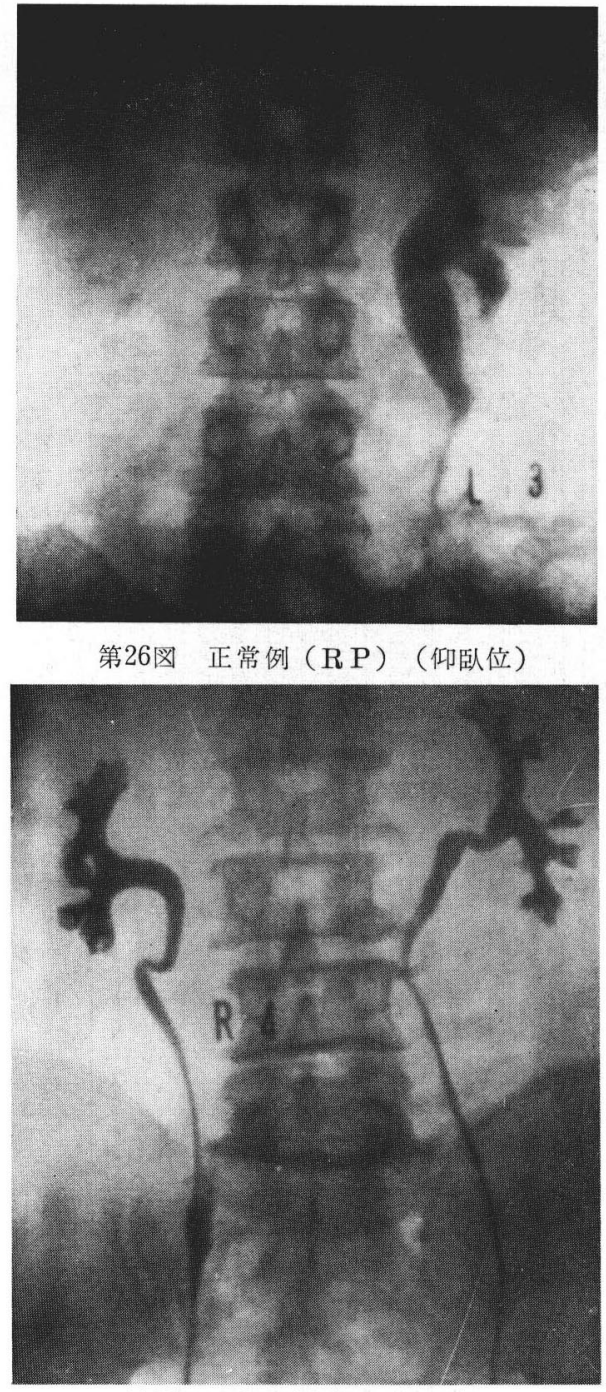

第27図 2 分 30 秒後（立位）
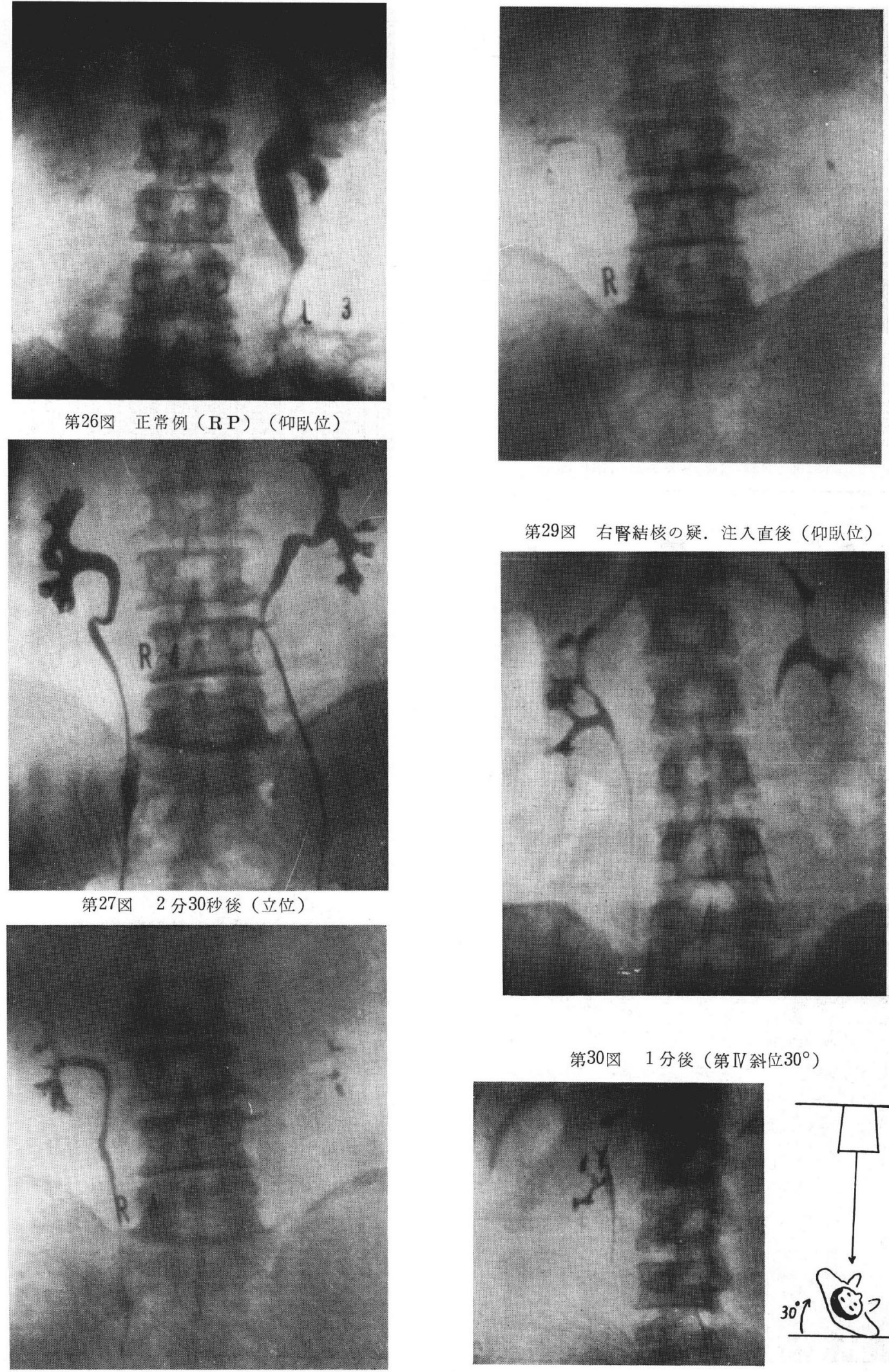

第29図右腎結㤥の疑，注入直後（仰臥位）

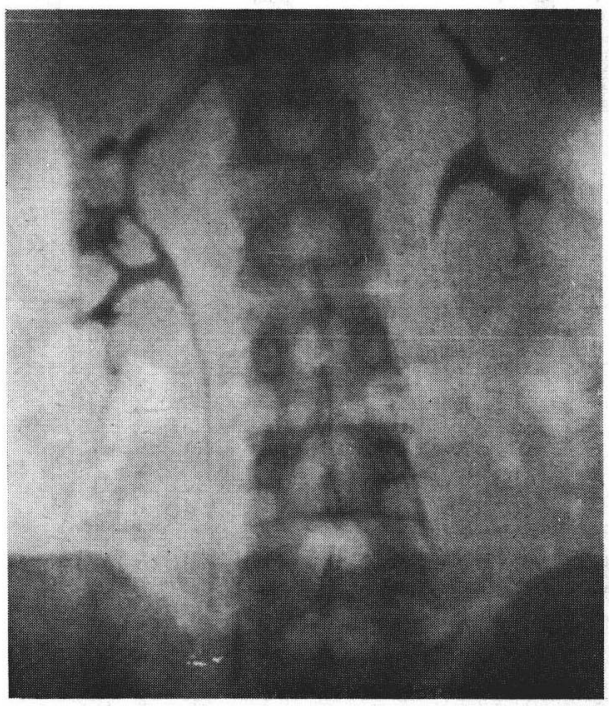

第30図 1 分後（第 $\mathbb{I}$ 斜位 $30^{\circ}$ )
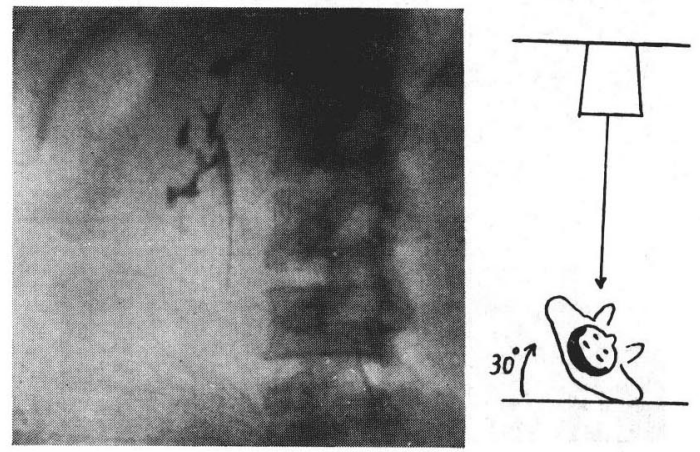
第31図 4 分後（第 $\mathrm{V}$ 愈位 $60^{\circ}$ )
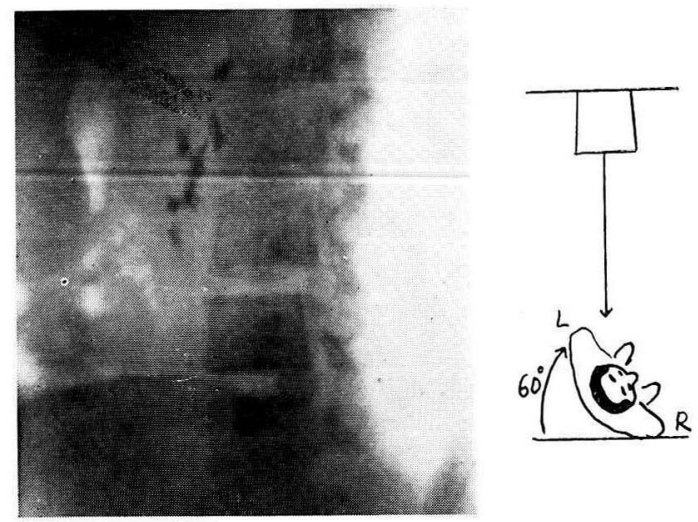

第32図腎孟腎杯への逆流現像の図

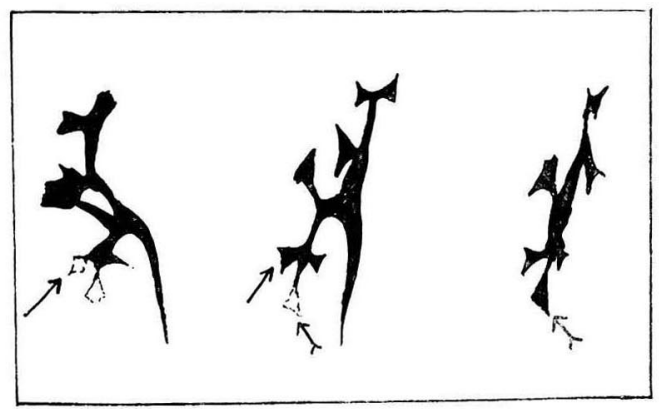

第33図左腎出血. 注大直後（仰卧位）

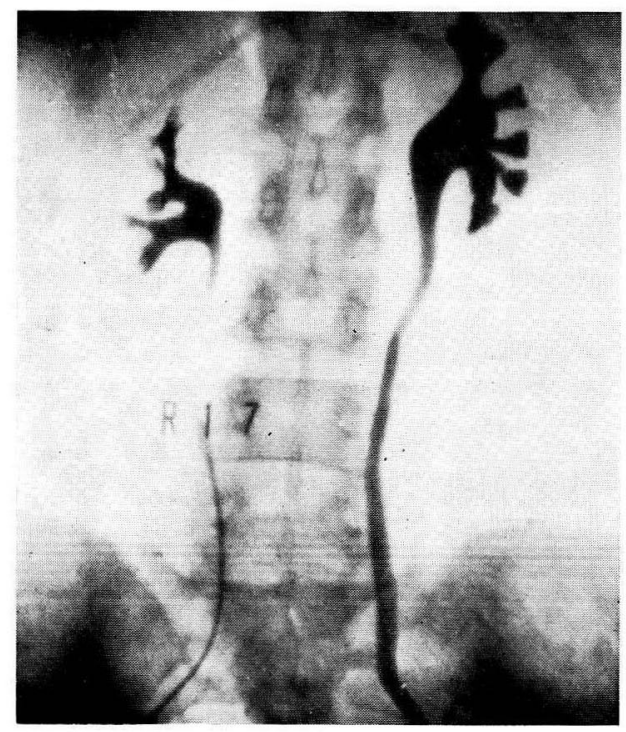

第34戍 1 分後（立位）
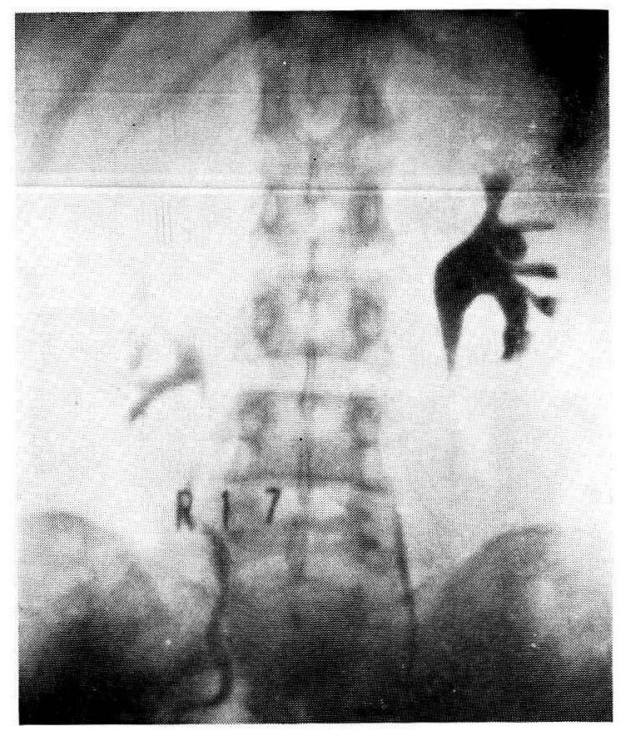

第35図 8 分後（立位）

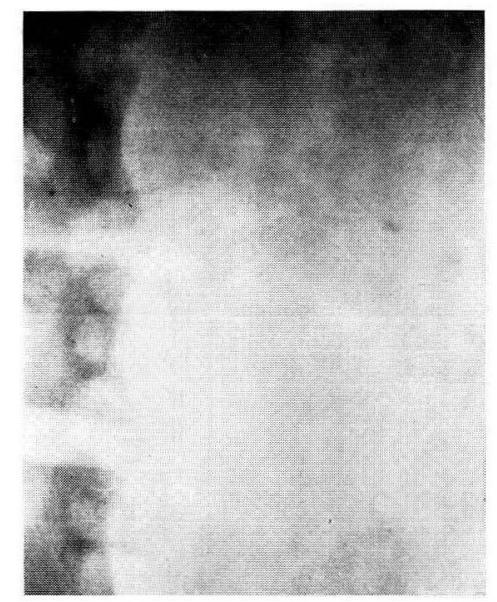

第36図腹部単純像（仰欩位）

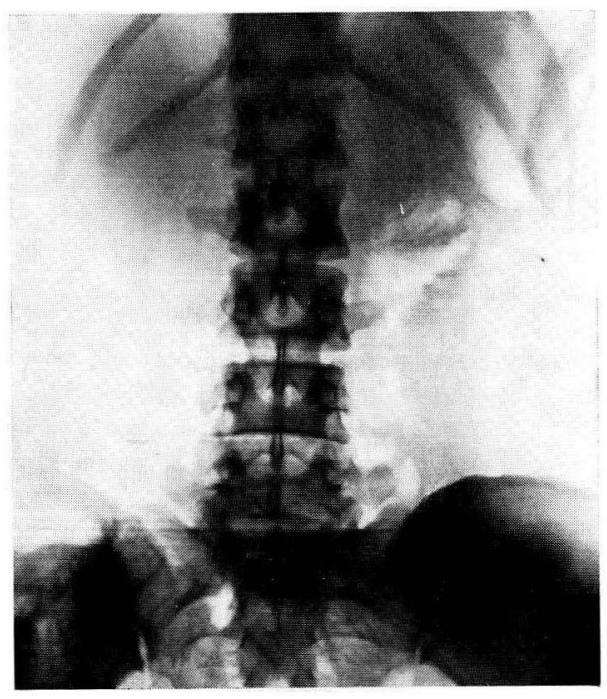


第37図両側水腎昰. 注大直後（仰臥位）

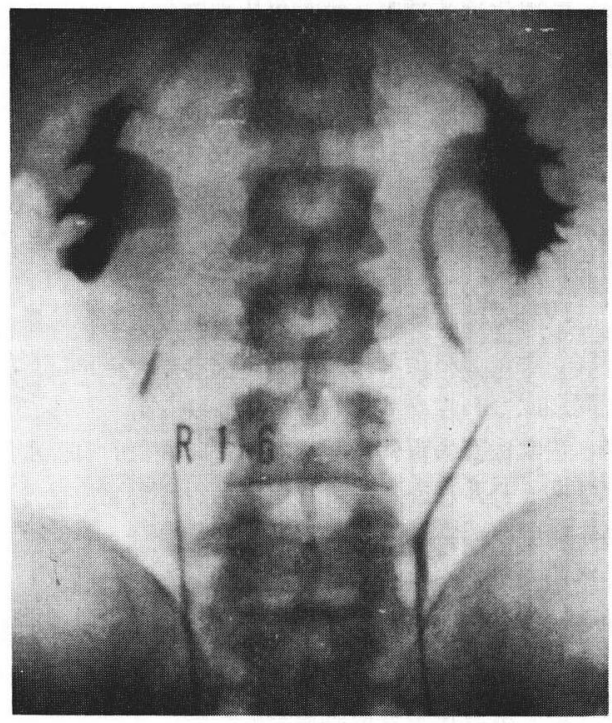

第38図 1 分後（立位）

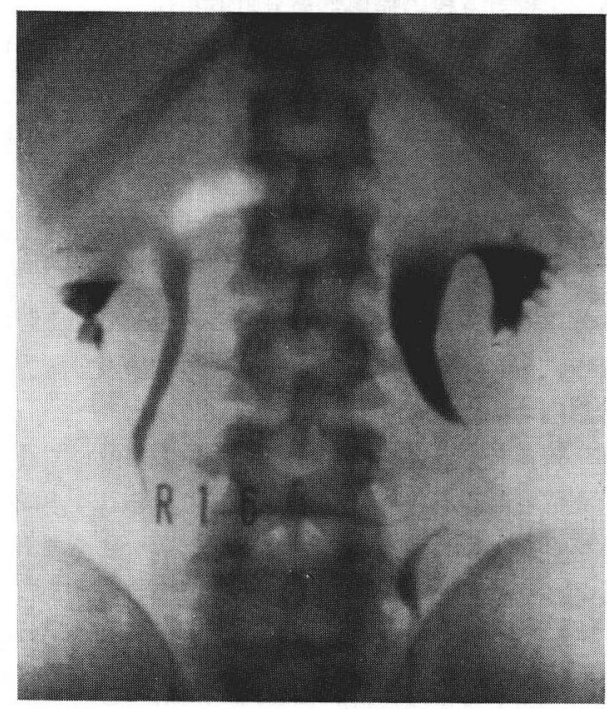

たが腎杯，腎盂に全く抎張像のみられなかつた 3 腎にも この症状が微察された。次に腎下垂症14腎の腎杯，腎孟 の排泄時間であるが，第 8 表にみる如く，上腎杯で最短 1 分 30 秒, 最長 8 分以上とかなり巾があるが大体 2 分〜 4 分で, 中腎杯で最短 2 分 30 秒, 最長 15 分で大体 3 分 6 分, 下腎杯で最短 2 分 30 秒, 最長 15 分以上で大体 4 分 ～ 8 分及び腎孟では最短 2 分 30 秒, 最長 15 分以上て大体

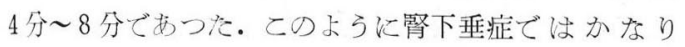

第39図 3 分30秒後（立位）

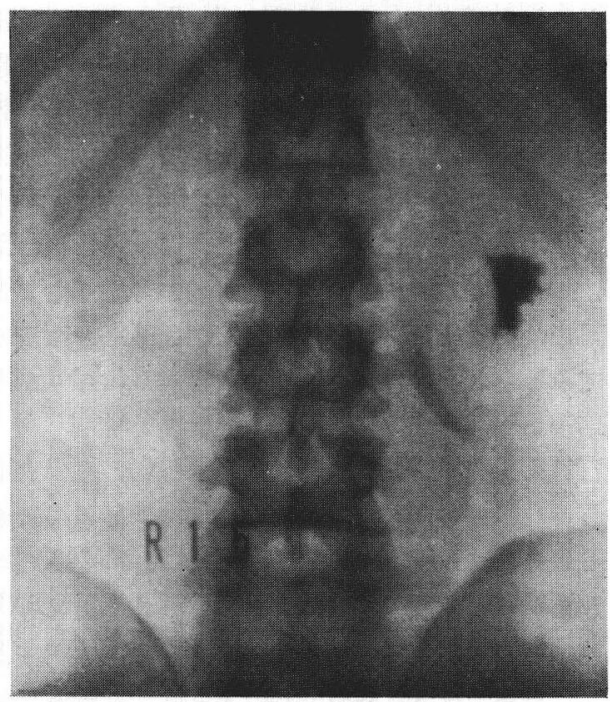

第40図 8 分後（立位）

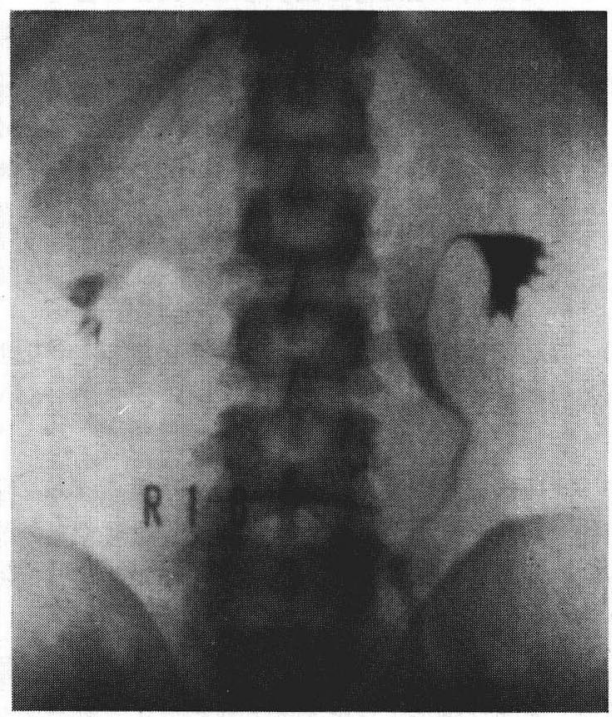

Emptying time の延長をみる.しかし延長沈している ものの造影剂の排泄は上，中及び下殽杯の順に行われて いる事を観察した. 以上の事から Emptying timeの

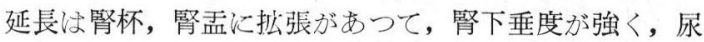
管屈曲が著明でしかも Narath 氏症状のみられる症例 で多くみられた。腎下垂症の㛑杯，腎跙の Emptying time の特徵こして, 第 8 表にみる如く上腎杯及び中腎杯 の排泄時間はあまり遅延せず，下腎杯及び腎盂のそれが 
遅延する傾向にある．腎下垂症のうちこの排泄時間の遅 延がどの位の頻度にあるかと云えば，Rehn ${ }^{87)}$ の靔固定 術を施行した62例中17例 $(27.4 \%)$ にみられ，南は遊走 腎者20例で10分以上残つていたものは14例 (70\%) あっ たと報告し，1962年森永は 10 分以上を病的として 42 例中 26 例の $61.9 \%$ に遅延をみている.著著の10例14腎では立 位 5 分以上を病的とすると, 病的なのは上腎杯で14腎中 2 腎, 中腎杯で 3 腎, 下腎杯で 9 腎及び腎孟でも 9 需と

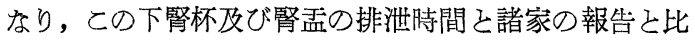
較してみると著者の例では14腎中 9 腎 $(64.2 \%)$ で排泄 遅延がみられた。

逆行性腎孟間接撮影法を高圧撮影で行い，充分実用に 供し得るレ線撮影に成功したが，RP は下部尿路に通過 障害等があれば尿管カテーテルの拆入は 不可能であつ て, 又感染等の危険性むあり, 患者往える負担も大き い. しかし IVP は写真の鮮明度は RP に比較する己 劣るが，腎臓や尿管に機械的刺戟も与えず，腎臟及び尿 管の生理を自然の状態で観察するのに最も理想的な撮影 法であつて多数の集団を検查する場合に好都合である. ホ〉る意味に於いて IVP に高圧間接影法を危用し鮮明 なレ線腎冏像の描出に成功した事は意義が大きいものと 思われる。本撮影法はあく迄も従来のレ線撮影代るも のでは笎く, routine のレ線写真で病的陰影を認めた場 合, これを詳細に追及するに注大変役立つものと信ず る.

\section{VII 結 論}

1）高圧間接撮影法を上部尿路撮影飞試みた。即与腹 部単純撮影法10例, IVP 17例及 び RP 36例の計63例に 試みた。

2）高圧撮影法は撮影時間の短緶，小焦点管球の使用 が可能である。従つて撮影時間の短縮は被曝線量の軽減 に有利であり, 小焦点管球の使用は鮮明な畫像を期待し 得る.

3）フイルムは $60 \times 60 \mathrm{~mm}$ 長尺判で 10 数枚の連続的撮影 が可能である. 従つてフイルムの枚数にあまり制限が無 く経済的である。

4）高圧撮影のため下剂投与，食事制限及び浣晹等の 前処置の必要佂無 $<$, 障害陰影である11 12肋骨陰影及 び推体の横突起等が消裉して読影に好都合である.

5）被曝線量は最高に撮影した12枚で14.4r で，との 線量では殆んご問題にならないが, 必要以上に撮影枚数 各増すべきではない。

6）腹部単純撮影法に高圧間接撮影法は不利である.
しかし腹膜後腔気体撮影法には有利と思われる。

て）撮影体位第 I～第IV嵞位に变换し，Сれを立位 又は仰臥位で行つて腎臓の鋳型結石の形態観察や，腎 杯，腎孟の病的陰影を分析した。

8) IVP 行従来高圧撮影は不利であるとされていた が, 撮影裝置の改善, 光学機械の発達及び高濃度血管造 影訪の出現心で充分実用に供し得るレ線腎孟像の描出に 成功した。

a) IVPでは造影剂は主に85\%ウロコリンM $\mathrm{M}$ な2 25〜40 CC 静注した。造影剂静注によるアレルギー性副作厈は殆 んご問題にならなかつた。

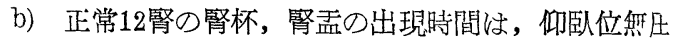
迫で 2 ３分, しかし 5 分後になると腎杯, 腎㙉及び尿 管像は鮮明に現れて来る.11分後立位にすると腎臓に起 立性反応が起り急激に腎杯，腎盖像の消失をみる。

c) IVP の撮影時間及び枚数ね，仰卧位のみで撮影 する場合, 造影剂静注終了後 1 分, 5 分, 9 分及び15分 の計 4 枚，仰臥位と立位の組合せでは，1 分，5 分及び 9 分後迄を仰卧位で撮影し, 11分後立位で, 更に15分後 にもう1枚計 5 枚の撮影で充分目的を達し得る。

d) 正常腎孟の型は解部学的腎孟定認め, 腎孟より 2 〜 3 の大腎杯が分れ，比較的分岐度の高いものが多い，

9） RP では IVP に比較してより一層鮮明な腎杯, 腎孟及び尿管像を描出し得た。

a）正常腎の腎杯，腎孟排泄時間は，仰臥位で上腎杯 5 分以内, 中腎杯 4 分以内, 下謷杯 5 分以内及び腎搵で は 3 分以内である．仰臥位と立位の組合せでは上腎杯 2 分以内, 中腎杯 4 分以内, 下腎杯 4 分以内及び腎孟では 3 分以内であつた。

b）腎盖腎杯への逆流晲象は仰臥位及び立位で钼察さ れ，立位でしかも上腎杯に比較的多くみられた事は興味 ある事で，撮影体位さはあまり関係が䒜いようである。 そしてこれは腎出血例に比較的多く観察された。

c）腎出血例では需杯，腎孟に搪張をみるものが比較 的多 $<, 68.7 \%$ 々ら机, 次で 腎侖腎杯への逆流現象 (43.7\%),Narath 氏症状 (43.7\%), 腎下垂 $(31.2 \%)$ 及び尿管屈曲 $(31.2 \%)$ の順にて记らの所見が観察され た.

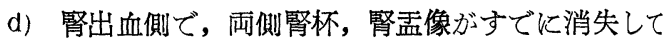
いるにも拘らず, 最後の 8 分後撮影に至るフイルム迄 1 力所造影剂が腎臟の出血側に点状陰影として残る所があ る.これの本態は尚不明なるが，てのような興味ある所 見を16例の腎出血者中 3 例に認められた。 
e) 腎下垂症の腎杯, 腎孟の排泄時間々, 上, 中腎杯 では正常範囲に近いものが多く, 下腎杯及び腎孟のそれ がかなり延長しているものが多い。

f）腎下垂症で尿管屆曲が全例敒認めろ，次で腎 杯,腎盘江搪張のあるもの $71.4 \%$, Narath 氏症状(64.2 \%),腎下垂に伴う腎廻旋 $(50 \%)$ 及び腎孟腎杯への逆流 現象 $(21.4 \%)$ の順にこれらの所見が観察された.

10）IVP が高圧間接撮影法で成功した事は routineの レ線腎孟像で病的陰影を認めた場合, これ簡単でしか も患者にあまり負担を加ないで追及するのに今後充分 役立つものと思われる。

稿を終るに臨み, 終始御指導, 御校閲を賜つた恩師高 安久雄教授, 並びに佐藤昭太郎教授に深甚なる謝意を表 します. 更に又本研究に際して御指導, 御協力下された 本学放射線科教室野崎秀英教授, 並びに放射線科教室に 深く感謝の意を表する次第であります。

本研究は昭和 36 年度文部省科学研究費の援助を受けた ものである。

\section{VIII 主要交献}

1) 後藤薰: 日本泌尿器科全書, 第 1 巻, 192頁, レントゲン検査，金原出版及び南江堂，東京， 昭和 36 .

2) 江藤秀雄, 粟冠正利, 倉光一郎, 梅垣洋一郎, 田坂棰 : 放射線医学, 医学書院, 東京, 昭和 34 .

3）古賀良彥：日放射線医会誌，5, 122, 1937.

4) Manoel de Abreu: Radiol., 33, 363, 1939.

5) 三矢辰雄, 田村栄樹 : 日泌尿会誌，27，266, 1938.

6）高安久雄, 西浦常雄 : 日泌尿会誌, 45, 159, 1954.

7）岡直友, 後藤武: 日泌尿会誌, $47,740,1956$.

8）浅井順：日泌尿会誌，48, 789, 1957.

9）須山敬二：日泌尿会誌， $52 ， 463,1961$.

10）後藤薰, 仁平寬已, 酒徳治三郎, 片村永樹, 女 吉唯夫, 北山太一, 沢西謙次, 蛭多量令, 中川 隆, 高橋陽一, 本郷美彌, 久世益治 : 泌尿紀要, 7, 823, 1961.

11) Weber, E.: Fortschr. Röntgenstr., 32, 585, 1924.

12) Zacker, F.: Fortschr. Röntgenstr., 33, 251, 1925.

13) Stephani, J.: J. de radiol. et d'èlectrol., 13, $393,1929$.

14）江藤秀雄 : 日本臨床, 13, 147, 1955 .

15）野崎秀英, 沢田豊, 古屋儀郎, 山崎岐男 : 綜合 臨床, 10, 379, 1961 .

16）暒田一之：日泌尿会誌，50, 504, 1959.

17）藤井浩：日泌尿会誌， $47,740,1956$.
18）河崎屋三郎, 福村亮 : 臨皮泌誌, 11, 256, 1957.

19) Kaufman, J.J., Schanche, A.F. and Maxwell, M.H.: J. Urol., 89, 498, 1963.

20）岡直友, 菅野英男, 塚本俊雄: 臨放, 7, 230, 1962.

21) Sigel, A.: Urologe., 1, 196, 1962.

22) Wilson, M.C., Wilson, C.L., Mendelsohn, E. A. and Crow, N.E.: J. Urol., 87, 1010, 1962.

23）堀慶久：日医放会誌，19, 1882, 1959.

24) Roach and Wigh: 堀慶久による.

25) 牛田隆雄：日泌尿会誌, 51, 229, 1960.

26) Bodner, H., Howard, A.H. and Kaplan, J.H.: J. Urol., 79, 356, 1958.

27) Lusted, L.B. and Miller, E.R.: J. Roentgenol. \& Rad. Therap., 75, 56, 1956.

28) Überall, R.: Urol. int., 13, 230, 1962.

29) Amar, A.D.: J. Urol., 89, 506, 1963.

30）山之内秀三：皮泌誌，31，1358，1931.

31）張惺庵：日泌尿会誌, 23, 443, 1934.

32）仁平寬己: 泌尿紀要, $3,665,1957$.

33) Narath, P.A.: J. Urol., 43, 145, 1940.

34) Jona, J.L. \& Flecker, H.: Surg. Gynec. \& Obst., 51, 50, 1930.

35) Alken, C.E. u. Büschner, H.K.: Zschr. Urol., 46, 801, 1953.

36) Maintz, M., Meese, J. \& Wüllenweber, G.: Zschr. Urol., 32, 682, 1938.

37）山口圭造: 日外会誌, 34,883 , 昭和 8 .

38) Catel, W. \& Garsche, R.: Fortschr. Röntgenstr., 86, 66, 1957.

39) Goldstein, A.E.: J. Urol., 6, 125, 1921.

40) O'conor, V.J.: Arch. Surg., 18, 1263, 1929.

41) Dodson, A.I.: Urological Surgery, C.V. Mosby Co., 227, 1950.

42) Peirson, E.L.J.: New England J.M., 201, 568, 1929.

43) Lowsley, O.S. \& Kirwin, T.J.: Clinical Urology., III Ed., Williams and Wilkins. Co., $838,1956$.

44）森永圭一郎：日泌尿会誌，53，28，1962.

45) 南武: 日本泌尿器科全畫, 2 巻 2,449 頁, 遊走 腎症, 金原出版及び南江堂, 東京, 昭和 36 .

46）林大八郎 : 泌尿紀要, 8, 176, 1962.

47) 高橋明 : 皮泌誌, 39, 794, 1936.

48) MacMahon, H.E. and Latorraca, R.: J. Urol., 71, 667, 1954.

49) Pytel, A.: J. Urol., 83, 783, 1960.

50）清水圭三 : 外科の領域, $5,711,1957$.

51）仁平寛己：日泌尿会誌， 54, 446, 1963.

52) Spitzer, W.M.: J.A.M.A., 63, 2110, 1914.

53) Hunner: Zschr. Urol. Chir., 35, 210, 1930. 
54) Thelen, A. u. Wiegers, H.: Arch. Klin. Chir., 277, 547, 1954.

$55 ）$ 佐藤忠敏：名医学, 78, 5, 41, 1959.

56）清水圭三 : 日本泌尿器科全書， 2 卷 $1 ， 374$ 頁, 特発性腎出血，金原出版及び南江堂，東京，昭 和 35 .

57) Sharpe, A.R., Jr., Fox, P.G., Jr. and Dodson, A.I., Sr.: J. Urol., 81, 780, 1959.

58）渡辺一郎：皮泌誌，39，784, 1936.

59）北川正惊：皮泌誌，39, 800, 1936.

60 ）志賀亮：皮泌誌，39，806, 1936.

61) Voelcker und Lichtenberg.: 南武による.

62）Fenwick：清水圭三（泌尿紀要，6,741, 1960) による。

63) Reich: 吉川康史（名医学, $70,838,1955$ ) に 上る.

64) Thomas, B.A.: J. Urol., 22, 603, 1929.

65) Gottlieb, J.G.: Zschr. Urol., 27, 363, 1933.

66）井尻辰之助：皮泌誌，20，906, 1920.

67）佐谷有吉：皮泌誌, 21, 264, 1921.

68）清水圭三 : 日泌尿会誌， 26, 851, 1937.

69) 吉川康史 : 名医学, $70,838,1955$.

70 ）大越正秋, 斎藤豊一, 岩村貢 : 日泌尿会誌, 47 ,
$741,1956$.

71）清水圭三 : 泌尿紀要, 6, 741, 1960.

72) Gondos, B.: Radiol., 74, 19, 1960

73) Gondos, B.: Radiol., 76, 615, 1961

74) Narath, P.A.: 日泌尿会誌， 51，849, 1960.

75) Hutter, K.: Zschr. Urol. Chir., 30, 256, 1930.

76) Hajos, E.: Zschr. Urol., 55, 137, 1962.

77) 吉村克俊：内科, 8, 8, 1961 .

78）野崎秀英：診々療，47,846, 1959.

79）入江英雄，村上晃一：綜合臨床，12,247, 1963 。

80）高橋信次：X線撮影と検查の手びき, 311頁, 南山堂, 東京, 昭和 36 .

81）土屋交雄, 天谷博：診々療，47，915, 1959 。

82 ）三矢英輔，浅井順，牛田隆雄，須山敬二，三宅 弘治，細江謙三：日泌尿会誌，50，649, 1959 。

83) Fergusson, J.D.: Brit. J. Urol., 32, 484, 1960.

84) Birdsall, J.C.: J. Urol., 35, 135, 1936.

85) Woodruff, S.R. \& Sherer, R.G.: J. Urol., 35, 125, 1936.

86）清水圭三：日泌尿会誌， $44 ， 313,1953$ 。

87) Rehn, J.: Zschr. Urol., 53, 1,1960. （昭和38年10月 21 日受付，特別揭載） 